\title{
CELl CyCle PHASE Of NONDIVIDING CELLS IN AGING HUMAN CELL CULTURES DETERMINED BY DNA CONTENT AND CHROMOSOMAL CONSTITUTION
}

Rosalind Marie Yanishevsky

(Ph, D. Thesis)

June 6, 1975

Prepared for U.S. Energy Research \& Development

Administration under contract No. W-7405-Eng-48

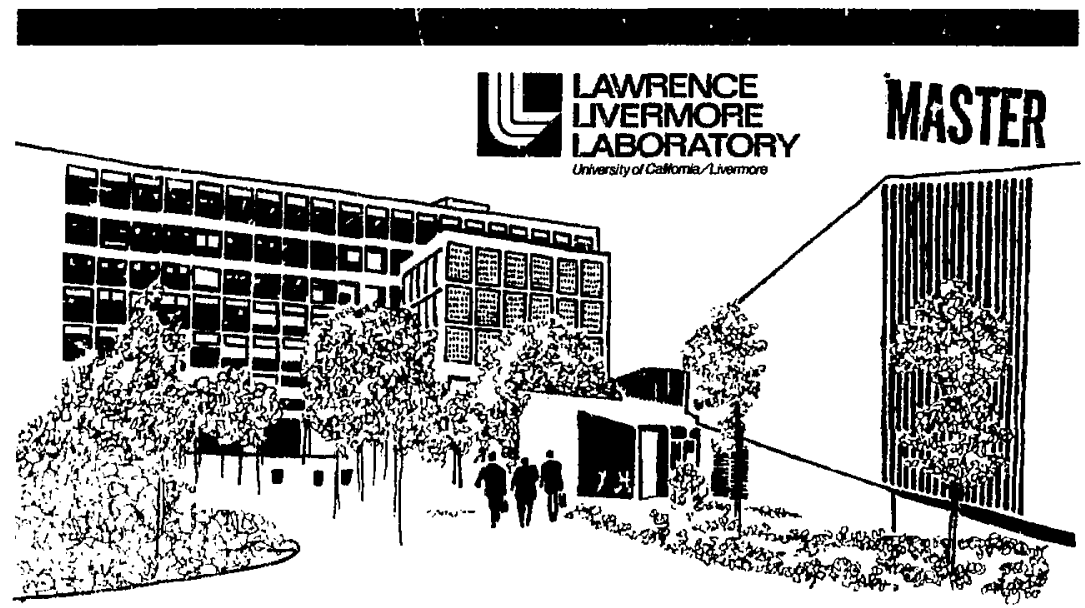


NOTICE

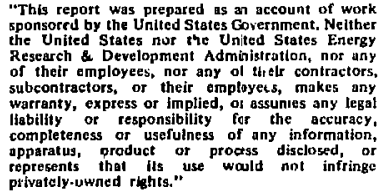

pilvately.uwned rights."

Printed in the United States of America

Available frcm

National Technical Information Service

U.S. Department of Commerce 5285 Port Royal Road

Springfield, Virginia 22151

Price: Printed Copy \$ "; Microfiche $\$ 2.25$

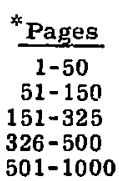

NTIS

Selling Price

$\$ 4.00$

$\$ 5.45$

$\$ 7.60$

$\$ 10.60$

$\$ 13,60$ 


\section{CELL CYCLE PHASE OF NONDIVIDING CELIS \\ IN A.GING HUMAN CELL CULTURES DETERMINED \\ Rosalind Marie Yanishevsky \\ Vincent J. Cristofalo \\ Mortimer [., Mendelsohn}

BY DNA CONTENT AND CHROMOSOMAL CONSTITUTION

Нumar diploid cell cultures, strain WI-38, have a finite proliferative capacity and have been proposed as a model of biological aging. These cultures possess a subpopulation of nondividing (or out-of-cycle) cells that with culture age increases exponentially relative to the dividing cells. These studies involve the identification of the phase of the cell cycle wherein nondividing cells lose their ability to divide.

To identify the cell cycle phase of the nondividing cells, cultures of various ages sere exposed to ${ }^{3} \mathrm{HdT}$ for 48 hours to label dividing cells, then the c/cle phase was identified for individual cells ty one of two method:. Ind finally, the proliferative status of the same cells was scorid by autoradiographic evidence of ${ }^{3}$ HdT uptake. The methods to identify the cycle phase were (1) determination of DNA stain content by Feulgen scanning cytophotometry, and (2) determination of chromosome constitution by the technique of premature chromosone condensation (PCC).

Preliminary experiments showed the effect of continuous exposure to various levels of ${ }^{3}$ HdT on celi growth. High levels of ${ }^{3}$ HdT 
inhibited cell cycle traverse: the cell number and labeling index curves reached a plateau; the cell volume increased; the cells acrumulated with 4C DNA contents and it appeared that they blocked in $G_{2}$ phase. This pattern is consistent with a radiation effect. Cytophotometric-autoradiographic experiments showed that the majority of nondividing (unlabeled) cells had 2C DNA contents (where $C$ is the haploid DNA content), and therefore were arrested in the diploid $G_{1}$ phase. Increasing culture age was associated with increasing numbers of nondividing $4 \mathrm{C}$ cells. These cells could be arrested as diploid in $G_{2}$. Alternatively, they could be arrested as tetraploid $G_{1}$, since increasing culture age was associated with the appearance of proliferating polyploid (8C) cells. Finally, the results suggested that the $2 \mathrm{C}$ and $4 \mathrm{C}$ cells for older cultures had an increased dispersion of DNA values than for younger cultures. This could be due to aneuploid DNA content, which may cause cell arrest. Other cytophotometric-autoradiographic experiments utilized double labeling to identify $S$ phase cells and thus permitted a quantitative evaluation of the dispersion [i.e., calculation of the coefficient of variation (CV)] of DNA values. If aneuploid DNA content caused cell arrest the $C V$ would be greater for old cells than for young cells, and for nondividing cells than for dividing cells. The results showed that the $C V$ of DNA values for $2 C$ and $4 C$ cells increased with age, and, in general, that the CV was similar for dividing and nondividing cells. Thus, aneuploid DNA content is 
associated with aging. In addition, it appears that there is not a causal relationship for measurable aneuploid DNA content and cell arrest.

The chromosomes of nondividing WI-38 cells were examined by fusing senescent cultures with mitotic Hela cells to induce PCC. Nondividing cells condensed their chronatin to form PCC as readily as dividing cells. The efficiency of PCC was independent of cell cycle phase, as shown by comparison of observed frequencies with expected frequencies. Ninety-six percent of the nondividing cells had single chromatids and were therefore in $G_{1}$. The remaining $4 \%$ had anomalous chromatid pairing. Typical $\mathrm{G}_{2}$ configurations (double chromatids) were observed only among dividing cells. These data indicate that nondividing cells with $4 \mathrm{C}$ DNA contents shown in the cytophotometricautoradiographic experiments are arrested in tetraploid $\mathrm{G}_{1}$ phase. 


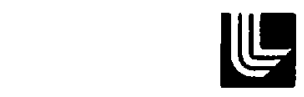

\section{LAMRENCE LNEFMOFE LABORATOFY}

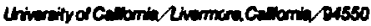

\section{UCRL -51840 \\ CELL CYCLE PHASE OF NONDIVIDING CELLS \\ IN AGING HUMAN CELL CULTURES DETERMINED \\ BY DNA CONTENT AND CHROMOSOMAL CONSTITUTION}

Rosalind Mario Yanishevsky

(Ph. D. Thesis)

June 6, 1975 


\section{DEDICATION}

\section{I}

\section{TO MY TEACHERS}

who took what was given

who gave what could not be taker.

Idries Shah

"Tales of the Dervishes" 


\section{ACKNOWLEDGEMENTS}

There are many teachers who have holped me in a myriad of rays. Ny parents continually inspire me by the examples of their lives. Doctors Vincent $C r$ istofalo and Mortimer Mendelsohn have taught me the scientific p rocess from their individual vantage points. Their insight, critical advice and encouragement helped me crystallize the ideas presented in this dissertation. Among my other teachers I trank Dr. Inthony Carrano for his enthusiastic support and active interest; Dr. Brian Mayall for many stimulating and enjoyable discussions; lee Thorn who has helped me to synchesize and organize my thaughts; memlers of the histar Institute, especially Doctors David Kritchevsky and George Rothblat for their personal understanding and guidance; members of the Biomedica! Division of the Lawrence Livern. 're Laboratory, especially our resourceful library staff, Dr. Dan Moore, II for his lielp with statistical analyses and, in particular, Sylvia Crooker for her skill and perseverence in typing this manuscript. I thank all these people for their friendship.

This work was supported by the following rants: NCI 2 Ro1 CAl4533, NIH 2 RO1 Gim20291, HD-027:1 and HD-06323. 


\section{INDEX}

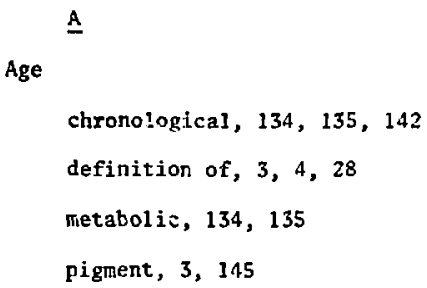


CHo cells, 9, 10, 23, 76, 77

Chromososies

abcrrations, 102,117, 118, 143

anomalous, $83,96,127,129,145$

cell cycle, and (see Premature chromosome condensation)

number, 76,77

premature chromosome condensation, (see Prenature shromosome condensation)

Colcemid, 22, 23, 24, 77, 83, 124

Coefficient of variation, 17, $32,33,70,72,102,111,115,122,123$

defirition, 27

Coulter volume (see Cell vosume)

CYDAC, $11,15,28,67,73$

Cytophatometry

DNA, 11-15, 18, 21

theory, 13, 14

$\underline{\text { D }}$

Density-dependent inhibition, 35, 102

Deoxyribonucleic acid (see DNA)

Differentiated cells, 1, 136

Distributional Error, 14

DNA

areuploid DNA content (see Areuploid DNA content)

content, in the cell cycle, $0.17,30,66,76$ 
dispersion of DNA content, 32, 33, 65, 70, 97, 99, 100, 107, 114,

$$
117,122,123
$$

fibre autoradiography (see Autoradiography, DNA fibre)

hyperdiploid DNA content, 66,69

hypodiploid DNA content, 69, 118, 119

synthesis, $1,2,4$

$\underline{\mathbf{E}}$

Endoreduplication, 113, 128

Error theory, 141-144

F

Feulgen

cytochemistry, 11, 12

staining, $12,13,18$

Filters

interference, 13

Fusion, 6, 7, 22-25, 77

monolayer, 24,25

suspension, 25,77

$\underline{G}$

$G_{1}$-blocked cells, $4,5,32,110$

$G_{2}$-blocked cells, 4, 5, 32, 59, 99, 109, 110, 113, 126, 127, 137

$\mathrm{G}_{0} \operatorname{cells,2,138}$

G $\operatorname{ce} 11 \mathrm{~s}$

identification of $6,7,17,22,34$ 


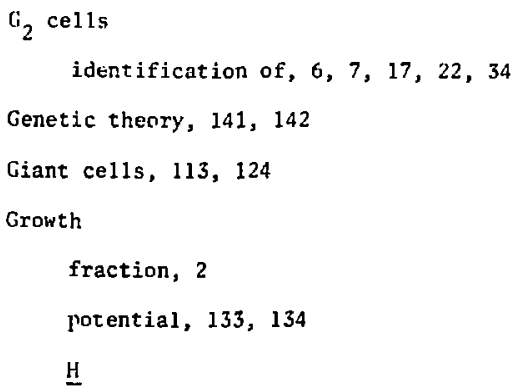

$M$

Micronuclei, 117, 119, 122

Mitotic

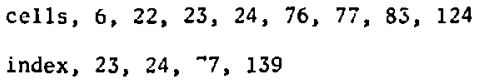


viit

$$
\begin{aligned}
& \text { nonreversible, } 2,105 \\
& \text { reversible, } 2,102
\end{aligned}
$$

Nonproliferating cells (see Nondividing cells)

Nuclear blebs, 119, 122

$\underline{\mathbf{P}}$

PCC (see Premature Chromosome Condensation)

PDL

definition, 63,66

Ploidy level, 7, 8, 22, 62, 76, 125

Polyploid cel1s, 31, 32, 66, 69, 76, 83, 97, 105, 113, 116, 123-125, 145

Premature aging (see Progerie and Werner's syndrome)

Premature chromosome condensation, $6,7,8,22,23,25,26,75-97$,

\section{$125-127$}

Progeria, 130, 131

Prophasing, 6

Q

Qn cells, 105

Qr cells, 102

Quiescent cells (see Nondividing cells)

R

Radiation

calculation of dose, 112, 150, 151

effects of, 44, 62, 108, 110,112, 124, 125, 143 
$\quad \begin{aligned} & \mathbf{S} \\ & \text { S cells }\end{aligned}$
$\quad$ identification of $4,6,7,17,19,22,26,32-34,66,69,115$

Senescence

programmed, $1.41,142,144$

random, 141-144

Shake-synchrony, 23, 76

Slides

cleaning, 20

preparation methods, $18,20,21,25,63,65,94,101,114,119$

Staining

Feulgen (see Feulgen staining)

metachromatic, 7

Steady state, 136

Stem ce11s, 136, 137, 138

I

T cells, 132

Thymidine

concentration, 109, 150, 151

$5_{\text {HdT }, 3}$

Tissues

expanding, 135,138

renewing, 135, 136, 137

static, $135,138,140$ 
$\underline{\mathrm{U}}$

Unbalanced growth, 44, 59, 62

$\underline{V}$

Virus

herpes-type, 129

replication of in old cells, 144

Sendai, 24, 25

$\mathrm{SV}_{40}, 130,133$

Volume (see Cell volume)

w

Werner's syndrome, 130 
TABLE OF CONTENTS

Page

DEDTCATION. ............................... ii

ACKNOWLEDGEMENTS $\ldots \ldots \ldots \ldots \ldots \ldots \ldots \ldots \ldots \ldots \ldots \ldots \ldots \ldots \ldots \ldots \ldots \ldots$

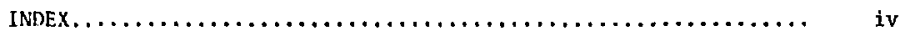

TABLE OF CONTENTS $\ldots \ldots \ldots \ldots \ldots \ldots \ldots \ldots \ldots \ldots \ldots \ldots \ldots \ldots \ldots \ldots \ldots$

LIST OF FIGURES AND TABLES $\ldots \ldots \ldots \ldots \ldots \ldots \ldots \ldots \ldots \ldots \ldots \ldots \ldots \ldots$

BIBLIOCRAPHY $\ldots \ldots \ldots \ldots \ldots \ldots \ldots \ldots \ldots \ldots \ldots \ldots \ldots \ldots \ldots \ldots \ldots \ldots \ldots \ldots \ldots$

PREFACE $\ldots \ldots \ldots \ldots \ldots \ldots \ldots \ldots \ldots \ldots \ldots \ldots \ldots \ldots \ldots \ldots \ldots \ldots \ldots \ldots \ldots \ldots \ldots \ldots$

INTRODUCTION. ................................. 1

MATERIALS AND METHOdS.......................... 9

A. General Maintenance of Cell Cultures............... 9

B. DNA Cytophotometry......................... 11

1. Feulgen cytochemistry.................... 11

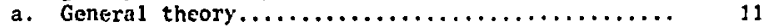

b. Staining recipes...................... 12

2. Juanning cytophotometry.................. 1 .5

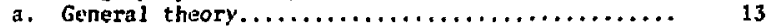

b. CrDAC instrumentation.................. 15

C. Cytophotometric-Autoradiographic Studies............ 16

1. Section I procedire....................... 17

a. Cell cultivation and labeling.............. 17

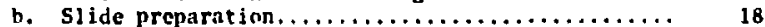

c. DNA cytophotometry.................... 18

d. Autoradiography...................... 18

2. Section II procedure....................... 19

a. Cell cultivatiog and latbeling............. 19

(1) Effect of Hat on $\mathrm{ki}-3 \mathrm{~s}$ cell growth........ 19

(2) Double labeling with Illat..............

b. Slide proparntion......................

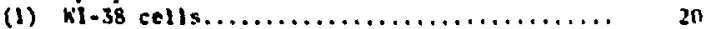

(\$) White blood cell standaril.............

c. DNA cytophotometry.................... 21

d. Nutoradbugraphy $\ldots \ldots \ldots \ldots \ldots \ldots \ldots \ldots \ldots \ldots \ldots \ldots \ldots, 21$ 
D. Premature Chromosome Condensation-Autoradiographic

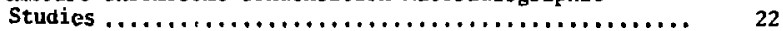

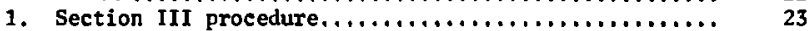

a. Cell cultivation and labeling............... 23

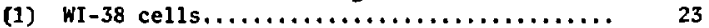

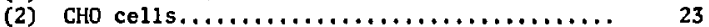

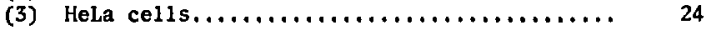

b. Cell fusion............................ 24

(1) Fusion in monolayer................. 24

(2) Fusion in suspension................. 25

c. Slide preparation and chromosome identification.. 25

d. Autoradiography........................ 26

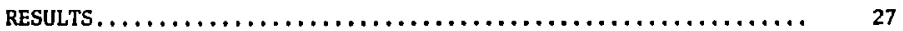

A. Cytophotometric-Autoradiographic Studies............ 27

1. Section I............................... 27

a. DNA distribution of dividing and nondividing

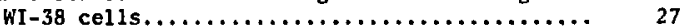

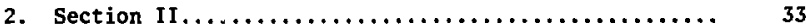

a. Effect of 3 HdT on WI 38 cell growth........... 34

(1) Labeling with low levels of $3_{\mathrm{HdT}} \ldots \ldots \ldots \ldots \ldots . . . . .35$

(2) Labeling with high levels of $3_{\mathrm{HdT}} \ldots \ldots \ldots \ldots . . . . .44$

b. Effect of different methods of slide prel aration on labeling index.............. 63

c. DNA distribution of dividing and nondividing

WI-38 cells......................... 65

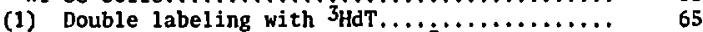

(2) Labeling with high levels of ${ }^{3} \mathrm{HdT} \ldots \ldots \ldots \ldots . . . .72$

B. Premature Chromosome Condensation-Autoradiographic

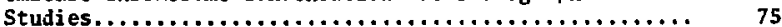

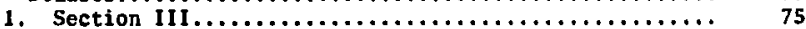

a. Fusion of WI-38 cells with mitotic CHO cells..... 76

b. Fusion of WI-38 cells with mitotic HeLa cells.... 77

Discussion.................................. 37

A. Cytophotometric-Autoradiographic Studies............ 97

1. Section $1 . \ldots \ldots \ldots \ldots \ldots \ldots \ldots \ldots \ldots \ldots \ldots \ldots \ldots \ldots \ldots \ldots$

a. DNA distribution of dividing and nondividing WI-38 cells....................... 97

b. Nondividing WI-38 cells:out-of-cycle vs. slowly cycling. 
2. Section II.............................. 107

a. Effect of 3HdT on WT-38 cell growth.......... 108

(1) Labeling with low levels of 3 HdT.......... 108

(2) Labeling with high levels of ${ }^{3} \mathrm{HdT} \ldots \ldots \ldots \ldots, 111$

b. Effect of different methods of slide preparation on LI ...................... 114

c. DNA distribution of dividing and nondividing WI -38 cells............................ 115

(1) Double labeling with 3 HdT .............. 115

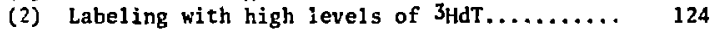

B. Premature Chromosome Condensarion-Autoradiographic

Studies, Section Irr........................... 125

C. Is Finite Cellular Life-Span In Vitro Related to

Aging In Vivo?............................. 128

D. Loss of Rroliferative Capacity for Different Tissue

Type........................................... 135

1, ǩenewing tissue............................... 136

2. Expanding tissue.............................. 138

3. Static tissue.............................. 140

E. Possible Mechanisms of Finite Cellular Life-Span $\underline{\text { In }}$ Vitro........................................ 141

F. A Profile of the Nondividing Cell in Aging W1-38

Cultures......................................

CONCLUSIONS $. \ldots \ldots \ldots \ldots \ldots \ldots \ldots \ldots \ldots \ldots \ldots \ldots \ldots \ldots \ldots \ldots \ldots, 147$

APPENDIX $. \ldots \ldots \ldots \ldots \ldots \ldots \ldots \ldots \ldots \ldots \ldots \ldots \ldots \ldots \ldots \ldots \ldots \ldots, \quad 150$ 
LIST OF FIGURES AND TABLES

Page

Figures

1. Feulgen DNA stain content of aging WI-38 cultures.......... 29

2. Effect of continuous exposure to low levels of

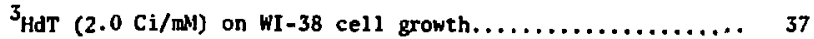

3. Labeling index of WI-38 cells continuously

exposed to low levels of $3^{\mathrm{HdT}}(2,0 \mathrm{ci} / \mathrm{mM}) \ldots \ldots \ldots \ldots \ldots \ldots$

4. Coulter volume distribution of WI-38 cells continuously

exposed to low levels of ${ }^{3} \mathrm{hdT}(2.0 \mathrm{ci} / \mathrm{mm}) \ldots \ldots \ldots \ldots \ldots \ldots . \ldots 42$

5. Effect of continuous exposure to low levels of

$3_{\text {HdT }}(2.0 \mathrm{Ci} / \mathrm{mH})$ on young $\mathrm{WI}-38$ cul ture growth......... 46

6. Effect of continuous exposure to low levels of

${ }^{3} \mathrm{HdT}(2.0 \mathrm{Cl} / \mathrm{FN})$ on middle-aged VI-38 culture growth...... 48

7. Effect of tontinuous exposure to low levels of

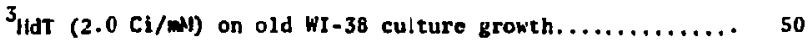

B. Effect of continuous exposure to high levels of

$3_{\text {ILT }}(20.0 \mathrm{Cj} / \mathrm{m})$ on $\mathrm{WL}-38 \mathrm{cell}$ growth.............. 53

9. Labeling index of w1-38 cells continuously exposed

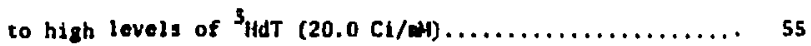

10. Effect of continuous exposure to high lovels of

$3_{\text {IldT }}(20.0 \mathrm{cJ} / \mathrm{m})$ on $\mathrm{wI}-38$ cell trowth.............. 58

11. Labeling index of Mt-38 cells continuously

expostd to high levels of ${ }^{3}$ IldT $(20,0 \mathrm{Cl} / \mathrm{mH}) \ldots \ldots \ldots \ldots 5$ 
12. Coulter volume distribution of WI-38 cel]s

continuously exposed to high levels of

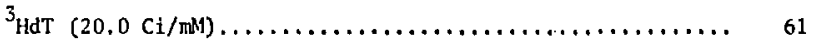

13. Feulgen DNA stain content of aging WI-38 cultures

double labeled with ${ }^{3}$ HdT $\ldots \ldots \ldots \ldots \ldots \ldots \ldots \ldots \ldots \ldots \ldots \ldots$

14. Feulgen DNA stain content of aging WI-38 cultures

exposed to high tevels of ${ }^{3} \mathrm{HdT}(20.0 \mathrm{Ci} / \mathrm{mH}) \ldots \ldots \ldots \ldots \ldots . \ldots 74$

15. Coulter volume distribution or mitotic CHO cells

collected in Colcenid by the shake-synchrony method...... 80

16. Coulter volume distribution of labeled mitotic

HeLa colls collected in Colcemid................... 82

17. Autoradiograph of an unlabeled $H^{\prime} I-38 G_{1}$ diploid PCC

and labeled mitotic Hela chromosones............... 85

18. WI-38 $\mathrm{G}_{2}$ diploid PCC and mitotic Hel.a cloromosomes......... 87

19. Wi-36 $C_{1}$ tetraplold PCC with approximately 92 single

chromatds and mitotic Hela chromosomes.............

20. Autoradiograph of an unlabeled k'-38 PCC

containing approximately 92 paired chromatids

and lahcled mitotic HeLa chromosomes............... 91

21. The changing relationships of the frequency of

proliferating and quiescent cells with culture age....... 104

22. Photonicrograph of an aging WI-j8 cell with micronuclei.... 121 
xvi

Page

Tables

1. Modal channe1 of Coulter volumes of WI-38 cells grown with and without $2.0 \mathrm{Ci} / \mathrm{mM}{ }^{3} \mathrm{HdT} \ldots \ldots \ldots \ldots \ldots \ldots \ldots . \ldots \ldots$

2. Modal channel of Coulter volumes of WI-38 ce11s grown with and without $20.0 \mathrm{ci} / \mathrm{mM} 3_{11 \mathrm{dT}} \ldots \ldots \ldots \ldots \ldots \ldots \ldots \ldots \ldots$

3. Modal channel of Coulter volumes of KI-38 cells grown with and without $20,0 \mathrm{Ci} / \mathrm{mM} 3_{\mathrm{HdT}} \ldots \ldots \ldots \ldots \ldots \ldots \ldots \ldots$

4. Effect of different methods of slide preparation on labeling index........................... 64

5. Coefficient of variation of DNA values and ratio of $4 C$ to $2 C$ DNA values with age................ 71

6. Mitotic index of CHO cells collected in Colcemid.......... 78

7. Percentage of nondividing cells in parent cultures, frequency of PCC, and cell cycle distribution of unlabeled cells with PCC.................... 92

8. Number of observed and expected WI-38 cells with PCC in culture $A, \ldots \ldots \ldots \ldots \ldots \ldots \ldots \ldots \ldots \ldots \ldots \ldots \ldots \ldots$ 


\section{BIBLIOGRAPHY}

Absher, P.M., Absher, R.G. and Barnes, W.D,: Genealogies of clones of diploid fibroblasts: Cinemicrographic observations of cell division patterns in relation to population age. Exptl. Cell Res., 88: 95-104, 1974 .

Adelman, R.C., Stein, G., Roth, G.S, and Erglander, D.: Age-dependent regulation of mamulian DNA synthesis and cell proliferation in vivo. Mech. Age. Dev, 1: 49-59, 1972.

Ahearn, M.J., Lewis, C.W., Campbell, L.A, and Luce, J.K.: Nuclear bleb formation in human bone marrow cells during cytosine arabinoside therapy. Nature, 215: 196-197, 1967.

Ahearn, M.J., Trujillo, J.M., Cork, A., Fowler, A. and Hart, J.S.: The association of nuclear blebs with aneuploidy in human acute leukemia. Cancer Res., 34: 2887-2896, 1974. Altman, K.I., Gerber, G.B. and Okada, S.: Radiation effects on cell progress through the life cycle. In: Radiation Biochemistry. Acaderic Press, New York, 1970, pp, 189-246. Mvarez, Y, and Valladares, Y.: Nifferential staining of the cell cjele. Nature Nen Biol., 238: 279-280, 1972. Baserga, R.: The rolationship of the cell cycle to tumor growth and control of coll division: A review. Cancer Res, 25: $581-595,1965$. 
xviii

Baserga, R.: Autoradiographic methods. In: Methods in Cancer

Research. Volune 1. Edited by H. Busch. Academic Press, New York, 1967, pp. 45-116.

Baserga, R.: Biochemistry of the cell cycle: A review. Cell

Tissue Kinet., 1: 167-191, 1968.

Baserga, R., Rovera, R, and Farber, J.: Control of cellular

proliferation in human diploid fibroblasts, In Vitro, 7: 80-87, 1971 .

Bremer, J.L.: The fate of the remaining ling tissue after

lobectony or pnemonectomy, J. Thorac. Cardiovasc. Surg., 6: $336-343,1937$.

Brody, H.: Organization of the cerebral cortex, III. A study

of aging in the human cerebral cortex. J. Conp. Neurol., 102: 511-556, 1955.

Bucher, N.L.R., Swaffield, M.N. and DiTroia, J.F.: The influence of age upon the incorporation of thymidine- $2-\mathrm{C}^{14}$ into the DNA of regenerating rat liver. Cancer Res,, 24: 509-512, 1964.

Buetow, D.E.: Cellular content and cellular proliferation changes in the tissues and organs of the aging mammal. In: Cellular and Molecular Renewal in the Mammalian Body. Edited b)' I.L. Cameron and J.D. Thrasher. Academic Press, New Yoik, 1971, pp, 87-106.

Cameron, I.L.: Cell proliferation and renewal in aging mice. J. Geront., 27: 162-172, 1972 ,

Caspersson, T.O, and Lomakka, G.M.: Scanning microscopy techniques for high resolution quantitative cytochemistry. Ann. 
N.Y. Acad. Sci., 97: 329-526, 1962.

Cleaver, J.E.: Interphase replication of DNA and the cell cycle.

In: Thymidine Metabolism and Cell Kinetics. Frontiers of

Biology. Volume 6. Edited by A. Neuberger and E.L. Tatum, John Wiley and Sons, New York, 1967, pp, 104-136.

Cleaver, J.E., Thomas, G.H. and Burki, H.J.: Biological damage

from intranuclear tritium: DNA strand breaks and their repair. Science, 177: 996-998, 1972.

Cristofalo, V.J.: Animal cell cultures as a model system for the study of aging. Adv, Geront. Res., 4: 45-79, 1972.

Cristofalo, V.J.: The thymidine labeling index as a criterion of aging in vitro. Gerontologia, 1975, in press.

Cristofalo, V.J. and Kritchevsky, D.: Cell size and nucleic acid content in the diploid human cell line WI-38 during a ing. Med. Exp., 19: 313-320, 1969.

Cristofalo, V.J. and Sharf, B.E.: Cellular senescence and DNA synthesis: Thymidine incorporation as a measure of population age in huran diploid cells. Exptl. Cell Res., 76: 419-427, 1973 .

Crowley, C. and Curtis, H.J.: The development of somatic mutations with age. Proc. Nat. Acad. Sci,, 49: 626-628, 1963. Cudkowicz, G., Upton, A.C., Shearer, G.M. and Hughes, W. L.: Lymphocyte content and proliferative capacity of serially 
transplanted mouse bone marrow ce11s, Nature, 201: 165-167, 1964.

Curtis, H.J.: Blological mechantsms underlying the aging process. Science, 141: 686-694, 1963.

Daniel, C.H.: Aging of cells during serial propagation in vivo. Advan, Gerontol. Res., 4: 167-199, 1972.

Daniel, C.W., Aidells, B.D., Medina, D. and Faulkin, J., Jr.: Unlimited division potential of precance - ds mouse mannary cells after spontaneous or carcinogen-induced transformation, Fed. Proc., 34: 64-67, 1975.

Daniel, C.W., DeOme, K.B., Young, J.T., Blair, P.B. and Faulkin, L.J., Jr.: The in vivo life span of normal and preneoplastic mouse mammary glands: a serial transplantation study. Pathology, 64: 53-60, 1968.

Laniel, C.W. and Young, L.J.T.: Influence of cell division on an aging process, Life span of mouse mamary epithelium during serial propagation in vivo. Exptl. Cell Res., 65: 27-32, 1971.

Davis, M.L., Upton, A.C. and Satterfield, L.C.: Growth and senescence of the bone marrow stem cell pool in RFM/Un mice. Froc. Soc. Exp. Biol. Med, 137: 1452-1458, 1971.

Deamer, D.W, and Conzales, J.: Autofluorescent structures in cultured W1-38 cells, Arch, Biochen, Biophys. 165: 421-426, 1974. 
$x x i$

Decosse, J.J. and Aiello, N.: Feulgen hydrolysis: Fffect of acid and temperature. J. Histochem. Cytochem., 14: 601-604, 1966.

Deitch, A.: Cytophotometry of nucleic acids. In: Introduction to Quantitative Cytochemistry. Edited by G.L. Wied, Academic Press, New York, 1966, PP. 327-354.

Deitch, A.D., Wagner, D. and Richart, R.M.: Conditions influencing the intensity of the Feulgen reaction. J. Histochem. Cytochem., 16: $\quad 571-379,1968$.

Dell 'Orco, R.T.: Maintenance of human diploid fibrobla'sts as arrested populations. Fed. Proc., 33: 1969-1972, 1974.

Dell 'Orco, R.T., Mertens, J.G. and Kruse, P.F., Jr.: Doubling potential, calendar time, and donor age of human diploid cells in culture. Expt1. Cel1 Res., 84: 363-366, 1974.

Dendy, P.P. and Cleaver, J.E.: An investigation of (a) variation in rate of DNA-synthesis during $S$-phase in mouse $L$ cells (b) effect of ultra-violet radiation on rate of DNA-synthesis. Int, J, Radiat. Biol., 8: 301-315, 1964. Drahota, z. and Gutmann, E.: The influence of age on the course of reinnervation of muscle. Gerontologia, 5: 88-109, 1961.

Lagle, H.: The minimum vitamin requi rements of the $L$ and Hela cells in tissue culture, the production of specific vitamin deficiencies, and their cure, J. Exp. Med., 102: 595-600, 1955. 
xxii

Eagle, H.: Amino acid metabolism in mammalian cell cultures. Science, $130: 432-437,195:$

Epifanova, O.I, and Terskikh, V.V.: on the resting periods in the cell life cycle. Cell Tissue Kinet., 2: 75-93, 1969. Garcia, A.M.: Cytophotometric studies on haploid and diploid cells with different degrees of chromatin coiling. Aun. N.Y. Acad. Sci., 157: 237-249, 1969.

Garcia, A.M.: Stoichiometry of tye binding versus degree of chromatin coiling. In: Introduction to Quantitative Cytochemistry. Edited by G.L. Wied and G.F. Bahr. Academic Press, New York, 1970, pp. 153-170.

Gelfant, S.: A new theory on the mechanism of cell division. In: Cell Growth and Ce11 Division, Symp. Intern. Soc. Cell Bio1. Volume 2. Edited by R.J.C. Harris, Academic Press, New York, 1963, pp. 229-259.

Gelfant, S, and Smith, J.G., Jr.: Aging: Noncycling cells an exp:anation, Science, 178: 357-361, 1972.

Girardi, A.J., Jensen, F.C. and Koprowski, H.: $\mathrm{SV}_{40^{-i} \text { induced }}$ transformation of human diploid cell: Crisis and recovery. J. Ce11, Comp. Physiol, 65: 69-84, 1965.

Goldstein, S.: Lifespan of cultured cells in progeria. Lancet, l: 424,1969 .

Goldstein, S., Littlefield, J.W. and Soeldner, J.S.: Diabetes mellitus nnd aging: Diminished plating efficiency of cultured 
human fibroblasts. Proc. Nat, Acad. Sci,, 64:

$155-160,1969$.

Good, P.: Ageing cej] cultures. Nature, 252: 180, 1974.

Hamerton, J.L., Taylor, A.I., Angell, R. and McGuire, V.M.:

Chromosome investigations of a small isolated human population:

Chromosome abnormalities and distribution of chromosome counts

according to age and sex among the population of Tristan de

Cunha. Nature, 206: 1232-1254, 1965.

Harris, H., Watkins, J.F., Ford, C.E, and Schoef1, G. I.:

Artificial heterokaryons of aninal cells from different species.

J. Cell Sci., 1: 1-30, 1966.

Hayflick, L.: The limited in vitro lifetime of human

diploid cell strains. Exptl. Cell Res., 37: 614-635, 1965.

Hayflick, L.: Current tlieories of biological aging.

Fed. Proc, 34: 9-13, 1975.

Hayflick, L. and Moorhead, P.S.: The serial cultivation

of human diploid cell strains. Exptl. Cell Res,, 25: 585-621, 1961.

lolland, J.J., Kohne, D. and Doyle, M.V.: Analysis of virus replication in ageing human fibroblast cultures. Nature, 245:

316-319, 1973.

Holliday, R, and Tarrant, G.M.: Altered enzymes in ageing

human fibroblasts, Nature, 238: 26-30, 1972.

Howard, A, and Pelc, S.R.: Nuclear incorporation of $\mathrm{p}^{32}$ as 
$x \times i v$

demonstraced by autoradiographs. J, lixp. Cell Res., 2: 178-187, 1951.

lloward, A. and Pelc, S.R.: Synthes is of desoxyribonucleic acid in normel and irradiated cells and les relacion to chromosone breakage. Hercdjty, Suppl, 6: 261-273, 1952.

lluang, C.C. and Moore, G.I., Chronosomes of 14 hematopoictic cell lines derived fron peripheral blood of persons with and without chromosome anomalies. J. Nat. Cancer Inst., 43: $1119-1128,1969$.

Jacobs, P.A., Brunton, M., Court Brown, H.Ak, Doll, R, and Goldstein, Il,: Change of human chromosonc count distribusions with age: Evidence for a sex difference, Nature, 197: $1080-1081,1963$.

Johnson, R.T. and Rao, P.N.: Namalian cell fusion: induction of premature chronosome condensation in interphase nuclei. Nature, 226: 717-722, 1970a.

Johnson, R.T., Rao, P.N. and Hughes, H.O.: Mammalian cell fusion. III. A Hela cell inducer of premature chromosome condensation aceive in cells fron a variety of animal species. J. Cell. Phystol., 76: 151-158, 19706.

Kohn, R,R.: Aging and cell division. Sctence, 188: 203-204, 1975

Krooth, R.S., Shaw, M.H. and Campbell, B.K.: A persistene strain of diploid flbrobjasts. J, Nat. Canc. Inst., 32: 1031-1044, 1964. 
Lajtha, l.t.: Dn the concept of the cell cycte. J. Cell. Luaps. Phytial., suppl., 6:: 143, 5963.

t.esher, S. and sacher, G.A.: Ifrects of ape on cell proliferation in nouse duodenal ergpes. tixp. Geronk., 3: 211-32, 1906.

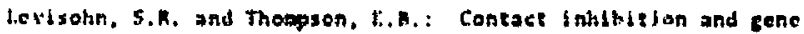
cxprosxion in ITH/t celi bybid Ithes. 9. Cell. Mrsiol., st: $2: 5-232,1975$.

LeVy. J.A., Virolatnen, H. and Defendi, V.: Ituan Iymohoblastold Ifncs from dyeph node and apleeh. Cancer, $2:$ 517-524, 1968. Lewis, C.M. ant Tarrant, G.\$.: Jrror theory and ageine in huash diplotd flbroblasts. Nature, 259: $516-315,1072$.

Lima, 1.. Halaise, th. and Macicira-Coetho, A.: Aging in viere: Iffect of low dose rase Irradiation on the ditision potential of chick cubryonic fibroblases. Lxpe1. Cell Res., 73: 545-350, 1972.

lifet:, J, and Criseofalo, Y.J.: Vleraseructurul changes accompanying the aging of human diploid cells in culture. J. Ulerastruet. Res., 39: 43-56, 1972.

Longaere, J.J. and Johanseann, R.: An experimeneul seudy of the face of the rewaining lung following cotal pneunonectomy. J. Thorac. Surg., 10: 131.249, 1940. Macleiru-Coelho, $A .:$ Are non-dividing colls present in aging cell cultures? Nature, 248: $121-422,1974$, 
xxyi

Maclelra-Coelho, A.: Ageing cell cultures, Nature, 252:

180, 1974.

Macielra-Coelho, $\wedge$. and Berumen, L,: The cell cycle during growth inhibition of human embryonic fibroblasts in vitro. Proc. Sac. Exp. Biol, Med., 144: 43-47, 1973.

Macieira-Coelho, A., Ponten, J, and Philipson, L.: The division cycle and RNA symthesis in diploid hunan cells at different passage levels in viero. Exptl. Cell Res., 42: 673-684, 1966.

Marshak, A. and Byron, R.L., Jr.: The use of regenerating liver as a method of assay. Proc. Soc. Exp. Biol., 59: 200-202, 1945. Merein, G.M., Sprague, C.A. and Epstein, C.J.: Replicative life-span of cultivated human cell. Effect of donor's age, tissue, and genotype, Lab. Invest., 23: 86-91, 1970.

Matsul, S., Weinfeld, H. and Sandberg, A.A.: Fate of chromatin of interphase nuclei subjected to "prophasing" in virus-fused cells. J. Nat, Cancer Inst., 49: 1621-1630, 1972 .

Mauer, A.M., Saunders, E.F, and Lampkin, B.C.: Importance of the non-dividing leukemic cell. In: Recent Results in Cancer Research. Normal and Malignant Cell Growth. Edited by R.J.M. Fry, M.L. Griem and W.H. Kirsten. Springar Verlag, New York, 1968, Pp. 168-174,

Maya11, B.H.: Deoxyribonucleic acid cytophotometry of stained human leukocytos. I. Differences among cell types. J. Histochem. Cytochen., 17: 249-257, 1969. 
xxvji

Mayal1, B.ll. and Mendelsohn, M.L.: Veoxyribonucleic acid cytophotometry of stained human leukocytes. II. The mechanical scanner of CYDAC, the theory of scanning photometry and the magnitude of residual errors. J. Histochem. Cytochem., 18: $383-407,1970$.

McCreight, C.E. and Sulkin, K.M.: Cellular proliferation in the kidneys of young and senile rats following unilateral nephrectomy, J. Gerontol., 14: 440-443, 1959. Mendelsohn, M.L.: Autoradiographic analysis of cell proliferation in spontaneous breast cancer of C3H mouse. III. The growth fraction, J. Nat. Cancer Inst., 28: 1015-1029, 1962.

Merz, G.S. and Ross, J.D.: Viability of human diploid cells as a function of in vitro age, J. Cell, Physiol., 74: 219-222, 1969. Messier, B. and Leblond, C.P.: Cell proliferation and migration as revealed by radioautography after injection of thymidine- $\mathrm{H}^{3}$ into male rats and mice. Amer. J. Anat,, 106: 247-265, 1960. Moore, G.E, and Mclimans, H.F.: The life span of the cultured normal ce11: concepts derived from studies of human lymphoblasts. J. Theor. Biol., 20: 217-226, 1968.

Mueller, G.C., Kajiwara, K., Stubblefield, E. and Rueckert, R.R.: Moleculnr events in the reproduction of animal cells. I. The effect of puromycin on the duplication of DNA. Cancer Res., 22: $1084-1090,1962$. 
xxvili

Nilausen, $k$. and tireen, H.: Reversible arrest of growth in $f_{1}$ of an established fibroblast line (3T3). Bxpt1. Coll Res., 40; $166-168,1965$.

Orgel, L.F.: The maintenance of the accuracy of protein synthesis and its rolovance to agoing. Biochemistry, 49: 517-521, 1963.

Orgel, L.F.: Ageing of clones of mamalian cells. Nature, 243: $441-445,1973$.

Owen, M. and MacPherson, S.: Cell population kinetics of an osteogenic tissue. II. J. Cell Biol., 19: 33-44, 1963.

Pederson, T, and ielfant, S.: $G_{2}$-population cells in mouse kidney and duodenum and their behavior during the cell division cycle. Expt1. Cell Res.. 59: 32-36, 1970.

Putes, T.D., Farber, R.A., Tarrant, G.M. and Holliday, R.: Altered rate of DNA replication in ageing human fibroblast cultures. Nature, 251: 434-436, 1974.

Petursson, G., Coughlin, J.I, and Meylen, C.: Long-term cultivation of diploid rat cells. Expt 1. Cell Res., 33: 60-67, 1964.

Prescott, D.M.: The cell cycle and the control of cellular reproduction. In: Genetic Organization: A Comprehensive Treatise. Volume 2, Edited by A.K. Ravin and E.W. Caspari. Acadenic Press, New York, 1975, in press.

Price, C. B, and Makinodan, T.: Immunologic deficiencies in senescence, I. Characturization of intrinsic deficiencies. J. Innunol, 108: 403-412, 1972 , 
$x \times 1 x$

Quast ler, II.: The nnalysis of cell population kineties. In: Cell Proliferation. A Guiness Symposium, tidited by L.F. Lamerton and R.of.r. Fry. F.x. Duvis, Thitadelphia, Ig65, pp. I8-54.

Rao, P.R. and Johnson, R.T.: Cell fusion and its application to studies on the regulation of the coll cycle. In: Methods in Cell Physiology, lolume 5. Fdited by D.Mt. Prescott, Acaderic Press, New York, 1972, Pp. 35-126.

Robbins, E., lentzch, $C$, and Micald, A.: The centriolc cycle in synthronized HeLa cells. J. Cell Blol., 36: 329-339, $196 E$. Robbins, E., Levine, E.M. and Eagle, H.: Morphologic changes accompanying senescence of cultured human diploid cells. J. Lxp. Med., 131: 1211-1222, 1970.

Ryan, J.M., Duda, G, and Cristofalo, V.J.: Error accumulation and aging in human diploid cells. J. Geront., 29: 616-621, 1974.

Saksela, E. and Moorhead, P.S.: Aneuploidy in the degenerative phase of serial cultivation of human cell strains. Proc. Nat. Acad. Sci., 50: 390-395, 1963.

Saunders, J.W., Jr.: Death in embryonic systens. Science, 154: $604-612,1966$.

Siminovitch, L., T111, J.E. and McCulloch, E.A.: Decline in colony-forming ability of marrow cells subjected to serial transplantation into irradiated mice. 3. Cell. Comp. Physiol., 104: $23-32,1964$, 
Snedecor, 6.K. and Cochran, H.C.: Two-way classiflections. In:

Statstfeal Methods. Iowa State University Press, Iown, 1967. pp. 327-329.

Stanners, C.R., Eliceiri, G.L. and Green, H.: Two types of ribosomes in mouse hamster hybrid cel1s. Nature hew Blol., 230: 52-54, 1971 .

Stubblefield, E, and Klevecz, R,: Synchronization of Chinese hanster cells by reversal of Colconid inhibition, Exptl. Cell Res., 40: $660-664,1965$.

Swift, H.H.: The desoxyribose nueleic acid content of animal nuclei. Physiol. 2001, 23: 169-198, 1950,

Takahaski, N., Hogg, J,D., Jr, and Mendelsohn, M.L.: The automatic analysis of FuM curves. Cel1 Tissue Kinet., 4: 505-518, 1971.

Terasima, T, and Tolmach, L.J.: Growth and nuclerc acid synthesis in synchronously dividing populations of Hela cells. Exptl. Cel1 Res., 30: 344-362, 1963.

Thompson, K.V.A. and Holliday, R.: Effect of temperature on the longevity of human fibroblasts in culture. Exptl, Cell Res., 80: $354-360,1973$.

Thrasher, J.D.: Age and the cell cycle of the mouse esophageal epithelium, Exp. Geront,, 6: 19-24, 1971.

Tonkins, G.A., Stanbridge, E.J. and Hayflick, L.: Viral probes of aging in the human diploid cell strain WI-38. Proc. Soc. Exp. Biol, Med., 146: 385-390, 1974. 
$x \times x i$

Venderly, C.: Cytophotometry and histochemistry of the cell cycle. in: The Cell Cycle and Cancer. Edited by R. Baserga, Marcel Dekker, Neh York, 1971, pp. 227-268.

Walker, P.N.B. and Yates, H.B.: Nuclear components of dividing cells. Proc. Roy. Soc. (Biol.), 140: 274-299, 1952.

Williamson, A.R. and Askonas, B.A.: Senescence of an antibody-forming cel1 clone. Nature, 238: 337-339, 1972. 
PREFACE

The contents of this dissertation represent work done by the authoress at the Wistar Institute of Anatory and Biology (Philadelphia, Pennsylvania), and the Lawrence Livermore Laboratory (Livermore, California). Portions of this warh were published as follows:

(1) Graul, R.M, ${ }^{a}$ Mendelsohn, M. L., Mayall, B.H. and Cristofalo, V.J.: Cellular DNA: A cytophotometric and autoradiographic analysis of aging in WJ-38 cells. Gerontologist, 12: 35, 1972 (abstract).

(2) Yanishevsky, R, and Carrano, A.V.: Prematurely condensed chromosomes of aging human cell cultures. J. Cell Biol., 63: 383a, 1974 (abstract).

(3) Yanishevsky, R. and Carrano, A.V.: Prematurely condensed chromosomes of dividing and nondividing cells in aging human cell cultures. Expt1. Cell Res., 90: 169-174, 1975.

(4) Yanishevsky, R., Mendelsohn, M.L., Maya!1, B.H. and Cristofalo, V.J.: Cytophotometric and autoradiographic studies of dividing and nondividing human diploid cells in culture. In Vitro, 8: 428, 1973 (ubstract).

(5) Yanishevsky, R., Mendelsohn, M.L., Mayal1, B.H. and Cristofalo, V.J.: Proliferative capacity and DNA content of aging luman diploid celis in culture: A cytophotometric and

$a_{R}$. Yanishevsky formerly was R,M. Graul. 


\section{$x x x i j$}

autoradiographic analysis. J. Ce11. Physio1., 84: 165-170, 1974. 


\section{INTRODUCTION}

The conversion of cells from the dividing to the nondividing state is a common occurrence in nature. For example, cells may cease dividing in response to environnental stress, as they mature and differentiate, or as they senesce. Human diploid cultures, strain HI-38, present an intriguing model for the study of the loss of proliferative capacity. Soon after being established in culture (phase I), these populations proliferate vigorously and can be serially subcultivated (phase II): but with successive subcultivations, the growth rate progressively declines (phase III) and ultimate'y the culture cannot be propagated (Hayflick and Moorhead, 1961; Hayflick, 1965). It has been suggested that the number of loublings the culture attains is intrinsically controlled and that the limited doubling potential is a cellular expression of aging. The work presented here involves the identification of the phase of the 1 ife cycle wherein WI- 38 cells lose their ability to divide.

The framework for present-day concepts of the life cycle of eukaryotic cells is based on the classical work of lloward and Pelc (1951, 1952). They discovered that deoxyribonucleic acid, or DNA, was synthesized in interphase (as distinct from mitosis) and only during a limited, discrete part of the interphase. Thus, they extended the cell cycle from a two-phase system (mitosis and interphase) to a 
four-phase system: mitosis $(M)$, pre-synthetic phase $\left(G_{1}\right)$, DNA synthesis phase (S), and post-synthetic phase $\left(G_{2}\right)$.

Out-of-cycle (nondividing) cells predominate in many normal tissues of the adult organism (e.g., Epifanova and Terskikh, 1969) and in many malignant $t$ issues, such as leukemic cells (Maurer et al., 1968). Mendelsohn (1962) has operationally defined the growth fraction as the proportion of cells which proliferate in a population. Some representative growth fractions are: bone marrow sten cells, 0.8 ; 1iver parenchyma, 0.001 ; adult neurons, 0 ; and mammary tumors of C3H mice, 0.40. In the case of tumors, it is clearly of paramount importance to know whether the arrest of the nondividing cells is reversible.

Nondividing cells may bo classified into two populations on the basis of the reversibility of the nondividing state. Lajtha (1963) and Quastler (1963) have termed reversibly arrested cells (cells which reenter the proliferating fraction by an appropriate stimulus) as $G_{0}$ cells (e.g., liver). Nonreversible cells lose their capacity to divide as they mature. Some, such as nerve cells, remain in the nomproliferative state for the 1 ffespan of the organism. At the other extrene, others, such as neutrophilic granulocytes, survive for only a matter of days.

An aging WI-38 culture is considered to be a "mixed population" with respect to cell cycle kinetics and biochenistry, The simplest kinetic model would consist of two compartments, proliferating and nonproliferating. Wh th age, the proliferating compartment shows 
marked heterogeneity of cell cycle times (Absher et al., 1974; Maciera-Coelho et a1., 1966). A number of biochemical parameters also show diversity. Lysosomes (Robbins et al., 1970; Lipetz and Cristofalo, 1972), and lipofuchsin, or "age-pigment" granules (Deamer and Gonzales, 1974), increase progressively with culture age, but they may be absent, or exist in widely varied amounts in single cells of aging cultures. Most research of ajing WI-38 cultures has been performed on mass populations. The wide diversity of kinetic and biochemical parameters among individual cells must be considered in the interpretation of data from mass populations, where individual variations are lost.

The decrease in growth rate in aging WI-38 cultures appears to be due to both lengthening of the average cell cycle times (Macieira-Coelho et a1., 1966; Absher et a1., 1974) and to a progressive increase in the nonproliferating fraction of the population. The increase in the nonproliferating fraction is shown by the decreasing ability of single cell isolates to divide and form clones (Merz and Ross, 1969), and by an increase in the percent of cells unable to incorporate the radioactively labeled (tritium) deoxyribonucleoside thymidine ( ${ }^{3} \mathrm{HdT}$ ) (Cristofalo and Sharf, 1973). Both of these responses increase exponentially with the age of the culture. Cristofalo and Sharf (1973) showed, by statistical analysis of their data, that the percent of nondividing cells was a more accurate criterion of culture age (percelt of life-span completed) than passage number. 
For the experiments reported here age was defined by the perrent of nondividing cells. Nondividing cells were cells which did not incorporate ${ }^{3}$ HdT for 48 hours (approximately two generations) prior to fixation. DNA synthesis and cell division are almost always correlated and incorporation of a DNA precursor during continuous exposure is a well accepted, convenient indication of whether a cell is actively involved in the nitotic cycle (e.g., Cleaver, 1967). It is believed that the majority of WI- 38 cells designated nondividing are destined to dit without dividing again. Further consideraticn is given to these concepts in the Discussion.

Pinpointing the phase in the cell cycle where cells arrest is just a step in understanding the sensitive events which led to that arrest. Knowledge of events specific to the phases of the cell cycle is scant. In the most simplistic view, $G_{1}$ is the period during which cells prepare for the initiation of DNA synthesis and $G_{2}$ is the period during which cells prepare for the initiation of mitosis. Cells may cease progression through the cell cycle in either the $G_{1}$ phase (e.g., Mueller, et al., 1962; Lajtha, 1963; Nilhausen and Green, 1965) or in the $G_{2}$ phase (e.g. . Gelfant, 1963; Owen and MacPherson, 1963; Pederson and Gelfant, 1970) of the mammalian cell cycle, although $G_{1}$ arrest is, by far, more common (see review by Prescott, 1975, for an extensive discussion; also reviews by Baserga, 1965, 1968, and Epifanova and Terskikh, 1969). The cell kinetic data of Macieira-Coelho et al. (1966) showed that in aging WI-38 cultures the increase in average 
cell cycle time was due primarlly to a lengthening of the $G_{1}$ phase. In addition, there were cells with very long $G_{2}$ periods. This suggested that WI-38 cells may cease cycling in $G_{1}$ and $G_{2}$. Gelfant and Smith (1972) proposed that aging in vivo and in vitro can be explained by the progressive accumulation of nondividing cells in $G_{1}$ and $\mathrm{G}_{2}$. The work presented here is evidence that the loss of proliferative capacity in human cell cultures occurs primarily in the G phase.

To identify the phase(s) of the cell cycle wherein aging WI-38 cells arrest, biophysical and cytological techniques were utilized, in combination, on the same individual cells. Analysis of more than one parameter for Individual cells, although time consuming, is essential to effectively study a "mixed population", such as aging W'-38 cultures. The approach was first to expose cells to ${ }^{3}$ lidT for approximately two cell generations, then to determine the cycle phase in individual cells by one of two methods described below, and finally, for the same cells to score their prollferative status by autoradiographic evidence of uptake of ${ }^{3} \mathrm{HdT}$.

The methods to jdentify the cycle phase of the nondividing h'l-38 cells were 1) determination of the DNA stain content by Feulgen cytophotometry and 2) derermination of chromosome constitution of interphase cells by the technique of premature chromosome comlensation (PCC). Cycle phase may be determined in fixed, single cells by DNA cytophotometry (5wift, 1950; Walker and Yates, 1952; Dendy and 
Cleaver, 1964). A comprehensive review of this subject has been writen by Vendrely (1971). DNA content doubles during the $S$ phase as two coples of the genetic material are made in anticipation of the partitioning of a full complenent into the two daughter cells. If $C$ is defined as the DNA content of a haploid cell, a diplotd cell in $G_{1}$ has the $2 \mathrm{C}$ amount of DNA, and a cell in $\mathrm{G}_{2}$ has the $4 \mathrm{C}$ amount. A cell in $S$ phase has a DNA content between $2 \mathrm{C}$ and $4 \mathrm{C}$.

A cell in $G_{1}$ may also be distinguished from a cell in $G_{2}$ by the presence of single or double chromatids, respectively. However, chroatids are not visible as entities during interphase; the chromosomes uncoll their DNA so that chronatin in interphase cells is, In the context of this discusston, amorphous. Only during the periods of mitosis or meiosts of mamalian cells does chromatin contract into structures recognizable as chromosomes and, traditionally, visualization and analysis of chronosones has been confined to these periods. Johnson and Rao (1970a, 1970b) discovered an ingenious way to visualize the elusive interphase chrosatin. To investigate the regulation of DNA synthests and mitosis they fused various combinations of heterophesic cells. They noted a very interesting phenomenon when aitotic cells were fused with $G_{1}, S$ or $G_{2}$ phase cells; the mitotic cell induced the interphase cell to condense its chromatin Into discrete chromosones. Johnson and Rao termed this phenomenon promature chromosome condensation or PCC. Because of the morphological similarity between PCC Induction and prophase, this phenomenon has also been termed "prophasing" (Matsui, Weinfeld and 
Sandlerg. 1972), In comparison to metaphase chromosomes the PCC chromosomes are quite extended in length. Their morphology reflects the position of the interphase cell in the cycle at the time of fusion; cells in $G_{1}$ phase have single chromatids, cells in $G_{2}$ phase have paired chromatids, and cells in $S$ phase have unevenly condensed chromatin. The experiments reported here utilized PCC to identify, in addition to the cycle phase, the "ploidy level" of nondividing cells. A cell was classified as either "diploid" or "tetraploid" by determination of the chromosome number.

At present, other techniques, such as determination of centriole position and number by transmission electron microscopy (Robbins et al., 1968), and metachromatic staining with safranine and indigo picarmine (Alvarez and Valladares, 1972) 1ack the precision and reliability needed to identify the cell cycle phase.

The research reported in this dissertation is organized into three sections. The cytophotometric-autoradiographic experiments presented in Section I gave initial results which indicated the cycle phase wherein nondividing WI-38 cel1s blocked, and raised further questions which were investigated ir the other sections. Aneuploid DNA content, as a possihle cause of cell arrest, and the effect of continuous exposure to ${ }^{3}$ HdT on cell growth were investigated in the cytophotometric-autoradiographic experiments and the growth kinetic experiments presented in Section II. Finally, in Section III, the chromosomes of nondividing WI-38 cells were examined by the technique 


\section{$-8-$}

of PCC, to define both the ploidy level and the cycle phase of the nondividing cells. 
MATERIALS AND METIHODS

The Materials and Methods are organized as follows: A. procedures to maintain stock cultures, B. theory and procedure of staining DNA with Feulgen dye, and quantitation of the DNA stain content by cytophotometry, $C$. experimental protocol of cytophotometric-autoradiographic studies (two approaches to these studies were utilized and, therefore, divided into Sections I and II), and D. experimental protocol for premature chromosome condensation-autoradiographic studies, or Section III.

\section{A. General Maintenance of Cell Cultures}

Cultures were maintained according to established cell culture techniques (e.g., Hayflick and Moorhead, 1961) and are presented in brief. Cells utilizod were: diploid human cells, III-38; heteroploid human cells, HeLe-S $;$; and heteroploid Chinese hamster ovary cells, CHO, W1-36 cells were obtained from Dr, Vincent J. Cristofalo at the Wistar Institute, Philadelphia, Pennsylvania and from Dr. Leonard Hayflick of Stanford University, Palo Alro, California. Hela-S 3 cells and CHO cells were obtained from Dr. L.H. Thompson of the lawrence Livermore Laboratory, Livermore, California.

W1-38 cells utilized in Section I were cultivated in autoclavable Eagle's Minimal Essential Media (MEM) with Earle's salts (Auto-Fow, Flow Laboratories, Rockvil10, Maryland] and supplemented with an additional mixture of $100 \mathrm{X}$ vitamins as formulated for Eagle's Basal 
Media (BME) (18 V/V) (Eagle, 1955, 1959). Before use, the mediun was supplemented with L-glutanine (2hM), $\mathrm{NaHCO}_{3}(20 \mathrm{mM})$, aureomycin (50 $u g / m 1)$ ald fetal calf serum $(10 \% V / V), W I-38$, CHO and HeLa cells utilized in Sections II and III were cultivated in Q-MEM (Stanners et 1.. 1971) lacking nucleosides (Flow Laboratories). Before use, the medium was supplemented with penicillin (100 units/m1), streptomycin $(100 \mu g / m l)$ and fetal calf serun $(10 \% \mathrm{~V} / \mathrm{V})$.

Manolayer cultures were subcultivated when confluent. Cells were released from the glass surface by trypsin $(0.258)$ in $\mathrm{Ca}^{+2}$ - and $\mathrm{Mg}^{+2}$-free phosphate buffered saline solution (PBS). After suspension of the cells In media containing 104 fetal calf serw, cells were innoculated into vessels at the appropriate density, and incubated at $37^{\circ} \mathrm{C}$ in an atmosphere of $5 \% \mathrm{CO}_{2}: 95 \%$ aix. Nonsenescent $\mathrm{WI}-38$ cultures generally became confluent one week after subcultivation at a split ratio of $1: 10$. Senescent $W I-38$ cultures were subcultivated at a split ratio of $1: 2$, and were sustained by weekly feeding until becoming confluent. CHO cells were maintained in monolayer culture and were subcultured at a split ratio of 1:8. HoLa cells were maintained in suspension culture and woro subcultivated at a split ratio of $1: 8$ when they reached a density of $2 \times 10^{4}$ to $4 \times 10^{5}$ cells $/ \mathrm{ml}$. Cells were olectronically counted using a Coulter Counter.

Stock culturos wero maintained frozon at $-85^{\circ} \mathrm{C}$ in a-MEM containing fecal calf serum (204 $V / V)$ and Dinethylsulfoxide (20\% $W / V$ ). Cultures were periodically monitored for the prosence of mycoplasma by or. Leonard Hayflick of Stanford University. 
B. DNA Cytophotometry

This techrique involved staining the DNA stoichiometrically and measuring the DNA stain content with a scanning cytophotometer. The DNA was stained with basic fuchsin in a Feulgen reaction. The integrated absorbance of the Feulgen stained cells was measured with the mechanical scanner of CYDAC (Cytophotometric Data Conversion), a scanning digital integrating cytophotometer Mayall and Mendelsohn, $1 ; 70)$.

\section{Feulgen cytochemistry}

a. General theory

Accurate quantitative cytochemistry requires specific and stoichiometric chromophore binding to the molecule in question so that the stain content is directly proportional to the substrate. The specificity of the Feulgen stain for DNA is no longer in question (see review by Deitch, 1966). The Feulgen stain binds stoichiometrically to DNA, provided that precaution is observed during specimen preparation and staining, and provided that the specimen behaves in a reproducible manner (Swift, 1950), Occasional nonstoichiometric responses have been traced to the size of the nucleus and the degree of compaction of the [NA (Garcia, 1969, 1970). For example, the highly clumped and dense chromatin of small lymphocytes and neutrophils measures about 58 lower than the DNA of monocytes, which have large nuclei and fine chromatin patterns (Mayall, 1969), WI-38 cells have very large nuclei and such compaction effects are not to be 
expected. Furthermore, results obtained from the cytophotometric measurements of Sections I and II suggest a well behaved stuichiometry on the basis of the precise doubling of $2 \mathrm{C}$ to $4 \mathrm{C}$ to $8 \mathrm{C}$ peaks, and the similar modal DNA value of labeled and urlabeled cells.

In the Feulgen reaction DNA is first depurinated by acid hydrolysis. This unmasks the aldehydes of deoxyribofuranose sugars. The aldehydes react with a decolorized or leuco Shiff reagent, which is then converted into its colored form (Deitch, 1966). The mass of the chromophore, and therefore the amount of DNA, may be determined cytophotometrically.

The Feulgen procedure used (Haya11, 1969), was modified from a protocol given by Deitch (1966), and is described in the staining recipe.

\section{b. Staining recipes}

The Feulgen stain was prepared ir the following manner. Twenty-five grams of basic fuchsin (96\% pure, National Aniline Dye, Allied Chemical Corp., New York] was added to $50 \mathrm{ml}$ distilled water and boiled for 30 minutes. The solution was shaken, cooled to $50^{\circ} \mathrm{C}$, and filtered through number I Whatman paper into a jar covered with aluminum foil. Five $\mathrm{ml}$ of $\mathrm{IN} \mathrm{KCl}$ and $1.0 \mathrm{~g}$ of $\mathrm{K}_{2} \mathrm{~S}_{2} \mathrm{O}_{5}$ were added to the filtrate and shaken to dissolve. The amber-colored solution was stored for 72 hours at ${ }^{\circ} \mathrm{C}$. Before use, $0.125 \mathrm{~g}$ activated charcoal was added, the solution was shaken well and filtered through number 1 Whatman paper. Five grams of $\mathrm{K}_{2} \mathrm{~S}_{2} \mathrm{O}_{5}$ was added to the colorless filtrate. The optimus pH for the Peulgen reaction was 2,3 to 2.9 . 
Slides were stained in the following manner. The slides were hydrolyzed in $5 \mathrm{~N} \mathrm{HCl}$ at rocm temperature for 40 minuces. This method is preferable to the conventional Feulgen hydrolysis in $1 \mathrm{~N} \mathrm{HCL}$ at $60^{\circ} \mathrm{C}$ (Deitch, 1966), because it achieves a Feulgen intensity which is higher and is less criticaliy dependent on time and temperature (DeCosse and Aiello, 1966; Deitch et al., 1968). After hydrolysis, the slides were placed in the Feulgen dye for two hours. To wash the slides they were dipped, three times for five minutes each, into freshly ade wash solution $\left(7.5 \mathrm{ml} 10 \mathrm{~g}_{6}\right.$ anhydrous $\mathrm{K}_{2} \mathrm{~S}_{2} \mathrm{O}_{5}, 7.5 \mathrm{ml} \mathrm{lN}$ $\mathrm{HCl}$, and $135.0 \mathrm{ml}$ distilled water); then the sljdes were dipped, successively, into distilled water for five minutes, absolute ethanol for two minutes, and $x y$ lene for 15 minutes.

For measurements the stained cells were mounted in oil of refractive index 1.552. An interference iliter of $566 \mathrm{~mm}$ defined a spectral band close to the spectral absorbance peak of the feulgen stain.

\section{Scanning cytophotometry}

a. General theory

The Beer Lambert law, the basis of absorption photonetry, describes the relationship between optical density and light transmission by the following formula:

$$
O D=-\log T=k c l
$$

where: 


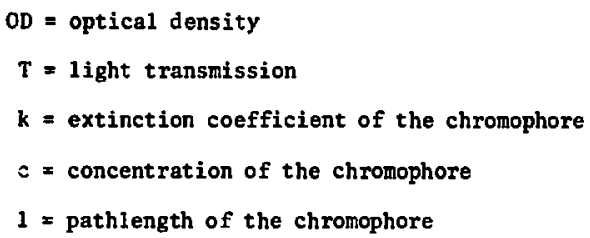

The optical density of a stained specimen is directly proportional to the mass of the chromophore per unit area, since $c=m / v$, where $m$ is the mass of the chromophore and $v$ is the volume of the chromophore. Then,

$$
O D=k(m / v) 1=k m / A
$$

where $A$ is the area of the chromophore.

When applied to biological specimens this relationship frequenty does not hold. This is primarily due to inhomogeneous distribution of the chromophore, or the so-called distributional error. Simple photometric measurement of a field averages the transmissions of all the fractional elements of that fleld. If the elements are heterogeneous, the negative logarithn of the meen of the light transmitted through the whole field, will be less than the mean of the negative logarithms of the light transmitted through all the fractional elements $\left[1 . e .,\left(-\log \Sigma^{A} T\right)<\left(-\varepsilon^{A} \log T\right)\right]$. Scanning cytophotometers are designed to correct for distributional error in the following ways. First, the field to be measured is divided into a large nuber of descrete elements. These elements are small, relative to the resolution of the optics, to reduce heterogeneity within eacil element. Second, the sample olements are taken uniformly from the 
field and integrated. The 1ntegrated optical density is directly proportional to the total amount of chromophore: $\Sigma^{A} O D=\Sigma^{A} \mathrm{~km} / \mathrm{A}=\mathrm{km}$.

Scanning cytophotometry was first used for quantitative cytochemistry by Caspersson (1962).

\section{b. CYDAC instrumentation}

The mechanical scanner of CYDAC consists of: (1) a microscope for specimen viewing; (2) a dual beam photometer with a Nipkow disc scanning in the image plane; (3) a system for transforming and recording the photometric measurements into digital form; and (4) operation controls and displays for visual monitoring. The field containing the cell to be scanned is selected by the operator, who activates the recording process. Light, which is emitted from a ribbon filament tungsten lamp, passes through an interference filter of appropriate wavelength ( $566 \mathrm{~nm}$ for the Feulgen stain) and is split into two beams. One beam passes through the reference optics and is detected by a photomultiplier. The other beam passes through the specimen, and the light transmitted is scanned by a Nipkow disc and detected as discrete sampling elements by a second photomultiplier. The signals from the reference and data photomultipliers are logarithmically converted, the reference signal is subtracted from the 'ata signal to correct for fluctuations in the light source, and finally this difference undergoes analogue to digital conversion. The operator sejects an adjacent clear field and reactivates the recording process, which causes the clear field (background) values to be subtracted from the previous tatal. The final number displayed on the 
accumulator is proportional to the integrated optical density of the object and is represented by the following formulas:

$$
I_{C V}=-\Sigma^{A} \log T
$$

where IOD $\mathrm{CV}$ is the CYDAC value of the integrated optical density. Since:

$$
T=I / I_{0}
$$

where:

$$
\begin{aligned}
& I=\text { intensity of the specimen field } \\
& I_{0}=\text { intensity of the clear field }
\end{aligned}
$$

then:

$$
I O D_{C V}=-G \Sigma^{A} \log \frac{i(r)-i(d)}{i(r)_{0}-i(d)}
$$

where:

$$
\begin{aligned}
& i(r)=\text { reference intensity of the specimen field } \\
& i(d)=\text { data intensity of the specimen field } \\
& i(x)_{0}=\text { reference intensity in the clear field } \\
& i(d)_{0}=\text { data intensity of the clear field } \\
& G \quad=\text { gain }
\end{aligned}
$$

CYDAC values may be converted to absolute integrated optical density $\left(10 D_{A B S}\right)$ :

$$
10 D_{A B S}=\frac{I O D_{C V}}{\rho G}
$$

where $\rho$ is the pixel density in $\mu^{-2}$.

\section{Cytophotometric-Autoradiographic Studies}

DNA cytophotonetry was used to determine the cycle phase, at the time of fixation of the sample, of individual WI-38 cells from 
cultures of various ages. Diploid cells in $G_{1}$ and $G_{2}$ phase had $2 C$ and 4C DNA contents. Cells in $S$ phase had DNA contents intermediate between $2 \mathrm{C}$ and $4 \mathrm{C}$. Autoradiography, used in combination with cytophotometry, allowed the cells to be further classified as nondividing (no incorporation of ${ }^{3} \mathrm{HdT}$ at 48 hours of exposure to the label) or dividing.

A general description of the cytophotometric-autoradiographic procedure is as follows. Tritiated thymidine was added to the culture media for an appropriate time interval. M: :roscope slides of the cells were fixed and the DNA was stained with Feulgen. The DNA content of approximately 100 previously mapped interphase cells for each culture was determined cytophotometrically. The slides were dipped in emulsion for autoradiographic determination of the proliferative status of the same cells. These experiments are presented in Section $I$.

Section II presents a refinement of the techniques used in Section I. Measurements were made on cells whose growth kinetics were unperturbed, Slides were prepared to diminish cellular debris. In addition, the cells were double-labeled with ${ }^{3} \mathrm{HdT}$ to determine the precise boundary of cells in $G_{1}, S$, and $G_{2}$ for analysis of the coefficient of variation of DNA values. Section II also describes the growth kinetics of cells exposed to varjous levels of ${ }^{3} \mathrm{HdT}$.

\section{Section I procodure}

\section{a. Cell cultivation and labeling}


WL-38 ce11s were seeded at $1.3 \times 10^{4}$ cells $/ \mathrm{cm}^{2}$ in Lab-Tek microscope slide chambers (Miles Laboratories, Westmont, I11.) and incubated at $37^{\circ} \mathrm{C}$. Twenty four hours later, ${ }^{3}$ HdT (specific activity, S.A., $2.0 \mathrm{Ci} / m m o l e)$ was added to the mediun to a final concentration of $0.1 \mu \mathrm{Ci} / \mathrm{ml}$ and left in the culture for 48 hours (approximately two cel1 generations].

\section{b. Slide preparation}

At the end of the labeling period the growth chambers were removed from the microscope slides, and the cells attached to the slides were fixed with neutral formalin, rinsed in distilled water for one-half hour, and air-dried for further processing.

\section{c. DNA cytophotometry}

The fixed cells were Feulgen stained and cytophotonetry was performed as described (Materials and Methods: B). The ocular had a magnification of 5X. The objective was either a $40 \mathrm{X}$ oil imersion apochromat, numerical aperture (NA) $=1.00$, or a $25 X$ planachromat, NA $=0.45$, and the condensor aperture was set to 0.3 , or 0.24 , respectively. Each cell was scanned three times successively.

\section{d. Autoradiography}

The slides were dipped in Kodak NTB2 1iquid emulsion and exposed in the dark at $4^{\circ} \mathrm{C}$ for four days, after which they were placed for five minutes each in D19 developer and acid fixer. Nuclei were scored as labeled (dividing) if they contained five or more silver grains. A review of autoradiographic techniques is given by Baserga (1967). 


\section{Section II procedure}

a. Cell cultivation and labeling

(1) Effect of ${ }^{3}$ HdT on WI-38 cell growth

Each $25 \mathrm{~cm}^{2}$ Falcon flask received approximately $3 \times 10^{5}$ WI-38 cells. The appropriate amount of ${ }^{3} \mathrm{HdT}$ was added to half the flasks, and the rest of the cultures were controls. At 24 hour intervals the media was removed, the monolayers were washed with $\mathrm{Ca}^{2+}-$ and $\mathrm{Mg}^{2+}$ free PBS, and trypsinized as described (Materials and Methods: A). The cells were pelleted at $500 \mathrm{~g}$, and cell number and volume distribution was determined using the Coulter counter.

(2) Double labeling with ${ }^{3} \mathrm{HdT}$

To determine the optimum labeling conditions two criteria had to be satisfied. First, the growth kinetics of the culture must be unperturbed during a 48 hour exposure to ${ }^{3} \mathrm{HdT}$. Second, three types of cells must be easily discernable by autoradiography: (1) nondividing cells, (2) cells in $S$, and (3) all other dividing cells (i.e., cells in $C_{1}$ or $G_{2}$ phase). The first criterion was satisfied by the procedure described above in (1), "Effect of ${ }^{3} \mathrm{HdT}$ on WI-38 celI growth". The second criterion was satisfied by a double labe 1 technique. Continuous exposure to a very low level of ${ }^{3} \mathrm{HIT}$ labeled the dividing cells. At the end of the labeling period a pulse exposure to a very high level of ${ }^{3} \mathrm{HdT}$ revealed which cells of the dividing population synthesized DNA during the pulse. Preliminary experiments tested various combinations of a continuous exposure to 
${ }^{3} \mathrm{HdT}$ (S.A. $2.0 \mathrm{Ci} / \mathrm{mM}$ ) ranging from 0.1 to $0.0005 \mu \mathrm{Ci} / \mathrm{ml}$, with a pulse of the same S.A. ${ }^{3} \mathrm{HdT}$ ranging from 1.0 to $100.0 \mu \mathrm{Ci} / \mathrm{ml}$. The criteria were optimized when the cells were continuously exposed to $0.003 \mu \mathrm{Ci} / \mathrm{ml}$ $3_{\mathrm{Hdr}}$ for 48 hours and pulsed with $100.0 \mu \mathrm{Ci} / \mathrm{ml}{ }^{3} \mathrm{HdT}$ for 30 minutes.

b. Slide preparation

(1) WI-38 ce11s

For cytophotometric measurements slides were prepared to minimize cellular debris. At the end of the labeling period the radioactive media was decanted from the $T_{25}$ flasks. The cell monolayer was washed two times in $\mathrm{Ca}^{2+}$ - and $\mathrm{Mg}^{2+}$ free PBS, and trypsinized as described (Materials and Methods: $A$ ). The cells were pelleted at $500 \mathrm{~g}$ and suspended in $0.075 \mathrm{M} \mathrm{KCl}$ at room temperature for nine minutes. Finally, the cells were pelleted, decanted, fixed in three changes of methanol: acetic acid (3:1) and dropped on wet, acid-cleaned microscope slides.

The procedure for cleaning slides is as follows. Soak the slides in chloroform: methanol $(3: 1)$ or in a $5 \%$ NaOH-methanol solution for one hour. Place the slides in $\mathrm{HNO}_{3}: \mathrm{H}_{2} \mathrm{SO}_{4}(1: 1)$ for 24 hours. Finally, soak the slides in dilute base for 30 minutes. A 30 minute rinse in distilled water follows each step.

(2) White blood cell standard

Heparinized blood, obtained by venipuncture, was layered over cold flotation media $[2$ parts 18 methylcollulose in $0.8 \%$ saline, 1 part $50 \%$ W/V sodium Hypaque (Winthrop Labs, New York)], and allowed to settle 
for 1 hour at room temperature. The erythrocytes aggregated and sedimented out leaving an upper layer of leukocyte-rich serum, which was decanted and spun in a clinical centrifuge for five minutes at 800 rpm. The leukocyte pellet was resuspended in one tenth the volume of the serun supernatent. A small drop of leukocytes was placed on one end of a microscope slide, which contained previously fixed WI-38 cells, and was gently spread with the short edge of a second slide held at a $45^{\circ}$ angl:. The slide containing the ifI-38 and white blood cells was air-dried, and fixed in neutral farmalin for 30 minutes.

\section{c. DNA cy'ophotometry}

Measurewents were made as described (Materials and Methods: B). The ocular had a magnification of $5 x$. The objective was a $25 x$ planachromat, $N A=0.45$, and the condensor aperture was set to 0.3 . Each cell was scanned once, using tro different clear fields. The standard deviation of the replicate measurements of all WI-38 nuclei measured gave an average of 2.6\%. Approximately 100 cells per culture were measured, 50 cells on each of two days, and the mean was computed. The data from the two days was normalized using white blood cells as a standard, and the measurements were combined to yield a single histogram.

\section{c. Autoradiography}

Autoradiography was performed as described for Section I with the modification that slides from cells double labeled with ${ }^{3}$ HdT were exposed to the emulsion for 18 days. Preliminary experiments in which the exposure $t$ ime was varied from four to 29 days revealed that 18 
days gave the best resolution among nuclei which incorporated high levels of ${ }^{3}$ HdT (s cells), nuclei which incorporated low levels of ${ }^{3} \mathrm{HdT}$ (dividing $G_{1}$ or $G_{2}$ cells) and unlabeled nuclei (nondividing cells).

\section{Premature Chromosome Condensation-Autoradiographic Studies}

The technique of PCC allowed visualization of the chromosomes of nondividing WI-38 cells. The chromosome morphol sgy and number revealed the cell cycle phase and ploidy level of the cells, at the time of fixation of the sample. Cells in $G_{1}$ had single chromatids and cells in $G_{2}$ had paired chromatids. Diplold cells had 46 chromatids and tetraploid cells had 92 chromatids. Autoradiography, used in combination with PCC, allowed the cells to be further classified as nondividing (no incorporation of ${ }^{3} \mathrm{HdT}$ at 48 hours of exposure to the label) or dividing.

A general description of the PCC-autoradiographic procedure is as follows. Tritiated thymidine was added to the WI-38 culture media for 48 hovirs. Colcemid-blocked mitotic HeLa or CHO cells were fused to the WI-38 cells. Chromosone spreads were made of the fusion mixture. Approximately 100 mapped cells with PCC for each culture were located. The chromosone constitution was analyzed to identify the cycle phase and ploidy level of the colls. Finally, the slides were dipped in enulsion for autoradiographic decection of ${ }^{3}$ HdT uptake of the sane cells. These experiments are presented in Section III. 


\section{Section III procedure}

a. Cell cultivation and labeling

(1) WI-38 cells

WI-38 cells were seeded at a density of $1.3 \times 10^{4} \mathrm{cells} / \mathrm{cm}^{2}$ in Falcon flasks and incubated at $37^{\circ} \mathrm{C}$. Twenty four hours later, 0.1 $\mu \mathrm{Ci} / \mathrm{ml}^{3} \mathrm{HdT}(\mathrm{S}, \Lambda, 2,0 \mathrm{Ci} / \mathrm{MM})$ was added to the cultures and left for 48 hours.

\section{(2) $\mathrm{CHO}$ cells}

Mitotic Cllo cells were prepared by the method of Terasima and Tolmach (1963). When cells cultured in monolayer enter mitosis they round up and adhere much less firmly to the surface than interphase cells. Gentle agitation will selectively detach mitotic cells. Twenty-four hours after CHO cells were seeded in a roller bottle at a density of $4 \times 10^{4} \mathrm{cells} / \mathrm{cm}^{2}$, the media was removed and the monolayer washed twice to remove dead cells and debris. Fresh media containing Colcemid $(0.06 \mu g / m l)$ was added to accumulate cells in mitosis (Stubblefield and Klevecz, 1965). At appropriate times, the bottle was rolled gently on a horizontal surface, the media containing detached cells was decanted and placed on ice, and fresh media with Colcemid was added to the culture. Samples were analyzed for cell number and volume using a Coulter counter with a volume spectrometer, and for mitotic index. The mitotic index of the pooled aliquots was 91\%. CHO cells did not produce PCC, therefore, Hela cells were used for further experiments. 


\section{(3) HeLa cells}

Hela cultures were grown in suspension culture, until transferred to monolayer culture one week prior to use for cell fusion. The cells were labeled with $0.1 \mu \mathrm{Ci} / \mathrm{ml}^{3} \mathrm{HdT}$ (S.A. $2.0 \mathrm{Ci} / \mathrm{mM}$ ) for 26 hours and for the final 20 hours of labeling, Colcemid (final concentration 0.25 $\mu g / m i)$ was added to block mitosis. The unattached, arrested mitotic cells were collected by decanting and centrifugation. The mitotic index of these cells averaged $99.9 \%$ and the percentage of mitoses that were labeled was 99.7.

b. Cell fusion

(1) Fusion in monolayer

The method described by Harris et a‥, (1966) for cell fusion was utilized with minor modifications. WI-38 cells $\left(5 \times 10^{4}\right)$ were seeded per Lab-Tek microscope slide chamber $\left(4 \mathrm{~cm}^{2}\right)$. Twenty-four hours later the media was renoved and replaced with cold $\alpha-M E M$, without serum, buffered at pH 7.0 with HEPES ( $N^{\prime}-2$-Hydroxymethylpiperazine-N'Ethanesulfonic Acid). The monolayers were chilled on ice for five minutes. B-propiolactone-inactivated Sendai virus was added to the media to a final concentration of 10,000 hemagglutinating units (HAUs) per $\mathrm{ml}$, and allowed to absorb to the monolayer for 30 minutes at $4^{\circ} \mathrm{C}$. (The virus was kindly supplied by Dr, Larry Thompson, Lawrence Livermore Laboratory, Livernore, California.) The excess virus was removed and $5 \times 10^{5}$ mitotic Hela cells in $0.5 \mathrm{ml}$ medium, without serum, were added to each chamber. The slide chambers were incubated 
at $37^{\circ} \mathrm{C}$ and aftor 30 minutes, one hour, four hours and six hours of incubation, samples were washed with media and fixed in Carnoys. No cells with PCC were observed, therefore, cells were fused in suspension for a11 further experiments.

\section{(2) Fusion in suspension}

The method described by Johnson and Rao for PCC (Tohnson and Rao, 1970; Rao and Johnson, 1972) was utilized with minor modifications. Preliminary experiments were performed to test the effects of $\mathrm{pH}$, virus and cell concentration. The highest percentage of PCC was abtained when $0.5 \times 10^{6}$ cells of each type (WI-s 8 and mitotic HeLa) were placed in a total volume of $0.5 \mathrm{ml}$ of medium, wi hout serum, buffered at pll $7.3 \mathrm{with}$ HEPES (N'-2-Hydroxyethylpiperazine-N'Ethanesulfonic Acid) containiug 250 hemagglutinating units of b-propiolactone-ingctivated Sendai virus, (The Sendai virus was genecously donated by Dr. Barbara B. Knowles, listar Institute, Philadelphii, Pennsylvania.) The virus-cell mixutre was kept at $4^{\circ} \mathrm{C}$ for 20 minutes and then at $37^{\circ} \mathrm{C}$ for 45 minutes.

\section{c. Slide preparation and chromosome identification}

Chromosome preparations were made by exposing the cell mixture to hypotonic $\mathrm{KCl}(0.075 \mathrm{M})$ at room temperature for 10 minutes, fixing and washing in three changes of methanol: acetic acid ( $3: 1)$, and dropping the cells on wet microscope slides. Cells showing PCC were first located with phase optics, or with bright field after staining with $2 \%$ aceto-orcein. Chromosome complements were identifipd as $G_{1}$, if the 
condensed chromatin contained a single chromatid, or $G_{2}$, if paired chromatids were present. Those in $S$ were identifled by their unevenly condensed chromatin, but since few could be unambiguously discerned they were not included in this study. The prematurely condensed chromosames were counted and their complements were further classified as either "diploid" (2N) or "tetraploid" (4N) (where $N$ is the number of chromosomes in a haploid nucleus, in this case 23). In some cases the counts could on $2 y$ be estimated to $\pm 20 \%$, due to overlapping of the highly extended chromosomes.

\section{d. Autoradiography}

The slides were dipped in Kodak NTB2 liquid emulsion, exposed for four days, developed, fixed, and stained in a $7.5 \%$ Giemsa solution. The preclassified PCC cells were relocated and identified as labeled (dividing) or unlabeled (nondividing). 


\section{RESULTS}

\section{A. Cytophotometric-Autoradiographic Studies}

DNA cytophotometry- ${ }^{3}$ HdT autoradiography was utilized in section I to determine the position in the cycle of nondividing $\| I-38$ cclls from culturcs of various ages. Section II presents a refinement of the techniques used in Section I. Neasurements were made on cells whose growth kinetics were unperturbed, Slides were prepared to diminish cellular debris. In addition, the cells were double labeled with ${ }^{3}$ HdT' to determine the precise boundary of cells in $G_{1}, S$ and $G_{2}$ for analysis of coefficient of variation (standard deviation/mean) of DNA values. Section II also describes the growth kinetics of tells exposer' to various levels of $3_{\text {hidr. }}$ 1. Section I

lnitial experiments to identify the cell sycle stuge of nondiliding $K I-38$ cells are presented in this section. Feulgen DNA stain content was quantified in fixed, single cells following continuous exposure to ${ }^{3} \mathrm{HdT}(0.1+\mathrm{Cj} / \mathrm{ml}, 5 . A .2 .0 \mathrm{Cj} / \mathrm{mM})$ for 48 hours. Autoradiographic detection of $\vec{j}_{\mathrm{HdT}}$ uptake (proliferative status) subsequently was correlated with DNA stain content.

a. DNA cytophotometry of dividing and nondividing cells Cycophotometric-autoradiographic measurements made un six lil-38 cultures of various ages are presented in the form of histograms (frequency distributions) in figure 1. Each histogram is divided into labeled (dividing) and unlabeled (nondividing) cells. The histograms 
Figure 1. Feulgen DNA stain content of aging WI-38 cultures. The histograms are arranged according to increasing age (percent unlabeled nuclei). The stippled bars represent the labeled cells $\left(0.1 \mu \mathrm{Ci} / \mathrm{ml}{ }^{3} \mathrm{HdT}, \mathrm{S} . \mathrm{A} .2 .0 \mathrm{Ci} / \mathrm{mM}\right.$ for 48 hours) and the clear bars represent the unlabeled cells. DNA content is given in arbitrary CYDAC units (ACU) of $\mathrm{C}$ where $2 \mathrm{C}$ is the diploid DNA content, operationally defined in terms of the mode of first peak. 

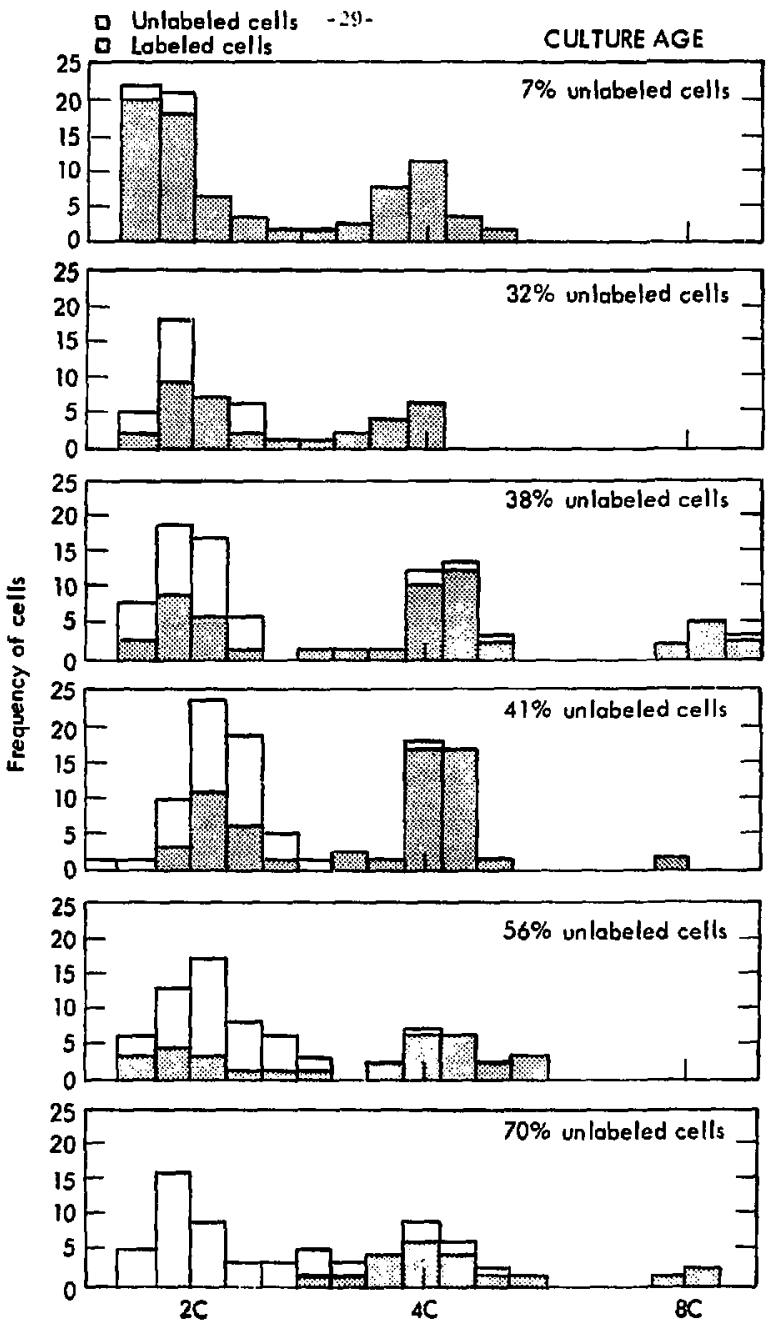

jigure 1. Log DNA stain content (ACU) 
are arranged according to increasing culture age, as defined by percent unlabeled cells (Cristofalo and Sharf, 1973).

The histogram of the youngest culture ( $7{ }^{\circ}$ unlabeled cells) is characteristic of a grawing diploid population. The Feulgen DNA values are distributed into two peaks with an intervening plateau. The first peak, called the $2 C$ peak, has a DNA content similar to a single pole of a cell in anaphase, while the second peak, called the 4C peak, has a DNA content similar to a cell in metaphase. As expected, the DNA content of the $2 \mathrm{C}$ peak is approximately half that of the $4 \mathrm{C}$ peak. These observations indicate that the $2 \mathrm{C}$ and $4 \mathrm{C}$ peaks represent diploid $G_{1}$ and liploid $G_{2}$ cells, and that the intervening plateau represents $S$ cells. There are more labeled cells in the $2 \mathrm{C}$ peak than in the $4 C$ peak since each $G_{2}$ cell becomes two $G_{1}$ cells as it passes through the point of division.

The majority of the cells in the youngest culture incorporated

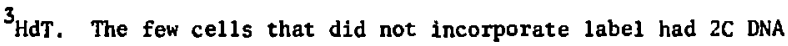
contents, and therefore, were blocked in the diploid $G_{1}$ phase.

The histogram of the culture containing $32 \%$ unlabeled cells has a similar profile to the youngest culture, except that there are fewer labeled cells in $G_{1}, S$ and $C_{2}$. The histogram is bimodal and the culture is presumed to be diploid. The unlabeled cells have 2C DNA contents.

The histogram of the culture with $38 \%$ unlabeled cells has a third peak of DNA values at $8 \mathrm{C}$, which indicates that the culture contains 
polyploid cells. In contrast to the two younger cultures, this culture has more labeled $4 \mathrm{C}$ cells than labeled $2 \mathrm{C}$ cells, which suggests that the growth kinetics of the cycling cells are disturbed. Similar to the younger cultures, most unlabeled cells have $2 \mathrm{C}$ DNA contents. However, a few unlabeled cells have $4 \mathrm{C}$ DNA contents and one cell has an 8C DNA content, The occurance of polyploid cells complicates the interpretation of the histogram because DNA cytophotometry cannot deternine whether the unlabeled cells with $4 \mathrm{C}$ DNA contents are $G_{2}$ cells from a diploid population or are $G_{1}$ cells from a tetraploid population. (This problem is addressed in Section III.) Analogously, the unlabeled $8 \mathrm{C}$ cells could be either $G_{1}$-blocked octaploid cells or $\mathrm{G}_{2}$-blocked tetraploid cells.

With further increasing culture age there is progressive deviation from the DNA listribution of the vigorously growing young culture. Cultures containing $41 \%, 56 \%$ and $70 \%$ unlabeled cells have polyploid cells, and few or no proliferating $S$ cells. The fraction of labeled cells with 2C DNA content declines with age, while the fraction of labeled cells with 4C DNA content increases. The most extreme example is the oldest culture (70\% unlabeled cells) where, for this sample, there are no labeled $2 \mathrm{C}$ cells; labeled cells have either $4 \mathrm{C}$ DNA or $8 \mathrm{C}$ DNA. In this senescent culture, it is possible that the entire proliferating subpopulation is either in the $G_{2}$ phase or is polyploid. In all cultures the majority of unlabeled cells have $2 \mathrm{C}$ DNA contents but with increasing culture age there is an increased frequency of unlabeled $4 \mathrm{C}$ cells. 
An interesting age-correlated observation is the progressive dispersion of DNA stain content in the two peaks, $2 \mathrm{C}$ and $4 \mathrm{C}$, especially for nondividing cells. "Noisy" DNA stain content could reflect aneuploid DNA content, which could lead to cell arrest. One would expect, therefore, that the dispersion of DNA values would be greater for old cultures as compared to young cultures, and for nondividing cells as compared to dividing cells. It is difficult to quantitate the peak dispersion (i,e., calculate the coefficient of variation or $(\mathrm{V})$ because the boundary between the peaks and the plateau is arbitrary. Experiments in Section II were designed to identify cells in the plateau (i.e., cells in $S$ phase) in order to permit calculation of the $C V$.

In summary, most unlabeled cells from aging WI-38 cultures have $2 \mathrm{C}$ DNA values. Unlabeled $4 C$ cells appear increasingly with the age of the culture. These may be cells arrested in diplaid $\mathrm{G}_{2}$ or tetraploid $G_{1}$ phase. Experiments described in Section III were designed to resolve this enigma. Most labeled cells in aging cultures have $4 \mathrm{C}$ DNA values, whereas most labeled cells in young cultures have 2C DNA values. Experiments in Section II suggest an explanation for the increase in labeled $4 \mathrm{C}$ cells. In addition, old cultures have labeled and unlabeled polyploid (8C) cells. Finally, there may be an increased dispersion of DNA values for 2C or 4C cells of older cultures. This may be more pronounced for nondividing cells. A quantitative approach to determine the dispersion of DNA values is exploited in Section II. 


\section{Section II}

Experiments in Section I indicated that old WI-38 cultures have a greater dispersion of DNA contents at the $2 \mathrm{C}$ and $4 C$ levels than young cultures. Experiments in this section involved cytophotometric-autoradiographic methods which allow identifcation of $S$ phase cells and thus permits a quantitative evaluation of the dispersion.

An increased dispersion of DNA values could be due to aneuploid DNA content. Several lines of evidence (e.g., Levisohn and Thompson, 1973; Prescott, 1975) suggest that somatic cell division, as well the aging process (e.g., Crowley and Curtis, 1963; Curtis, 1963) are regulated at the chromosomal level. It is conceivable that at mitosis, uneven partitioning of chromosomes which carry genes involved in cell reproduction, could cause cell arrest. One would expect, therefore, that old cells would have a greater $\mathrm{CV}$ of DNA values than young cells (i.e., would be more aneuploid), and that nondividing cells would have a greater CV of DNA values than dividing cells.

DNA histograms in Section I could not be analyzed for CV because of uncertainty in the boundaries between the peaks and the plateau. Experiments in this section were designed to identify cells in the plateau (i.e., cells in S) and thus identify the boundaries of the ptaks. Cultures were exposed for 48 hours to a low concentration of 3HdT $(0.003 \mu \mathrm{Ci} / \mathrm{ml}, \mathrm{S} . \mathrm{A} .2 .0 \mathrm{Ci} / \mathrm{mM})$ in order to label cycling cells. This was followed by a 30 minute pulse with high concentrations of 
${ }^{3} \mathrm{HdT}(100 \mu \mathrm{Ci} / \mathrm{ml}, \mathrm{S} . \mathrm{A} .2 .0 \mathrm{Ci} / \mathrm{mH})$ to label cells in the $\mathrm{S}$ phase. DNA cytophotometry was performed on fixed, single nuclei followed by autoradiographic detection of ${ }^{3}$ HdT uptake. S phase nuclei were heavily labeled, cycling $G_{1}$ and $G_{2}$ nuclei wore lightly labeled, and noncycling nuclei were unlabeled. The $S$ phase nuclei were subtracted from the DNA histograms of the total nuclei to yield $2 \mathrm{C}$ and $4 \mathrm{C}$ peaks. Finally, the $\mathrm{CV}$ of the $2 \mathrm{C}$ and $4 \mathrm{C}$ peaks was calculated and compared for old and young cells, and for dividing and nondividing cells.

\section{a. Effect of ${ }^{3}$ HdT on WI-38 cell keowth}

Preliminary to the cytophotometric experinents, the effect of continuous exposure to varied levels of ${ }^{3} \mathrm{HdT}$ on cell growth was exanined. Cells were exposed to the varlous ${ }^{3} \mathrm{HdT}$ concentrations that were used for cytophotonetric experiments. Cell growth was monitored during continuous exposure to low levels of ${ }^{3} \mathrm{HdT}(0.1 \mu \mathrm{Ci} / \mathrm{ml}$ or $0.003 \mu \mathrm{Cl} / \mathrm{ml}, \mathrm{S} . \mathrm{A}, 2.0 \mathrm{Ci} / \mathrm{mm})$, and to high levels of ${ }^{3} \mathrm{HdT}(1.0 \mu \mathrm{Ci} / \mathrm{ml}$ or $5.0 \mu \mathrm{Ci} / \mathrm{ml}$, S.A. $20.0 \mathrm{Ci} / \mathrm{mM}$. Use of each concentration of ${ }^{3} \mathrm{HdT}$ is described in brief. Uptake of $0.1 \mu \mathrm{Ci} / \mathrm{ml}{ }^{3} \mathrm{HdT}$ defined dividing cells in Section I. Uptake of $0.003 \mu \mathrm{Cl} / \mathrm{ml}^{3} \mathrm{HdT}$ defined dividing cells in Section II. This low concentration of ${ }^{3} \mathrm{HdT}$ was used so that: (1) the growth kinetics of cells which incorporate label were unperturbed and thus did not distort the data analysis; (2) cel1s which incorporated Low concentrations of ${ }^{3} \mathrm{HdT}$ during continuous exposure were easy to distinguish autoradiographically from cells which were pulse labeled with high concentrations of ${ }^{3} \mathrm{HdT}$. Other cultures were grown in the 
presence of $1.0 \mu \mathrm{Ci} / \mathrm{ml}^{3} \mathrm{HdT}$ or $5.0 \mu \mathrm{Ci} / \mathrm{mI}^{3} \mathrm{HdT}$ and thereby were enriched for nondividing cells.

(1) Labeling with low levels of ${ }^{3} \mathrm{HdT}$

In section I nondividing $1 / \mathrm{I}-38$ cells were cells which did not incorporate $0.1 \mathrm{LCi} / \mathrm{ml}^{3} \mathrm{HdT}$ (S.A. $2.0 \mathrm{Ci} / \mathrm{mM}$ ) at 48 hours of exposure. Cristofalo and Sharf (1973) reported that the LI of cells exposed to this ${ }^{3}$ HdT concentration reached a plateau at 24-30 hours. In a well behaved system the LI should not plateau, but should asymptote toward 100 t as the dividing (labeled) popuiation increases by proliferation. The behavior of cells grom with and without label $\left(0.1 \mu \mathrm{Ci} / \mathrm{ml}{ }^{3} \mathrm{HdT}\right.$ or $0,003 \mu \mathrm{Ci} / \mathrm{ml}{ }^{3} \mathrm{HdT}, \mathrm{S} . \mathrm{A} .2,0 \mathrm{Ci} / \mathrm{m}(\mathrm{M})$ was monitored by cell number and Coulter volume.

Figure 2 shows that cellular proliferation is inbibited by $0.1 \mathrm{HCi}$ $\mathrm{ml} 3 \mathrm{HdT}$ and is not inhibited by $0.003 \mu \mathrm{Ci} / \mathrm{ml}{ }^{3} \mathrm{HdT}$. The cell number of the control (no ${ }^{3} \mathrm{HdT}$ ) increases linearly with time after seeding the culture, until 72 hours. At this time the cell, imber reaches a plateau as the result of density dependent inhibition. The culture with $0.003 \mathrm{HCi} / \mathrm{ml} 3^{3} \mathrm{HdT}$ shows no significant difference in cell number from the control culture for the duration of the experiment. The culture exposed to $0.1 \mu C 1 / m l 3^{3}$ IdT has the same cell number as the control for the first 24 hours of labeling. At 48 hours of ${ }^{3}$ HdT exposure $\left[0,1 \mu \mathrm{Ci} / \mathrm{ml}{ }^{3} \mathrm{HdT}\right.$ ] there are significantly fewer cells than in the control culture. The cell number is unchanged during the remainder of the labeling period. These results may be explained by inhibition of cell division. In addition, cell death may occur. 
Figure 2. Effect of continuous exposure to low levels of ${ }^{3} \mathrm{HdT}$ $(2.0 \mathrm{Ci} / \mathrm{m})$ on WI-38 cell growth, The boldface arrow indicates the time of addition of $0.1 \mu \mathrm{Cl} / \mathrm{ml}{ }^{3} \mathrm{HdT}$ or of $0.003 \mu \mathrm{Cl} / \mathrm{ml}^{3} \mathrm{HdT}$. 


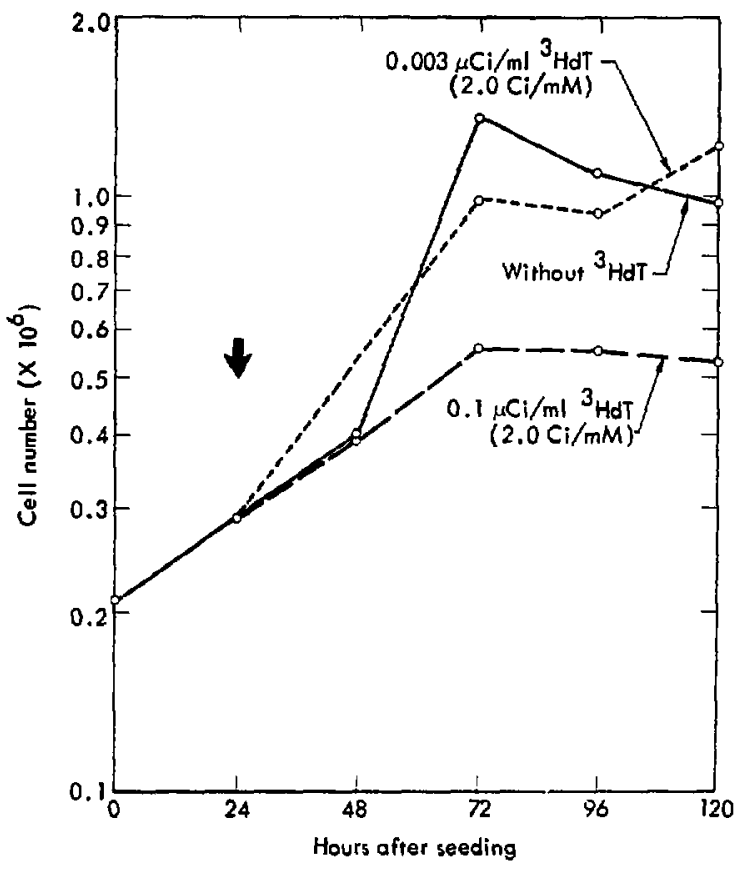

Figure 3 . 
Figure 3 shows that $\mathrm{LI}$ is inhibited by continuous exposure to 0.1 $\mu \mathrm{Ci} / \mathrm{ml}^{3}{ }^{3} \mathrm{HdT}$. The LI reaches a plateau at 48 hours of ${ }^{3} \mathrm{HdT}$ exposure. Coulter volume distributions are shown in figure 4 . The control culture has a distribution which is skewed toward the right. Small cells, which predominate, appear on the left side, and the larger cells tail off toward the right. This distribution is typical of an asynchronous log-phase population, in which the age distribution decreases exponentially from birth (small cells) to mitosis (large cells). At the extreme left, a slight rise in the curve occurs due to the presence of cellular or other debris. Cells which we:e exposed to $0.003 \mu \mathrm{Ci} / \mathrm{ml}^{3} \mathrm{HdT}$ for four days have a volume distributios similar to the control culture (figure 4; day 5). Cells which were exposed to $0.1 \mu \mathrm{Ci} / \mathrm{ml}^{3}{ }^{3} \mathrm{HdT}$ for four days have a broad volume distribution which is shifted to the right, indicatiug that these cells are larger than the control cells. The increase in cellular volume may be due to cells which are blocked in diploid $G_{2}$ or tetraploid $G_{1}$, and which may have unbalanced growth.

Table 1 shows the modal channel numbers of the Coulter volume of cells grown with and without ${ }^{3} \mathrm{HdT}$. The modal channel number of the control and of the culture with $0,003 \mu \mathrm{Ci} / \mathrm{ml}^{3}{ }^{3} \mathrm{HT}$ shows ro significant change with time. The modal channel number of the culture with 0.1 $\mu \mathrm{Ci} / \mathrm{ml}^{3} \mathrm{HdT}$ increases to approximetely one and one-naif times the control culture, at four days of labeling (or day 5).

To determine if $0.003 \mu \mathrm{Ci} / \mathrm{ml}^{3} \mathrm{HdT}$ affects the growth of cultures of various ages, cells were grown in the presence and absence of ${ }^{3} \mathrm{HdT}$. 
Figure $3 . \quad$ Labeling index of WI-38 cells continuously exposed to low levels of ${ }^{3} \mathrm{HdT}(2.0 \mathrm{Ci} / \mathrm{mM})$. The boldface arrow indicates the time of addition of $0.1 \mu \mathrm{Ci} / \mathrm{ml}^{3} \mathrm{HdT}$. 
$-40-$

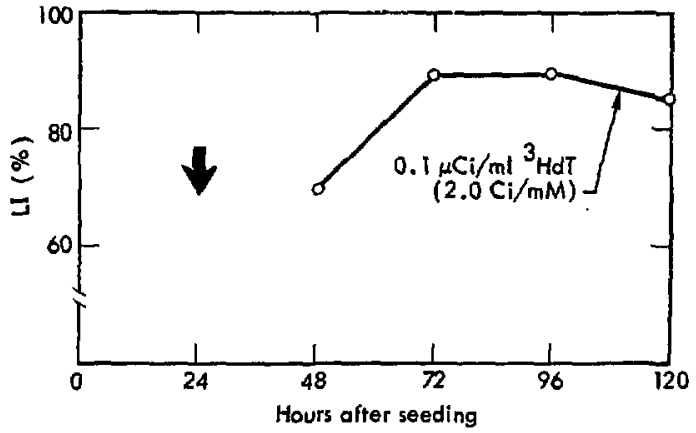

Figure 3. 
Figure 4. Coulter volune distribution of WI-38 cells continuously exposed to low levels of ${ }^{3} \mathrm{HdT}(2.0 \mathrm{Ci} / \mathrm{mM})$. The label $\left(0.1 \mathrm{\mu Cl} / \mathrm{ml}^{3} \mathrm{HdT}\right.$ or $\left.0.003 \mathrm{HCl} / \mathrm{ml}^{3} \mathrm{HdT}\right)$ was added on day 1. 

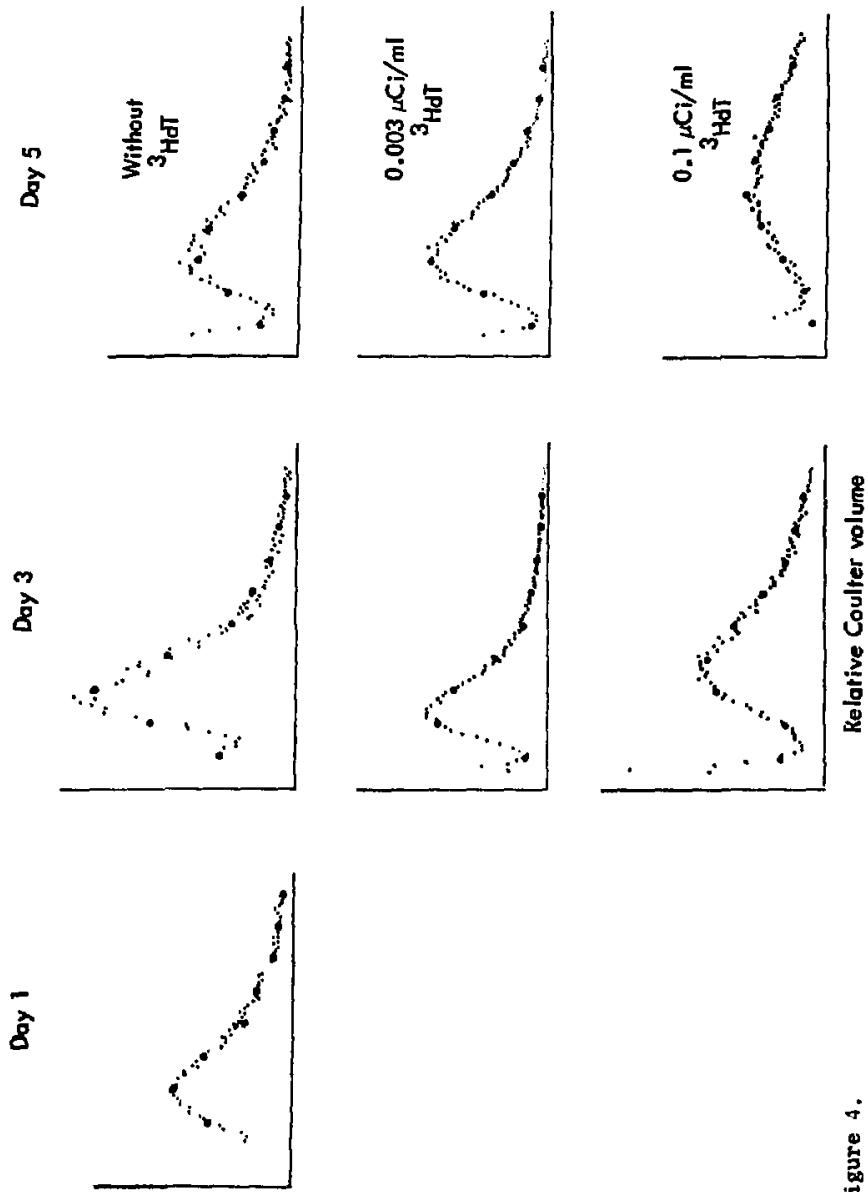

dequnu $11^{00}$ ox!dopey 
MODAL CHANNEL OF COULTER VOLUMES OF WI-38 CELLS GROWN WITH AND WITHOUT $2.0 \mathrm{Ci}^{\mathrm{m}} \mathrm{m}^{3} \mathrm{HdT}$

\begin{tabular}{|c|c|c|c|}
\hline \multirow{2}{*}{ Doy a } & \multicolumn{3}{|c|}{ Modal channel number } \\
\cline { 2 - 4 } & $\begin{array}{c}0.1 \mu \mathrm{Ci} / \mathrm{ml} \\
3 \mathrm{HdT}\end{array}$ & $\begin{array}{c}0.003 \mu \mathrm{Ci} / \mathrm{ml} \\
3_{\mathrm{HdT}}\end{array}$ & $\begin{array}{c}\text { Without } \\
3_{\mathrm{HdT}}\end{array}$ \\
\hline 0 & - & - & 37 \\
\hline $\mathrm{j}^{\mathrm{b}}$ & - & - & 40 \\
\hline 2 & 40 & 41 & 39 \\
\hline 3 & 49 & 34 & 37 \\
\hline 5 & 60 & 43 & 39 \\
\hline a. Doy after seeding the culture & \\
b. Time of addition of ${ }^{\mathrm{HdT}}$ & & \\
\hline
\end{tabular}

able 1. 
Growth curves of young, middle-aged, and old cultures (figures 5, 6 and 7 respectively) show an initial lag period followed by a rise in cell number which is, as expected, steeper for the young and middle-aged cultures than for the old culture, At all ages, the control and ${ }^{3}$ HdT-labeled curves show identical growth kinetics, within 95\% confidence limits, therefore this ${ }^{3} \mathrm{HdT}$ concentration does not retard growth.

In sumary, these data show that cellular growth is inhibited by continuous exposure to $0.1 \mathrm{\mu Ci} / \mathrm{ml}$ (S.A. $2.0 \mathrm{Ci} / \mathrm{ms}$ ). During the first 24 hours of labeling the cell number increases at a rate similar to the control. At 48 hours of labeling the cell number is significantly less than the control. Nfter 48 hours the cell number reaches a plateau. This indicates that the plateau of LI after 48 hours of ${ }^{3} \mathrm{HdT}$ exposure may be explained by the inhibition of division. By 120 hours of labeling the cell volune ts approximately one and one-half times the control. This may be due to cells which are blocked in diploid $G_{2}$ or tetraploid $C_{\text {, }}$ and which may undergo unbalanced growth. On the other hand, cellular erowth is not affected by continuous exposure to $0.003 \mu \mathrm{Cj} / \mathrm{al}{ }^{3} \mathrm{HdT}$ (S.A. $2.0 \mathrm{Ci} / \mathrm{mM}$ ). There is no difference in cell nuaber for control cells and cells exposed to $0.003 \mu \mathrm{Cl} / \mathrm{al}$, regardless of the age of tho culture.

(2) Label ing with high levels of ${ }^{3} \mathrm{HdT}$

Cellular growth was exanined for WI-38 cultures grown in the presence and absence of $1.0 \mathrm{\mu Ci} / \mathrm{ml}^{3} \mathrm{HdT}(\mathrm{S} . \mathrm{A} .20 .0 \mathrm{Ci} / \mathrm{m}$ ) or $5.0 \mathrm{\mu Ci} / \mathrm{al}$ 
$-45-$

Figure 5. Effect of continuous exposure to low levels of ${ }^{3} \mathrm{HdT}$ (2.0 Ci/nd) on young WI-38 culture growth. The PDL of this culture was 30 . The boldface arrow indicates the time of addieton of $0.003 \mathrm{wCi} / \mathrm{ml}^{3} \mathrm{HdT}$. 


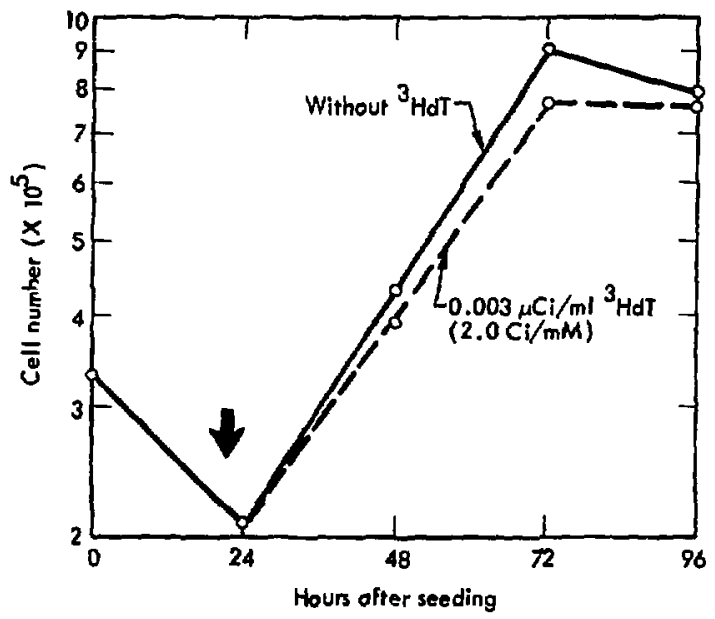

Figure 5. 
Figure 6. Effect of continuous exposure to low levels of ${ }^{3} \mathrm{HdT}$ (2.0 Ci $\left./ m^{4}\right)$ on middle-aged WI-38 culture growth. The POL of this culture was 47 . The boldface arrow indicates the time of addition of $0.003 \mu \mathrm{Cl} / \mathrm{ml}^{3} \mathrm{HdT}$. 


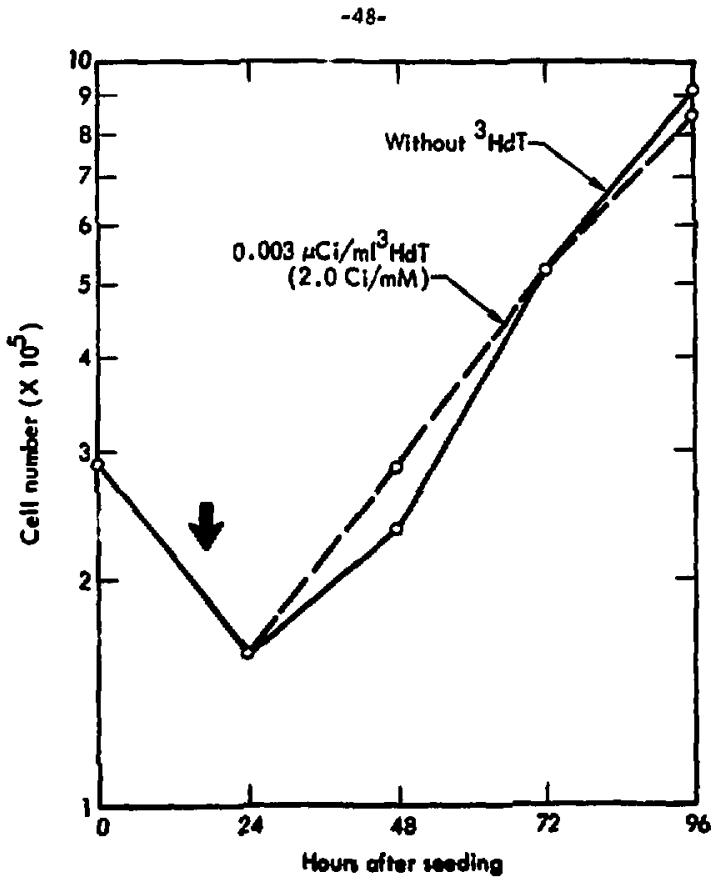

Figure 6. 
Figure 7. Effect of continuous exposure to low levels of ${ }^{3} \mathrm{HdT}$ (2.0 Ci/ms) on old WI-38 culture growith. The PDL of this culture was 53. The boldface arrow indicates the time of addition of $0.003 \mathrm{\mu CI} / \mathrm{ml}{ }^{3} \mathrm{HLT}$. 


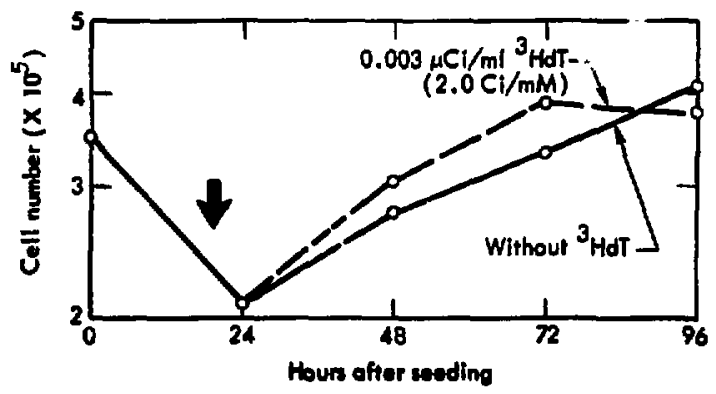

Figure 7. 


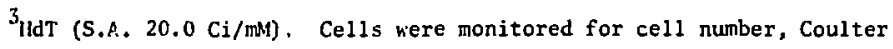
volume and $\mathrm{LI}$.

Figure 8 shows that cellular proliferation is inhibited by continuous exposure to $1.0 \mu \mathrm{Ci} / \mathrm{ml}^{3} \mathrm{HITT}$. The cell number of the control (no ${ }^{3}$ HdT) increases Iinearly with time after seeding the culture. The cell number of the cul with ${ }^{3} \mathrm{HdT}$ increases at a linear rate, which is slightly less ..... the control, for the first 24 hours of labeling. The cell number is unchanged during the following 24 hours of labeling.

Figure 9 shows that $L I$ is inhibited by continuous exposure to 1.0 $\mu \mathrm{Ci} / \mathrm{ml}{ }^{3}$ lidT. The $\mathrm{LI}$ does not increase significantly from 24 hours to 72 hours after the addition of 5 JldT.

Table 2 show's that cellular volume is increased by exposure to the

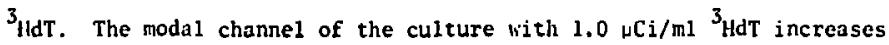
by approximately two times the control at 48 hours of exposure or day 3.

Figure 10 shows that $5.0 \mu \mathrm{Ci} / \mathrm{ml}^{3} 3_{\mathrm{HdT}}$ also inhibits cellular proliferation. The cell number of the control increases linearly with time after seeding tho culturc. The labeled culture has the same cell number as the control at 24 hours of exposure to ${ }^{3}$ lld Th. There is no further increase in cell number for the labeled culture $f$ the duration of the experiment.

Figure $\| 1$ show's that $L I$ is inhibited by continuous exposure to 5.0 $\mathrm{WCi} / \mathrm{ml}$ 3luT. During the first 24 hours of labeling, $84 \%$ of the cells 
Figure 8, Effect of continuous exposure to high levels of ${ }^{3} \mathrm{HdT}$ $(20.0 \mathrm{Ci} / \mathrm{mi})$ on old WI-38 culture growth. The PDL of this culture was 53. The boldface arrow indicates the time of addition of $1.0 \mu \mathrm{Ci} / \mathrm{ml}{ }^{3} \mathrm{HdT}$. 


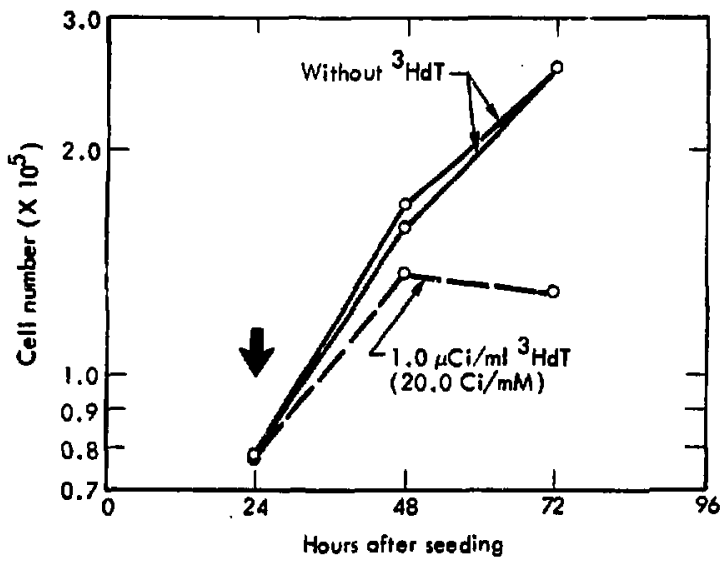

ligure 6 . 
Figure 9. Labeling index of WI-38 cells continuously exposed to high levels of $3 \mathrm{HdT}(20.0 \mathrm{ci} / \mathrm{mH})$. The PDL of this culture was 42 . The boldface arrow indicates the time of addition of $1.0 \mathrm{Ci} / \mathrm{mi}^{3} \mathrm{HdT}$.

Figure 11. Labeling index of WI-38 cells continuously exposed to high lovels of ${ }^{3} \mathrm{HaT}(20,0 \mathrm{cl} / \mathrm{M})$. The PDL of this culture was 46 . The boldface arrow indicates the time of addition of $5.0 \mathrm{\mu Ci} / \mathrm{ml}{ }^{3} \mathrm{HdT}$. 
$.53-$

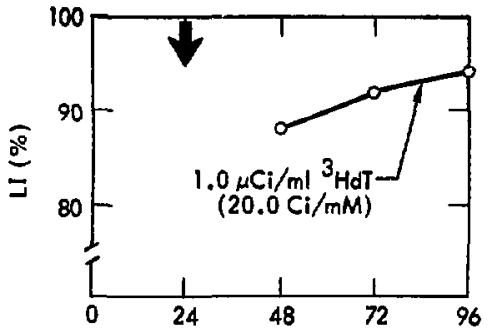

ligure 9.

Hours after seeding

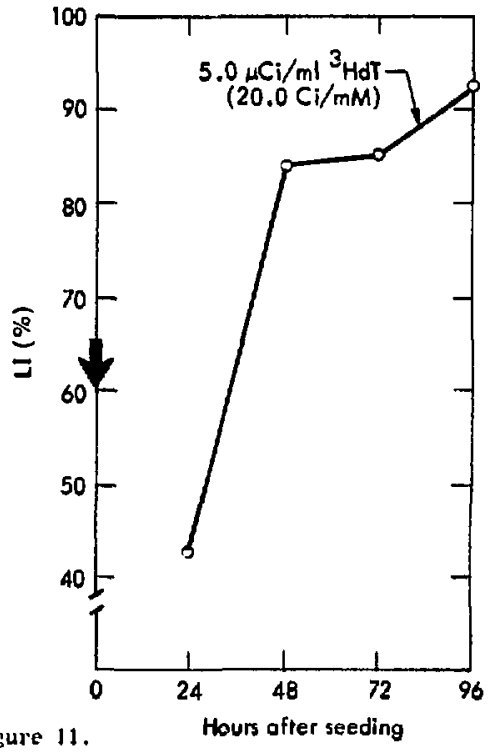


MODAL CHANNEL OF COULTER YOLUMES OF WI-38 CELLS GROWN WITH AND WITHOUT $20.0 \mathrm{Ci} / \mathrm{mM}^{3} \mathrm{HdT}$

\begin{tabular}{|c|c|c|}
\hline \multirow{3}{*}{ Day $a$} & \multicolumn{2}{|c|}{ Modal channel } \\
\cline { 2 - 3 } & $\begin{array}{c}\text { Without } \\
3_{\mathrm{HdT}}\end{array}$ & $\begin{array}{c}1.0 \mu \mathrm{Cl} / \mathrm{ml} \\
3_{\mathrm{HdT}}\end{array}$ \\
\hline $1^{\mathrm{b}}$ & - & - \\
\hline 2 & 31 & 40 \\
\hline 3 & 26 & 54 \\
\hline
\end{tabular}

a. Days after seeding the culture

b. Time of addition of ${ }^{3} \mathrm{HdT}$

Table 2.

MODAL CHANNEL OF COULTER VOLUMES OF WI. 38 CELLS GROWN WITH AND WITHOUT $20.0 \mathrm{Ci} / \mathrm{mM} 3 \mathrm{HdT}$

\begin{tabular}{|c|c|c|}
\hline \multirow{2}{*}{ Day a } & \multicolumn{2}{|c|}{ Modal channel } \\
\cline { 2 - 3 } & $\begin{array}{c}\text { Without } \\
3 \mathrm{HdT}\end{array}$ & $\begin{array}{c}5.0 \mu \mathrm{Ci} / \mathrm{ml} \\
3_{\mathrm{HdT}}\end{array}$ \\
\hline $0^{\mathrm{b}}$ & 24 & 23 \\
\hline 1 & 29 & 28 \\
\hline 2 & 30 & 56 \\
\hline 3 & 28 & 78 \\
\hline 4 & 26 & 117 \\
\hline a. Days afrer seeding the culture \\
b. Time of addition of ${ }^{3} \mathrm{HdT}$ \\
\hline
\end{tabular}

Table 3. 
Figure 10. Effect of continuous exposure to high levels of ${ }^{3} \mathrm{HdT}$ $(20.0 \mathrm{Ci} / \mathrm{ml})$ on $1 \mathrm{I}-38 \mathrm{ce} 11$ growth. The PDL of this culture was 46 . The boldface arrow indicates the time of addition of $5.0 \mu \mathrm{Ci} / \mathrm{ml}^{3} \mathrm{HdT}$. 


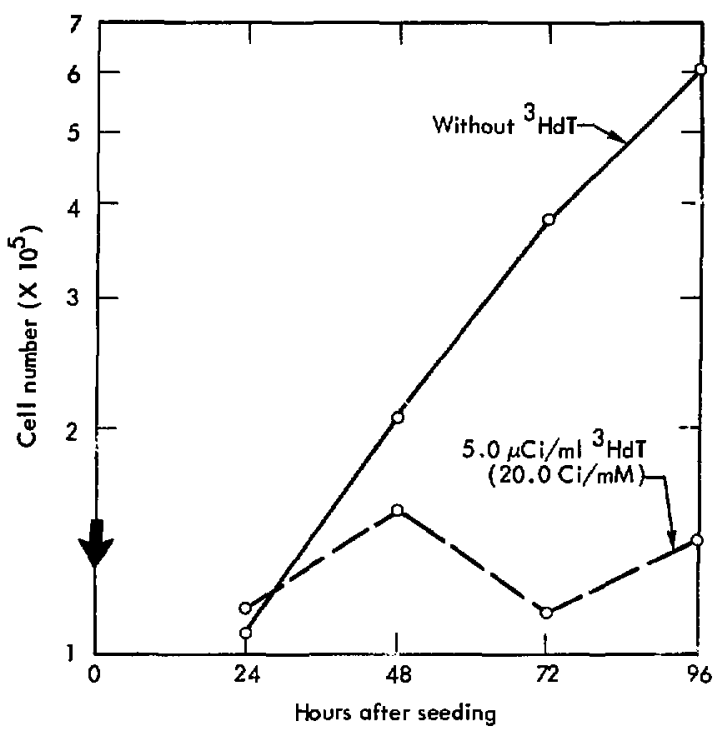

Figure 10. 
incorporate ${ }^{3}$ IIdT, At 72 hours of labeling there is no change in $\mathrm{LI}$ and at 96 hours there is a slight, but statistically insignificant, rise in LI. The LI approximately doubles from 24 to 48 hours of ${ }^{3} \mathrm{HdT}$ exposure, whereas the cell number (figure 10) remains constant. These results may be explained by the occurence of cells which incorporate $3_{\text {HdT }}$ and then do not proceed through division $\left(\mathrm{G}_{2}\right.$-blocked cells). Also, cell death from ${ }^{3}$ EIdT exposure could contribute to the plateau of ce11 number.

Figure 12 is an example of volume distribution for cells grown with and without $5.0 \mu \mathrm{Ci} / \mathrm{ml} 3 \mathrm{HCT}$. The control culture has a volume distribution compatible with an asynchronous growing population. The distribution is skewed toward the right. Small cells, which predominate, are on the left side and large cells tail off toward the right. The culture labeled for 72 hours has a volume distribution which is displaced to the right and which has a wide dispersicn, in iicating that these cells are larger than the control cells. The increase in cellular volume may be due to cells which are blocked in diploid $G_{2}$ or tetraploid $G_{1}$ fullowed by unbalanced growth or an increase in ploidy level.

Table 3 shows that there is a continuous increase in cellular volume during exposure to the ${ }^{3}$ IIdT. For the control culture, the modal clannel number show's no change with time. The modal channel number of the culture with $5.0 \mathrm{\mu Ci} / \mathrm{ml}{ }^{3} \mathrm{IdTT}$ increases by approximately two times the control at 48 hours of exposure (or day 2). The modal 
$-60-$

Figure 12. Coulter volume distribution of WI-38 cells continuously exposed to high levels of ${ }^{3} \mathrm{HdT}(20.0 \mathrm{Ci} / \mathrm{mM})$. The upper panel represents the untreated cells. The ower panel represents the cells which were labeled wit $15.0 \mu \mathrm{Ci} / \mathrm{ml}$ ${ }^{3}$ HdT for 72 hours. 

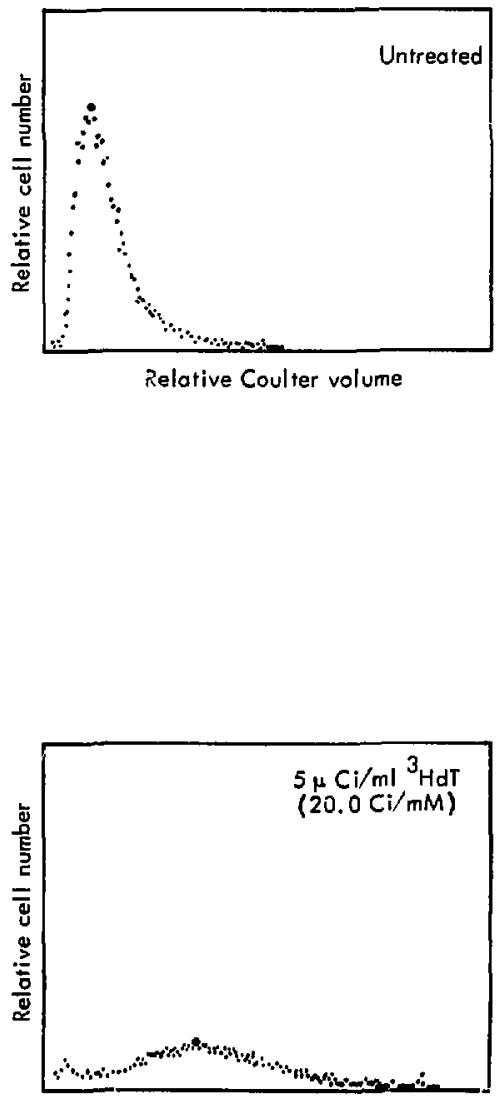

Relative Coulter volume

ligure 12. 
channel number continues to increase with time, and is four and one-half times larger than the control at 96 hours of exposure (or day 4).

In summary, these data show that celiular growth is inlijited by continuous exposure to $1.0 \mu \mathrm{Ci} / \mathrm{ml} \overrightarrow{3}_{11 \mathrm{dT}}$ (S.A. $20.0 \mathrm{Ci} / \Omega \mathrm{M}$ ) or $5.0 \mu \mathrm{Ci} / \mathrm{ml}$

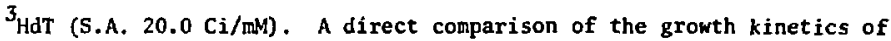
cells exposed to these two levels of ${ }^{3} \mathrm{HdT}$ should not be made, since $1.0 \mu \mathrm{Ci} / \mathrm{ml}{ }^{3} \mathrm{HdT}$ was added 24 hours after seeding the culture (exponential phase), whereas $5.0 \mu \mathrm{Ci} / \mathrm{ml}^{3} \mathrm{HdT}$ lias added at the same time the culture was seeded (lag phase). Nevertheless, data from both experiments are consistent with the interpretation that cell division may proceed during the first 24 hours of labeling. At $4 B$ hours or longer periods of labeling the cell number and $L$ : are constant, which indicates that cell division 15 inhibited, in addition, at 48 hours ${ }^{3}$ HdT exposure the cell volume is approximately twice the control, which suggests that the cells block in diploid $G_{2}$ or tetraploid $G_{1}$ phase. Further exposure to ${ }^{3} \mathrm{HdT}$ results in further volume increases. due to unbalanced growth or an increase in ploidy level. Cytophotometric-autoradiographic experiments, reported in Section II, show that virtually all cells which incorporate $3_{\text {HdT have } 4 C \text { DNA. }}$, which strengthens the hypothesis that inigh levels of ${ }^{3}$ HdT tock cells in diploid $\mathrm{G}_{2}$ or tetraploid $\mathrm{G}_{1}$ phase. 
b. Effect of different methods of slide preparation on labeling index

An increase in the $C V$ of $D K A$ values for old cultures could arise from a high slide hackground. Aging $k I-38$ cultures have increased amounts of "celiular debris". DNA contents reported in Section I were letermined on nuclei of intact whole cells which here fixed, stained and measured while remaining attached to the slides on which they were grown (sce Materials and Methods: $C, 1 b$ ). Utilizing this method of slide preparation, a large proportion of the debris also remained attached to the slides. DNA contents reported in Section 1 I were determined on nuclei devoid of cytoplasm, and fixed to freshly cleaned slides. To prepare these slides, cells were subjected to trypsin (which lyses a good deal of the debris), hypotonic KCl and centrifugation, and were dropped on wet microscope slides (sec Materials and Nethods: $C, 2 b$ ). Selective loss of either dividing or nondividing cells during treat:ient was tested iy measuring the $L 1$ of cells trested according to Section I (method 1) compared to the laheling index of cells treated according to section II (method II). (ultures of various population doubling levels (PDL) werc utilized.

In all the txperiments the labeling index was higher for method II (see table 4). A simple T test revealed that in only one instanc: (experiment 4) was the difference between methods significant. A paired T test (Snedecor and Cochrau, 1967), using a arcsin transformation of the labeling indices in order to stabilize the 


\section{EFFECT DF DIFFERENT METHODS OF SLIDE PREPARATION ON LABELING INDEX}

\begin{tabular}{|c|c|c|c|}
\hline \multirow{2}{*}{ Experiment } & \multirow{2}{*}{ PDC $^{\circ}$} & \multicolumn{2}{|c|}{$L(\%)^{b}$} \\
\cline { 3 - 4 } & 44 & Method $I^{\mathrm{c}}$ & Method $\mathrm{II}^{\mathrm{d}}$ \\
\hline 1 & 46 & 91.8 & 94.8 \\
\hline 2 & 46 & 91.8 & 95.0 \\
\hline 3 & 46 & 87.8 & 91.0 \\
\hline 4 & 59 & 53.5 & 61.3 \\
\hline 5 & 61 & 18.3 & 21.5 \\
\hline
\end{tabular}

0 . Different strains of $W l-38$ cultures were used, therefore a direct comparison of PDL to determine "oge" cannot be made.

b. 400 cells per culture were counied.

c. Cells remained altached to slides on which they wern grown.

d. Cells were trypsinized and devoid of cytoplasm. 
variance, showed that the labeling index of cells treated by metiod II is significantly higher than the labeling index from cells treated by method 1 . This indicated that nondividing cells were selectively lost by the harsh treatment of method $I I$.

'This hypothesis was tested further by measuring the labeling index of cells that resisted release from the plastic by trypsin (experiment 5). The labeling index of cells remaining on the plastic after trypsin treatment ( $4.0 \%$ ) was much lowor tran the labeling index of cclls subjected to method I (18.5\%) or method II (21.5\%). Nondividing cells appear to resist the releasing action of trypsin more than dividing cells. This does not rule out the possibility of further loss of dividing and/or nondividing cells due to cellular lysis during method II.

In conclusion, nonrividing hI- 38 cells are selectively lost when treated by method II. The effect is a small one and can only be shown by involved analysis on experimentally paiced data. However, DNA measurements were mado on on $1 y$ loo cells per culture (based an a pragmatic time limit). This small sample size could introduce a bias, and should be kept in mind in interpretation of the data.

c. DNA cytophotometry of dividing and rondividing Wi-38 cells

(1) Double labeling with ${ }^{3}$ HdT

Experiments lere performed to compare the dispersion of DNA values 
in old and young WI-38 cultures, and in dividing and nondivicing cells. Cells were double labeled with ${ }^{3} \mathrm{HdT}$. Exposure to $0.003 \mu \mathrm{Ci} / \mathrm{ml}$ ${ }^{3}$ HdT for 48 hours labeled the dividing cells but did not affect their growth kinetics (Results: 2, a(1)) and at the end of this period, exposure to $100 \mu \mathrm{Ci} / \mathrm{ml}^{3}{ }_{\mathrm{HdT}}$ for 30 minutes labeled the cells in $\mathrm{S}$ Thase, Cytophotometric measurements were made on fixed, stained nuclei, foljowed by autoradiographic detection of ${ }^{3}$ HdT uptake.

Figure 13 shows histograms of cytophotometric-attoradiographic data from young population doubling level $2:$ (PDL 24) and old (PDL 55 and PDL 62) cultures. Each histogran is divided into lightly labeled (cycling $\mathrm{G}_{1}$ or $\mathrm{G}_{2}$ phase) nuclei, heavily labeled (cycling $\mathrm{S}$; hase) nuclei and unlabeled (noncycling) nuclei.

The youngest culture (PDL 24) has a bimodal distribution typical of an asynchronous proliferating population. Therc are no unlabeled nuclei. Lightly labeled nuclei are distributed in well defined peaks at $2 C$ and $4 C$, and are, presumably, in diploid $G_{1}$ and $G_{2}$ phase. Thirty percent of the nuclei are in $G_{1}$ phase: $22 \%$ of the nuclei are in $G_{2}$ phase. Heavily labeled (S phase) nuclei have DN.A values intermediate between $2 \mathrm{C}$ and $4 \mathrm{C}$, and comprise $47 \%$ of the nuclei. There is one nucleus with a hypertiploid DNA content, and it has a labeling pattern and DNA content consistent with being in $S$ phase.

An older culture (PDL 55) has polyploid nuclei with $8 \mathrm{C}$ and $16 \mathrm{C}$ DNA. Unlabeled nuclei have well demarcated peaks of $2 \mathrm{C}, 4 \mathrm{C}$ and $8 \mathrm{C}$ DNA contents. The $2 \mathrm{C}$ peak contains $40 \%$ of the unlabeled nuclei and the $4 \mathrm{C}$ 
Figure 13. Feulgen DNA stain content of aging lid-38 cultures double labeled hith $j_{1 l d T}$. The histograms are arranged according to increasing age ( $\mathrm{PDL}$ ). The stiunled bars represent cells which incorporated 0.003 wCi/fil ${ }^{3}$ Hd $(5 . \lambda$. $\left.2.0 \mathrm{Ci} / \mathrm{m}^{4}\right)$ at $i 8$ hours of exposure and which were lightly labe?ed in autoradiograns. The hatched bars represent cells which incorporated $100.0 \mathrm{\mu Ci} / \mathrm{ml}{ }^{3}$ lldT (S.A. $2.0 \mathrm{Ci} / \mathrm{mN}$ ) at a 30 minute pulse wind which vere heavily labeled in autoradiograms. The clear bars represent the unlabeled cells. DAA content is given in arbitrary CrDAC units (ACU) of $C$ where $2 C$ is the diploid DNA content, operationally defined in terms of the mean of the first peak. Incluted in the data of the rOL 6? culture are the Dhid values of the unlabeled cells fron a sister culture labeled for 48 hours $w i$ th $5 \mathrm{\mu Ci} / \mathrm{ml}{ }^{3} \mathrm{HdT}$ (S.A. $20.0 \mathrm{Ci} / \mathrm{mN}$ ) (see figure 14, bottom). 


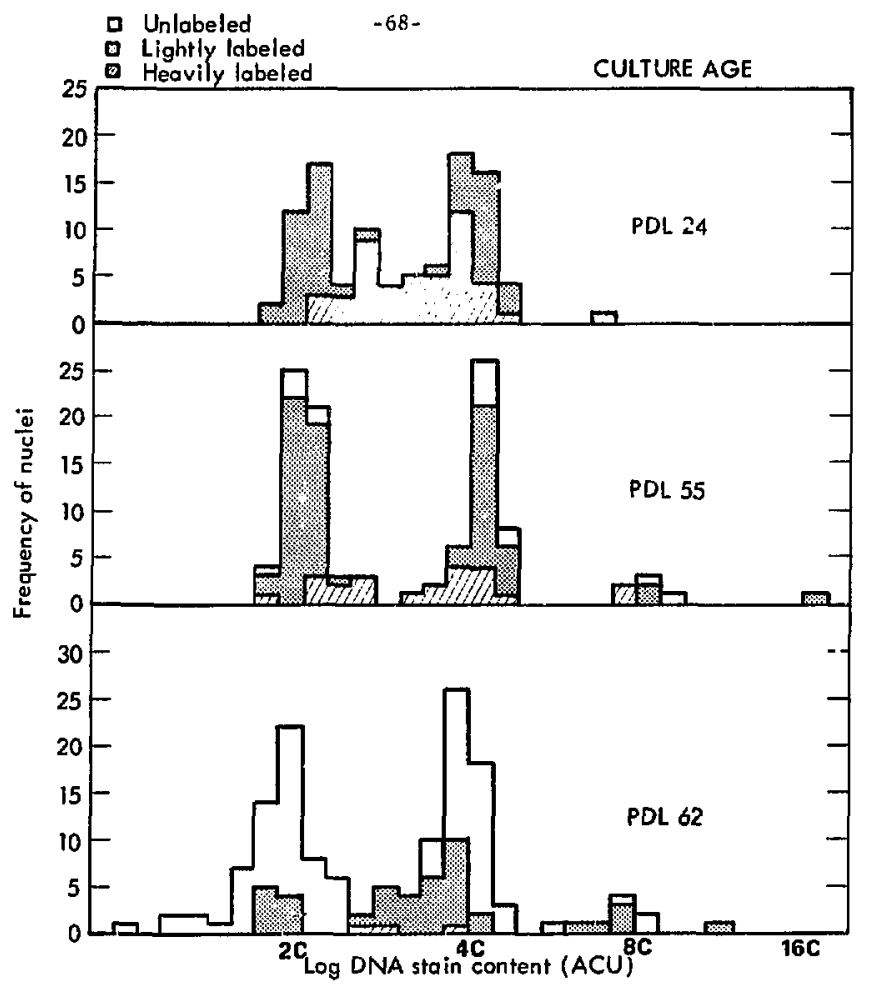

Figure 13. 
peak contains $47^{\circ}$. Once again, the heavily labeled nuclei (S phase) arc intermediate in DNA value, and the lightly labeled nuclei define sharp peaks at the $2 C$ and $4 C$ levels. There are fewer heavily labeled (S phase) nuclei than in the young culture: $25 \%$ of the labeled nuclei arc in $S$ phase here, whereas $47 \%$ were in $S$ phase in the younger culture. The $2 \mathrm{C}$ and $4 \mathrm{C}$ peaks contain, respectively, $45 \%$ and $26 \%$ of the labeled nuciei. There are two nuclei with hyperdiploid DNA contents and they are presumed to be in $S$ phase.

Interpretation of the histogram of the oldest culture (PDI, 62) is not as definitive as the other cultures. There are polyploid labeled and unlabeled nuclei with 8C DNA. Heavily labeled nuclei have intermediate DNA values. Orily $7 \%$ of the labeled nuclei have a labeling pattern consistent with being in the $S$ phase. Lightly labcled nuclei have $2 \mathrm{C}, 4 \mathrm{C}, 8 \mathrm{C}$ and intermediate $\mathrm{DNA}$ values. Only $20^{\circ}$ of the labeled nuclei are in the $2 \mathrm{C}$ peak, and $59^{\circ}$ have either $4 \mathrm{C}$ or intermediate DNA values. The lightly labeled nuclei with internediate DNA values cause a left skew to the aC peak. These nuclei may be aneuploid, or they may be lightly labeled s phase nuclei (i.e., cells in $\mathrm{S}$ phase which incorporated low levels of ${ }^{3} \mathrm{hdT}$ ). The few 1 ightly labeled SC nuclei appear to be skewed to the left. Unlaheled nuclis have $2 \mathrm{C}, 4 \mathrm{C}, 8 \mathrm{C}$ and internediate DNA values. The $2 \mathrm{C}$ peak contuins $53^{\circ}$ of the unlabeled nuclei. Nuclei with hypodiplojd DNA contents cause the unlabeled $2 \mathrm{C}$ peak to skew to the left. The unlabeled $4 \mathrm{C}$ and $8 \mathrm{C}$ peaks contin, respectively, $44 \%$ and $3 \%$ of the unlabeled nuclei. 
Quantitative data analysis is shown in table 5. S phase nuclei were subtracted from the DNA histograms in figure 13 to yield $2 \mathrm{C}$ and $4 \mathrm{C}$ peaks of DNA values. Then the $\mathrm{CV}$ of the $2 \mathrm{C}$ and $4 \mathrm{C}$ peaks, and the ratio of $4 \mathrm{C}$ to $2 \mathrm{C}$ DNA values were calculated.

In the PDL 24 culture, the peaks of labeled $2 \mathrm{C}$ and $4 \mathrm{C}$ nuclei have a small $\mathrm{CV}(6.9 \%$ and $6.6 \%$, respectively), which indicates that there is little dispersion in the DNA values. In addition, the ratio of $4 \mathrm{C}$ to $2 C$ mean DNA values is approximately two. This irdicates that the specimen, the Feulgen stain, and the cytorhotometric measurements behaved extremely well.

In the PDL 55 culture, the $\mathrm{CV}$ is similar for labeled and unlabeled nuclei, in both the $2 \mathrm{C}$ and $4 \mathrm{C}$ peaks of DNA values. Like the young culture, the $\mathrm{CV}$ is snall (approximately $6.0 \%$ ), and the ratio of $4 \mathrm{C}$ to 2C mean DNA values is approximately two.

The POL 62 culture has a labeled $2 \mathrm{C} \mathrm{CV}$ which is similar to the younger cultures. In this old culture, however, the unlabeled $2 \mathrm{C} \mathrm{CV}$ (17.4\%) is much larger than the labeled $2 \mathrm{C} \mathrm{CV}(5.5 \%)$. The $\mathrm{CV}$ of the unlabeled $4 C$ peak (11.0\%) is similar to the $C V$ of the labeled $4 C$ peak (12.6\%). With the exception of the labeled 2C nuclei, the PDL 62 culture has a $\mathrm{CV}$ of peak DNA values which is more than two fold larger than the PDL 55 or PDL 24 cultures. The significance of the increased $\mathrm{CV}$ in the oldest culture is uncertain because the peaks are skewed. Possible explanations for the skewed data are given in the Discussion. Deviation from the expected 2 to 1 ratio of $4 C$ to $2 C$ mean DNA values 
COF.rFiCIENT OF VARIATION OF DNA VALUES AND RATIO OF 4C TO 2C DNA VALUES WITH AGE

\begin{tabular}{|c|c|c|c|c|c|c|}
\hline \multirow{3}{*}{$\begin{array}{c}\text { Culture } \\
\text { age }\end{array}$} & \multicolumn{4}{|c|}{ Coefficient of variation ( $\%)$} & \multirow{2}{*}{\multicolumn{2}{|c|}{$\begin{array}{l}\text { Ratio of mean DNA } \\
\text { values of } 4 C \text { to } 2 C \text { peaks }\end{array}$}} \\
\hline & \multicolumn{2}{|c|}{$2 C$ peak } & \multicolumn{2}{|c|}{$4 C$ peak } & & \\
\hline & Labeled & Unlabeled & Labeled & Unlabeled & Labeled & Unlabeled \\
\hline PDL 24 & 6.9 & $=$ & 6.6 & - & 1.97 & - \\
\hline PDL 55 & 5.6 & 6.2 & 5.7 & 5.2 & 2.08 & 2.13 \\
\hline PDL 62 & 5.5 & 17.4 & 12.6 & 11.0 & 1.85 & 2.30 \\
\hline
\end{tabular}

inble 5 . 
is probably due to the skewed data. The labeled $4 \mathrm{C}$ peak is more skewed than the labeled $2 \mathrm{C}$ peak, and the ratio of their mean DNA values is significantly less than two. The opposite is true for unlabeied nuclei. The unlabeled $4 \mathrm{C}$ peak is less skewed than the unlabeled $2 \mathrm{C}$ peak, and the ratio of the $4 \mathrm{C}$ to $2 \mathrm{C}$ mean DNA values is significantly greater than two.

Generally speaking, the oldest WI-38 culture has an increased $\mathrm{CV}$ of $2 C$ and $4 C$ DNA values. In addition, for cultures of al: ages, uniabeled nuclei do not have a greater CV than labeled nuclei. The combination of double label ${ }^{3} \mathrm{HdT}$ autoradiography and DNA cytophotometry proved to be an expedient approach to identify cells in $\mathrm{S}$, and thereby define the boundaries of $2 \mathrm{C}$ and $4 \mathrm{C}$ peaks. However, the data from the oldest culture was more complex than anticipated, and is difficult to interpret.

(2) Labeling with high levels of ${ }^{3} \mathrm{HdT}$

Cytophotometric-autoradiographic experiments were performed on fixed, stained nuclei from WI-38 cultures continuously labeled with $5.0 \mu \mathrm{Ci} / \mathrm{ml}^{3} \mathrm{HdT}(\mathrm{S} . \mathrm{A} .20 .0 \mathrm{Ci} / \mathrm{mM}$ ). Ce11s grown in this concentration of ${ }^{3}$ HdT cease to divide and increase in volume (Results: $2, a(2)$ ). The DNA content of the cells blocked by high levels of ${ }^{3} \mathrm{HdT}$ was determined, and the results are shown in figure 14.

Figure 14 shows histograms of the data from young (PDL 24) and old (PDL 62) cultures which are sister cultures to those utilized in the double labeling experiment. Nuclei which are labeled ceased cycling 
Figure 14. Feulgen DNA stain content of aging HI-38 cultures exposed to high levels of ${ }^{3} \mathrm{HdT}(20.0 \mathrm{Ci} / \mathrm{mM})$. The histograms are arranged according to increasing age (PDL). The solid bars represent cells which incorporated $5 \mu \mathrm{Ci} / \mathrm{ml}{ }^{3} \mathrm{HdT}$ during a 48 hour exposure. The clear bars represent the unlabeled cells. DNA content is given in arbitrary CYDAC units (ACU) of $C$ where $2 C$ is the diploid DNA content, operationally defined in terms of the mean of the first peak. 


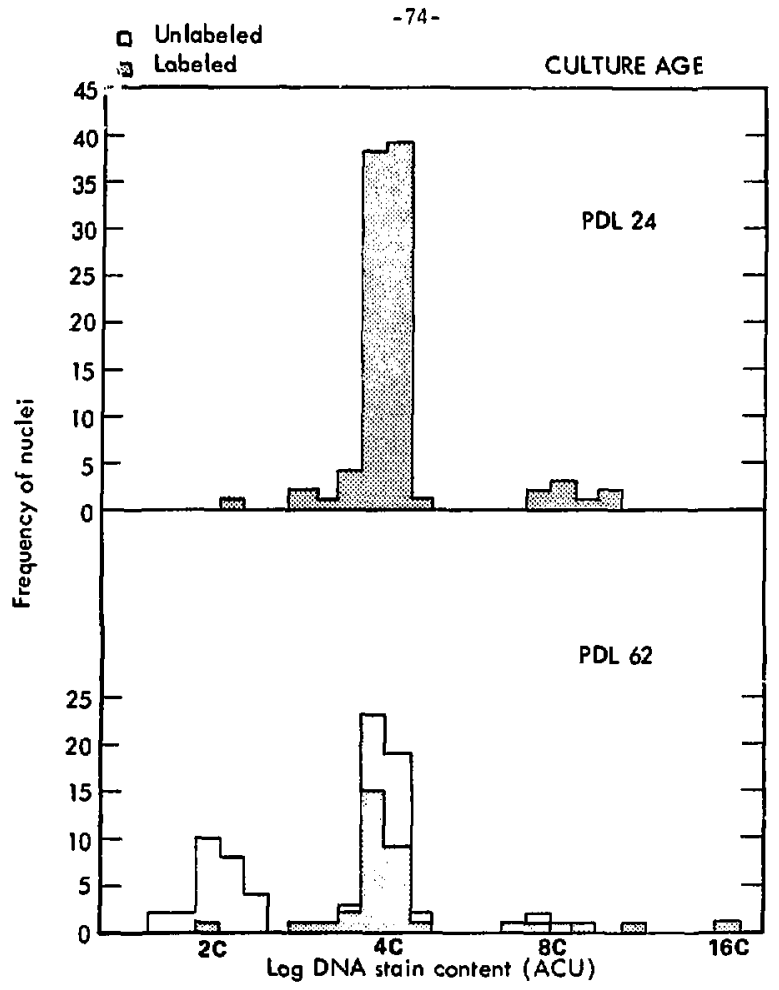

Fígure 14. 
after the addition of $3_{\text {JdT }}$, and are termed blocked djviding cells. Unlabeled nuclei ceased cycling lefore the addition of ${ }^{3} H \mathrm{dT}$, and are terined nondividing cells.

In the PDL 24 culture, therc is a major peak of DNA values $\left(20^{\circ}\right.$ of the nuclei) at the $\triangle C$ level. One percent of the nuclei have $2 \mathrm{C}$ is values and $9 \%$ of the nuclei have $8 \mathrm{C}$ [MA values. All the nuclei are labeled; there are no nondividing cells.

The labeled nuclei of the PDL 62 culture have a distribution sinilar to the PDL 24 culture. There is a major peak of aNit values ( $83^{\circ}$ of of the labeled nuclei) at the $4 C$ level. Three percent of the labeled nuclei have $2 \mathrm{C}$ LNit values and $14^{\circ}$. have botween $18 \mathrm{C}$ and loc lin values. The majority (54\%) of the unlabeled nuclei fave $2 \mathrm{C}$ (NA ralues and tis have 8C DNA values.

In summary, lil-38 cells which label during 48 licurs expusure to Jigh levels of 3 lldT have, almost exclusively, tC IWh. These a: blocked dividing cells may be diploids in $G_{2}$ phase or tetraploids in $G_{1}$ phase.

\section{B. Premature Chronosome Condensation-Autoradiogr.uplic Studies \\ 1. Section 111}

Combined TNA cytophotometry and autoradiograply, reforted in Sections 1 and 11 , demonstrated that the majorizy of nondiriding hi-st cells have $2 \mathrm{C}$ DNA contents, consistent with the incerpretation that they are diploid cells arrested in $t_{l}$. Increasing culturc age was 
associated with iucreasing numbers of nondividing cells with 4C DNA contents as well as with proliferating and nonproliferating polyploid cells. It ms uncertain whether the nondividing $4 \mathrm{C}$ cells were arrested as diploid $G_{2}$ or as tetrap.oid $G_{1}$ cells. To continue the investigation of aging nondividing cells premature chromosome condinsation, (PCC) was utilized (1) to determine whether nondividing cells could condense their chromatin; (2) to determine the stage of the coll cycle in which these cells are arrested; and (3) to determine the ploidy level of the nondividing cells.

The prenature chromosome condensation-autoradiograph technique was performed as follows. Middle-aged and old cultures of WI-38 cells were laboled for 48 hours with $0.1 \mu \mathrm{Ci} / \mathrm{ml}{ }^{3} \mathrm{HdT}$ (S.A. $2.0 \mathrm{Ci} / \mathrm{nN}$ ). HI-3B cells were fused with mitotic cells, which induced interphase chromatin to condense into prematurely condensed chromosomes. The chronosomes were exanined to deteraine cycle stage and ploidy level; cells were classified as either $G_{1}$ if thoy contained single chromatids or $\mathrm{C}_{2}$ if thoy contained double chromatids, and, as either diploid if they contained is chromosomes of tetraploid if they contained 92 chromosones. Autoradiographic detection of $3_{\text {lldT }}$ uptake further classified the cells as dividing (labeled) or nondividing (unlabeled).

a. Fusion of WI-38 cells with mitotic CHO cells

Mitotic clo cells were chosen to induce PCC because the diploid chromosome number (21) is easy to distingutsh from the diplotd chromosone nuber of $W T-38$ cells (46). Mitotic CHo cells were collected by a shake - synchrony method (Materials and Methods: 
$1,1 a(2))$. At appropriate time intervals, Cllo cells blocked in mitosis by Colcenid, were collected from the monolayer by gentle shaking. After 45 minutes in Colcemid (sample B) loose cells and debris come off the monolayer along with mitotic cells. The mitotic index (MI) is 41: (table 6). The MI rises to $78^{\circ}$ one hour later (sample $C$ ). Samples $D, E$ und $F$, collected over the next few hours, have a MI from 91 to $92 \%$. Each sample was monitored for Coulter volume distribution. The modal channei li.mber is approximately two times greater for mitotic cells than for cells without Colcemid (figure 15). Pooled CHO cells from samples D, E and F were suspended, according to the fusion procedure (Materials and Methods: D, Ib(2)), with WI-35 cells, but did not induce PCC. A likely explanation is that CHO cells and LI-38 cells do not fusc readily.

\section{Fusion of HI-38 with mitotic Hela cells}

Hela cells are known to fuse readi!y with $k I-38$ cells and, therefore, were chosen to induce PCC. The modal chromosome number of Hela cells is sufficiently large (approximately 100) to distinguish then from lil-38 cells. To further aid ideltification the Hela cells

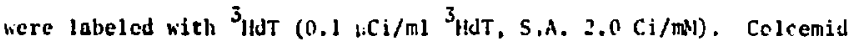
wals added to the HeLa monolayer to ploch mitosis and the mitetic cells were collected by Jecinting (staterials and Methods: $\mathrm{D}, 1 \mathrm{a}(5))$. The N!] was 99.9" and 99.7? of the nitoses labeled. The modad rolun of of the

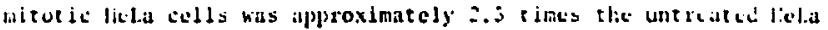
colls (figure fo). This is larger than thice the volume of a cell in 
MITOTIC INDEX OF CHO CELLS COLLECTED IN COLCEMID $(0.06 \mathrm{mg} / \mathrm{m}$ I)

\begin{tabular}{|c|c|c|}
\hline Sample & Time in Colcemid (min) & Mitotic Index (\%) \\
\hline A & 0 & - \\
\hline$B$ & 45 & 41 \\
\hline C & 105 & 78 \\
\hline$D$ & 165 & 91 \\
\hline E & 225 & 92 \\
\hline F & 390 & 91 \\
\hline
\end{tabular}

Table 6 . 
Figure 15. Coulter volume distribution of mitotic CHO cells collected in Colcenid by the shake-synchrony method. The upper panel represents the untreated cells. The lower panel represents the cells treated with $0.06 \mathrm{\mu g} / \mathrm{ml}$ Colcemid; the cells were pooled from samples D, E and F (see table b), and had a MI of approximately $92^{\circ}$. 
$-80-$

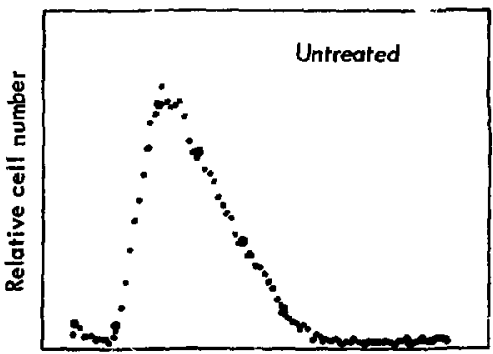

Relotive Coulter volume

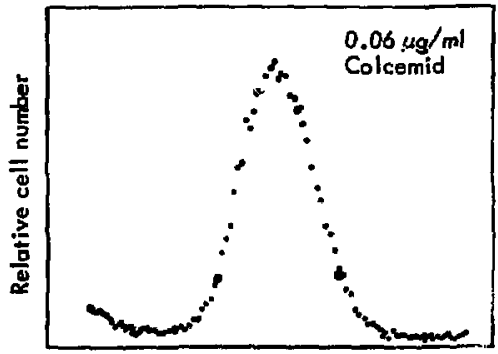

Relative Coulter volume

Figure 15. 
Figure 16. Coulter volume distribution of labeled mitotic Hela cells collected in Colcemid. The upper panel represents the untreated cells. The lower panel represents the cells exposed to $0.1 \mathrm{\mu Ci} / \mathrm{ml}^{3} \mathrm{HdT}$ (S.A. $2.0 \mathrm{Ci} / \mathrm{mM}$ ) for 26 hours. For the final 26 hours of labelins $0.25 \mu g_{i}$ ml Colcemid was added. The mitotic index of this culture was $99.9 \%$ and $99.7 \%$ of the mitoses were labeled. 
$-82-$

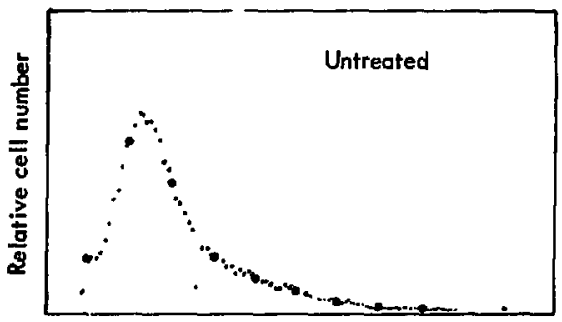

Relative Coulter volume

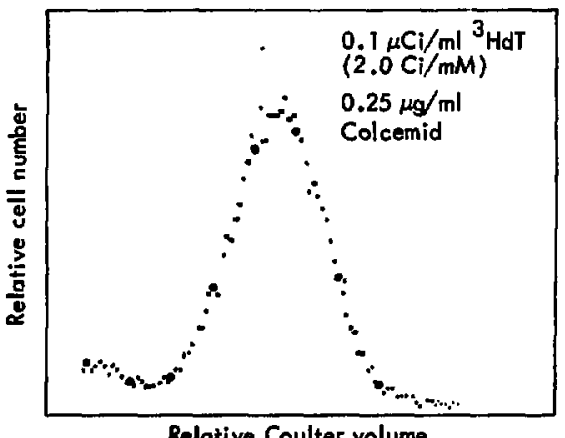

Figure 16. 
$i_{1}$. A likely explanation is that colcemid blocked cells still synthesize protein, which results in increased volume.

Two cultures, a middle-aged culture containing $34 \%$ nondividing cells (culture A) and an ald culture with $76 \%$ nondividing cells (culture B), were fused to mitotic lleLa cells to induce PCC. The frequency of PCC (WI-38) per total cells (WI-38, HeLa, heterokaryons) was $1.3 \%$ for miture $A$ and $1.0^{\circ}$ for culture $B$. The difference is not significant $(p=0.37)$.

Typical chromosome cundensation patterns observed are shown in figures 17-20. Since the chromosomes of the mitotic HiLa cells were highly contracted and were always labeled, they were easy to distinguish from the less condensed interphase $\mathrm{HI}-38$ chromosomes. Out of $178 \mathrm{G}_{1}$ diploid PCC configurations (figure 17) examined from i:'e two cultures, 98 were unlabeled (table 7), In $19 \mathrm{PCC}$ celis, the WI-38 chromosomes exhibited the $\mathrm{G}_{2}$ diploid pattern (figure 18 ). All of these cells nere labeled (figure 18, inset). The WI-38 G tetraploid PCC configuration shown in figure 19 was observed in 15 cells of which 10 were unlabeled. Thjs typical polyploid cell has approxinately 92 unpaired chromatids. Such a configuration is distinc from that obscrved in figure 20, where the 92 chromatids shou apparent homologous pajring at the centromere regions and exhibit wide separation along the arms. This anomalous pairing was observed in three cells, all unlabeled. Additionally, two mlabcled cells with approximately a diploid chromosome number also demonstrated this unexpected pairing. Unfortunately the cluromatids were highly clumped 
$-84-$

Figure 17. Autoradiograph of an unlabeled WI-38 $\mathrm{G}_{1}$ diploid PCC and labeled mitotic Hela chromosomes. 


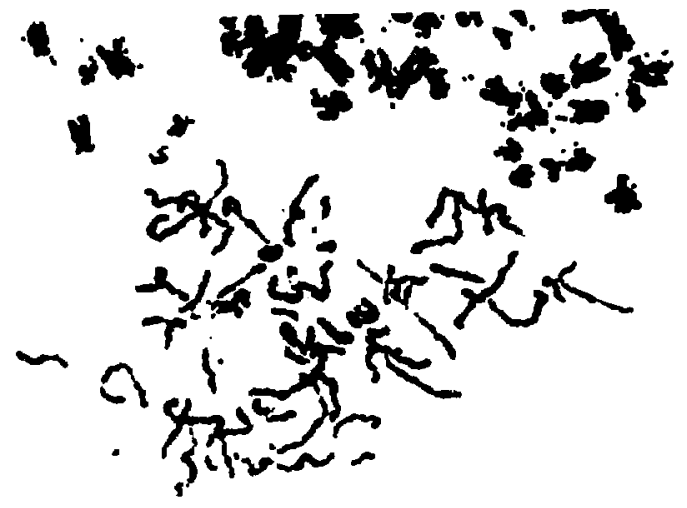


$-86=$

Figure 18. WI-38 $\mathrm{G}_{2}$ diploid PCC and mitotic Kets ehromosomes. Inset the sane cell after atoradiography. 


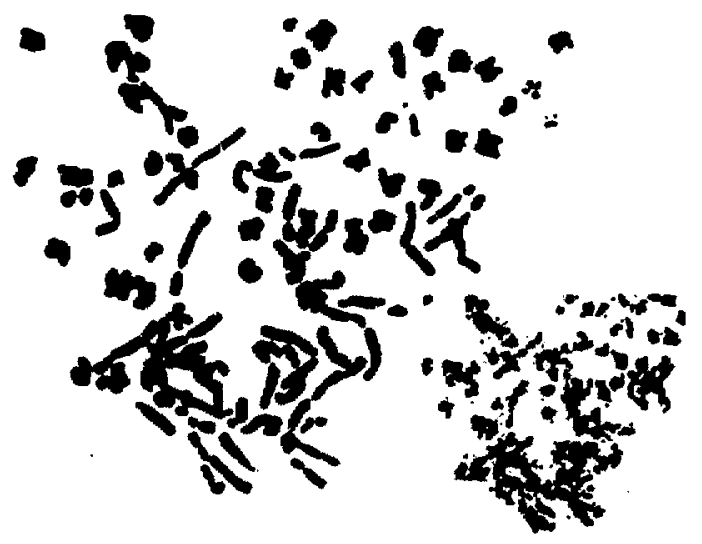

Figur 18.

H. Yanishevsky 
Figure 19. WI-38 $\mathrm{G}_{1}$ tetraplofd PCC with approximately 92 single chronetids and mitotic HeLa chromosomes. 


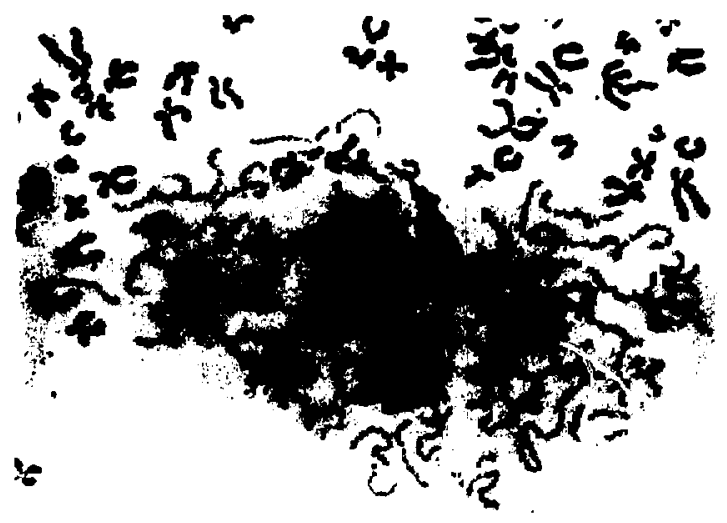

Figure 19.

R. Yanishevsky 
$-90$

Figure 20. Autoradiograph of an unlabeled WI-38 PCC containing approximately 92 paired chromatids and labeled mitotic HeLa chromosones. 


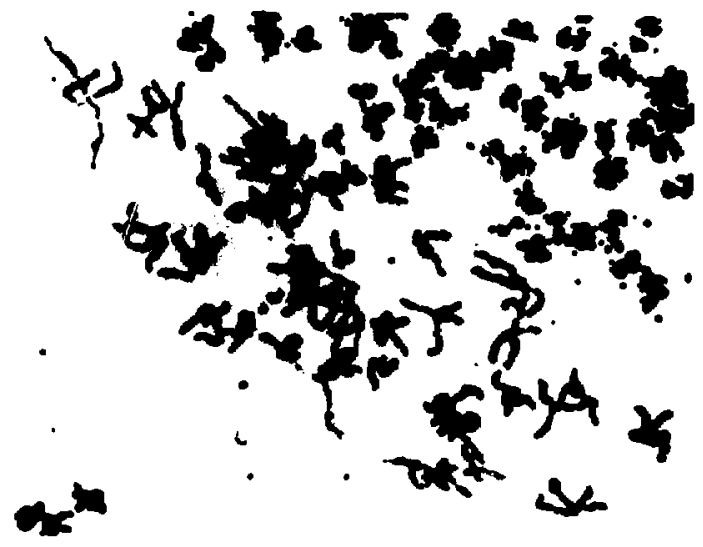

Fieure 20.

R. Yanishevsky 
PERCENTAGE OF NONDIVIDING CE'LS IN PARENT CULIURES, FREQUENCY OF PCC, AND CELL CYCLE DISTRIBUTION OF UNLABELED CELLS WITH PCC.

Numbers in parentheses refer to actual cell counts.

\begin{tabular}{|lcc|c|cc|c|}
\hline & $\begin{array}{c}\text { Nondividing } \\
\text { cells in porrent } \\
\text { cultures }(\%)\end{array}$ & $\begin{array}{c}\text { Cells with } \\
\text { PCC }\end{array}$ & \multicolumn{4}{|c|}{ Unlabeled ceils with PCC (\%) } \\
\cline { 5 - 8 } & Totol & $G_{1}$ & $G_{2}$ & $G_{1}$ \\
\hline Culture A & $34^{0}(175 / 519)$ & $1.3^{b}(20 / 1549)$ & $32^{C}(33 / 104)$ & $37^{d}(30 / 81)$ & $0(0 / 16)$ & $43(3 / 7)$ \\
Culture B & $76(996 / 1308) 1.0$ & $(5 / 504)$ & $69(75 / 108)$ & $70(68 / 97)$ & $0(0 / 3)$ & $88(7 / 8)$ \\
\hline
\end{tabular}

a. Expressed as $100 \times$ unlabeled cells/total cells.

b. Expressed as $100 \times$ WI -38 cells with PCC/heterokoryons, WI -38 and thela cells.

c. Expressed as $100 \times$ (unlabeled $G_{1}$ and $G_{2}$ cells with $\left.P C C\right) /\left(G_{1}\right.$ and $G_{2}$ celis with $P C C$ ).

d. Expressed as $100 \times$ unlabeled $G_{1}$ diploids/ $G$, diploids,

$100 \times$ unlabeled $G_{2}$ diploids $/ G_{2}$ diploids,

or $100 \times$ unlabeled $G_{1}$ tetroploids/ $G_{1}$ tetroploid:

Table $?$. 
and thus we could only roughly est inate them. These five cells were not included in the analysis of the quantitative data but will be considered in the niscussion.

is shown in table 7, a total of 104 PCC configurations was scored in culture $A$ and 1.18 in culture $B$. Thirty-two percent of these in culture $A$ and $69^{\circ}$, in culture $B$ were unlabeled. This is similar to $34^{\circ}$ and $76^{\circ}$ nondividing cells observed in parent cultures $A$ and $B$, respectively. In the calculation of the percent of cells with PCC the $S$ phase celis were excluded, whercas in the calculation of the percent of nondividing cells in the parent cultures they were included. The effect of labeled $S$ phase PCC configurations would be to decrease the percentage of unlabeled cells with PCC observed. If the data in table 7 is expressed as the ratio of culture $B$ to culture $A$, the aging effect on cells in $G_{1}$ and $G_{2}$ is shown independently of the $S$ phase cells. This ratio is equal to 2.2 for both the percent of unlabeled ceIls with PCC and the percent of nondividing cells in the parent cultures. This approximate two-fold increase in the frequency of nondividing cells correlates with the increase in unlabeled $G_{1}$ diploid cells with PCC. The frequelcy of all $G_{1}$ cells with PCC (labeled and unlabeled) increases significantly $(p=0.03)$ from culture $A$ to culture $B$, while the frequency of labcled $C_{2}$ cells with PCC decreases significantly $(\mathrm{N}=0.002)$. The number of unlabeled tetraploid cells observed is small and there is no significant increase in this class with culture age $(p=0.1 \mathrm{~J})$. 
The expected proportion of $G_{1}$ and $G_{2}$ cells showing PCC in culture A (348 nonaividing cells) was estimated using cytophotometric-autoradiographic data presented in Section I of a culture (here called culture C) containing 32\% nondividing cells. The DNA histogram of the dividing population of sulture $C$ was partitioned into $G_{1}(2 C)$ and $G_{2}(4 C)$ cells by subtracting out the cells with intermediate GNA contents (an approximation of the cells in $S$ ). In the nondividing population the DNA histogram consisted only of cells with 2C DNA contents. This information gave the percentages of dividing and nondividing cells with $2 C$ and $4 C$ DNA in a culture of this age. To calculate the expected partitioning of cells with PCC in culture $A$, the percentage of vells in the different phases was multiplied by the total number of observed labeled or unlabeled cells with PCC. The observed and expected values for culture A are given in table 8. There is no significant difference within the various classes, indicating that, with the statistical limitations of the data, PCC is induced with equal efficiency in djviding and nondividing cells as well as in $G_{1}$ and $G_{2}$ cells. A comparable analysis with culture $B$ was not possible with the data at hand. In interpretation of this data it should be kept ir mind that the sample size was small, and that the PCC and cytophotometric experiments utilized different methods of slide preparations, which may bias the data. In conclusion, PCC of middle-aged and old WI-38 cultures revealed (1) that nondividing celis condense their chromatin as readily as 
NUMBER OF OBSERVED AND EXPECTED WI-38 CELLS WITH PCC IN CULTURE A

The labeled and unlabeled cells are categorized as either "diploid",

(2C) or (4C), or "totraploid" (4C).

Total No. "Diploid" cells

"Tetraploid" cells cells $G_{i}(2 C) \quad G_{2}(4 C) \quad G_{1}(4 C)$

Labeled cells with PCC:

Observed

Expected ${ }^{a}$

Unlabeled cells with PCC:

Observed

Expected

$\begin{array}{ll}71 & 51 \\ - & 50\end{array}$

$33 \quad 30$

- 33

a. Colculated from cytophotometric autoradiographic data of Section I.

b. DNA cytophotometry cannot distinguish between these two classes because their DNA contents ore the same.

Table 8. 
dividing cells; (2) that for the middle-aged culture the efficiency of PCC induction is independent of phase in the cell cycle; (3) that 96\% of the nondividing cells, diploid or tetraploid, induced into PCC have single chromatids and are therefore blocked in the $G_{1}$ phase; (4) that the remaining $4 \%$ of the nondividing cells have anomalous centromeric pairing; (5) that typical $I_{2}$ configurations (double chromatids) were observed only among nondividing cells.

These data further suggest that nondividing cells with $4 \mathrm{C}$ DNA (see DNA histograms of figures 1 and 15) are arrested in tetraploid $G_{1}$ phase, rather than in diploid $G_{2}$ phase. 


\section{DISCUSSION}

As human diploid WI- 38 cultures age, there is a progressive increase in the nondividing fraction of the population. Biophysical and cytological techniques were employed to identify the cycle phase of the nondividing celis. These experiments revealed that most nondividing cells were diploid, and that nondividing cells, diploid or tetraploid, predominated in the $\mathrm{r}_{1}$ phase of the cell cycle.

Additional key findings were that older cultures had an increased frequency of proliferating and nomproliferating polyploid cells, that $\mathrm{C}_{1}$ and $\mathrm{G}_{2}$ cells $\mathrm{jn}$ older cultures had a wider dispersion of DNA values and that some nondividing cells in aging cultures had atypical shromosome configurations. These data are discussed in Sections $I$ and II (Cytophotometric-Autoradiographic Studies) and Section III (Premature Chromosome Condensation-Autoradiographic Studies). The following is a discussion on the limited proliferative capacity of cells in vivo and a brief overview of some current aging theories.

\section{A. Cytophotometric-Autoradiographic Studies \\ 1. Section I}

3. DNA distrihution of dividing and nondividing W1-38 cells

The cycle phase wherein aging nondividing cells kere blocked was initially identified by correlation of DNA stain content and proliferative status for single cells of 1 abeled $\left(0.1 \mu \mathrm{Ci} / \mathrm{ml}{ }^{3} \mathrm{HdT}\right.$, 
S.A. $2.0 \mathrm{Ci} / \mathrm{mM}$, for 48 hớurs) WI-38 cultures, Histograms of figure 1 showed progressive age related changes in DNA content of dividing and nondividing cells.

Young cultures ( $7 \%$ and $32 \%$ unlabeled cells) had a DNA distribution typical of an asynchronous uniploid population. Most of the cells were proliferating. As expected, since each $G_{2}$ cell becomes two $G_{1}$ cells at the point of division, $2 \mathrm{C}$ (diploid $\mathrm{G}_{1}$ ) cells predominate over $4 C$ (diploid $G_{2}$ ) cells. Cells with intermediate DNA values were presumed to be $S$ phase. The few nondividing cells had $2 C$ DNA and were in diploid $G_{1}$ phase.

01 der cultures ( $38{ }^{\circ}$ through $70 \%$ unlabeled cells) had a DNA distribution which indicated deviant kinetic behavior. In contrast to the younger cultures, there were more proliferating $4 C$ cells than proliferating 2C cells. Few proliferating cells were in s phase. In adition, there were proliferating and nonproliferating $8 \mathrm{C}$ cells. Nondividing cells predominantly had 2C DNA contents and, occasionally, had 4C DNh contents.

The re-triction of the majority of the unlabeled cells to the $2 \mathrm{C}$ DNA content is consistent with the interpretation that most WI-38 cells are in the diploid $G_{1}$ phase when they cease cycling. In older cultures, che appearance of unlabeled $4 \mathrm{C}$ cells can be interpreted in the same way provided that these $4 \mathrm{C}$ cells are actually stopping in a tetraploid $\mathrm{G}_{1}$. The simultaneous appoarance of labeled $8 \mathrm{C}$ cells supports the tetraploid interpretation for at least some of these 
cells. Alternatively, the results of Macieira-Coelho et al. (1966), show that aging WI-38 cultures contain cells with very long $G_{2}$ periods; hence unlabeled $4 C$ cells could be diploids arrested in or slowly traversing $G_{2}$. Further experiments were designed to identify nondividing diploid $G_{2}$ and tetraploid $G_{1}$ cells by the technique of PCC (Section III).

An interesting age-correlated observation is the progressive increase in dispersion of DNA stain content in the $2 \mathrm{C}$ and $4 \mathrm{C}$ peaks, especially for nondividing cells. Several interpretations of this age-associated effect have been considered: (1) aging cells may be increasingly arrested in $S$ phase: (2) changes in chromatin organization are known to alter the stoichionetry of the staining reaction (Garcia, 1969, 1970); (3) increased "debris" associated with aging cultures may lead to errors in the cytophotometry; (4) aneuploid DNA content may increase in noncycling older cells.

With respect to the first interpretation, to my knowledge, there are no documented reports that cells cease to cycle in $S$ phase (unless they are chemically blocked). In fact, a number of previous studies (e.g., see reviews by Prescott, 1975; Baserga, 1965, 1968; and Epifanova and Terskikh, 1969) have led to the basic tenet of cell cycle control theories that cells cease to cycle in either $G_{1}$ phase or $\mathrm{G}_{2}$ phase. Furthermore, if cells arrested in $S$ phase, the DNA data would be skewed; this did not occur. Although we cannot rule out noncycling $S$ phase cells, the weight of evidence makes it improbable. 
Alternatively, it is possible that the cells are cycling in $S$ phase, even though they are unlabeled. For instance, cells could synthesize DNA at a rate too low to be detected by the autoradiographic methods used and would be misscored as unlabeled cells. Petes et al. (1974) used DNA fibre autoradiography to show a 25: reduction in tise average rate of DNA chain elongation in senescent human diploid cells. This infers that aging cells have a decreased rate of DNA replication. Other experiments, however, showed that for middle-aged cultures the LI did not increas! with increased ${ }^{3}$ HdT concentration or with increased exposure to autoradiographic emulsion (Cristofalo and Sharf, 1973; Cristofalo, 1975). These experiments indicate that, within statistical 1 imtts, cells which incorporate ${ }^{3}$ HdT will be detected by the autoradiographic methods used. Further experimentation is required for very old cultures.

The second interpretation of the age-associated increase in dispersion of DNA values is that DNA stains nonstoichiometrically in older cells. Nonstoichiometric staining has been traced to small nuclei and highly compacted DNA (e.g., Garcia, 1966; Mayall, 1969). WI-38 cells have very large nuclei and such compaction effects are not to be expected. In fact, cell size (Cristofalo and Kritchersky, 1969) increases with age; although no systematic quantftative studies have been performed, we have observed that nuclear size also increases with age. Furthermore, the stoichiometry appears well behaved on the basis of both the doubling of $2 \mathrm{C}$ to $4 \mathrm{C}$ to $8 \mathrm{C}$ peaks and the lack of shift of 
DNA modes when labeled and unlabeled cells are compared. Therefore, the possibility of nonstoichemtric staining seems unlikely.

The third interpretation is that "debis" leads to errors in eytophotometric measurements. Large amounts of debris occur in old cultures, probably from the lysis of dead cells. Debris causes a nonuni form slide background. This could cause inaccurate DNA measurements. Each DNA mensurement requires two background readings: (1) the integrated optical density (IOD) is measured for a stained nucleus and the surrounding background contained in a defined area; (2) the 100 for an adjacent area of similar dimensions, subsequently is subtracted to $y$ ield the IOD of the nucleus. In Section I, DNA measuremerts were made on nuclei of intact whole cells which were fixed, stained and measured while remaining attached to the slides on which they were grown. A large amount of dabris remained on the slides. To diminish debris, MNA measurements in Section Il were determined on cells which were trypsinized from their growing surface, were devoid of their cytoplasm, and were fixed to freshly cleaned slides. The DNA histograns (figure 13) for cultures of all ages sharpenel up, but the age-correlated increase in dispersion persisted.

The last interpretation considered is that aneuploid DNA content may increase in older noncycling cells. Aneuploidy occurs in proliforating cells of aging hI-38 cultures (e.g,, Saksela and Moorhead, 1963). In vivo, aneuploidy also increases with age (e.g., Jacobs et a1., 1963; Crowley and Curtis, 1963). It has been 
postulated that chronosomal abberrations, especially for nondividing cells, could cause aging (Curtis, 1963). If aneuploid DNA content caused cell arrest, the dispersion of DNA values (i.e., the CV) of the 2C and $4 \mathrm{C}$ cells would be greater for old cultures as compared to young cultures, and for nondividilg cells as compared to dividing cells. The $\mathrm{CV}$ could not be calculated because the boundary between $2 \mathrm{C}$ and $4 \mathrm{C}$ cells, and cells in $S$ phase was uncertain. Experiments in Section II were designed to identify $S$ phase cells and permit calculation of the CV.

In conclusion, the existing evidence strongly suggests that the age-associated increased dispersion of DNA values is not due to noncycling $S$ phase cells or to altered stoichiochmetry of the stuining reaction. The possibility that debris is the intrinsic cause of the increased dispersion of DNA values in older cultures is ruled out by the experiments of Section II. These experiments further infer that aneuploid DNA content correlates with culture age.

Figure 21 summarizes the relationships among aging, proliferative capacity and DNA content suggested by this data and by the work of others (Baserga et al., 1971; Cristofalo and Sharf, 1973; Macieira-Coelho and Berumen, 1973). We belive there are two kinds of quiescent (Q) WI-38 cells. The first is exemplified by those cells whose quiescence is induced by density-dependent inhibition of division through various kind; of nutritional depletion. This occurs at any age, and is characterized primarily by its ease of reversibility. These reversibly quiescent cells are referred to as 
Figure 21. The changing relationships of the frequency of proliferating and quiescent cells with culture age. The latter are further divided into reversible (Qr) and appraent nonreversible (Qn) cells, and by DNA content (2C or $4 \mathrm{C})$. The arrows indicate pathways and suggest that the cells transit to the Qn state either directly or via Qr. 

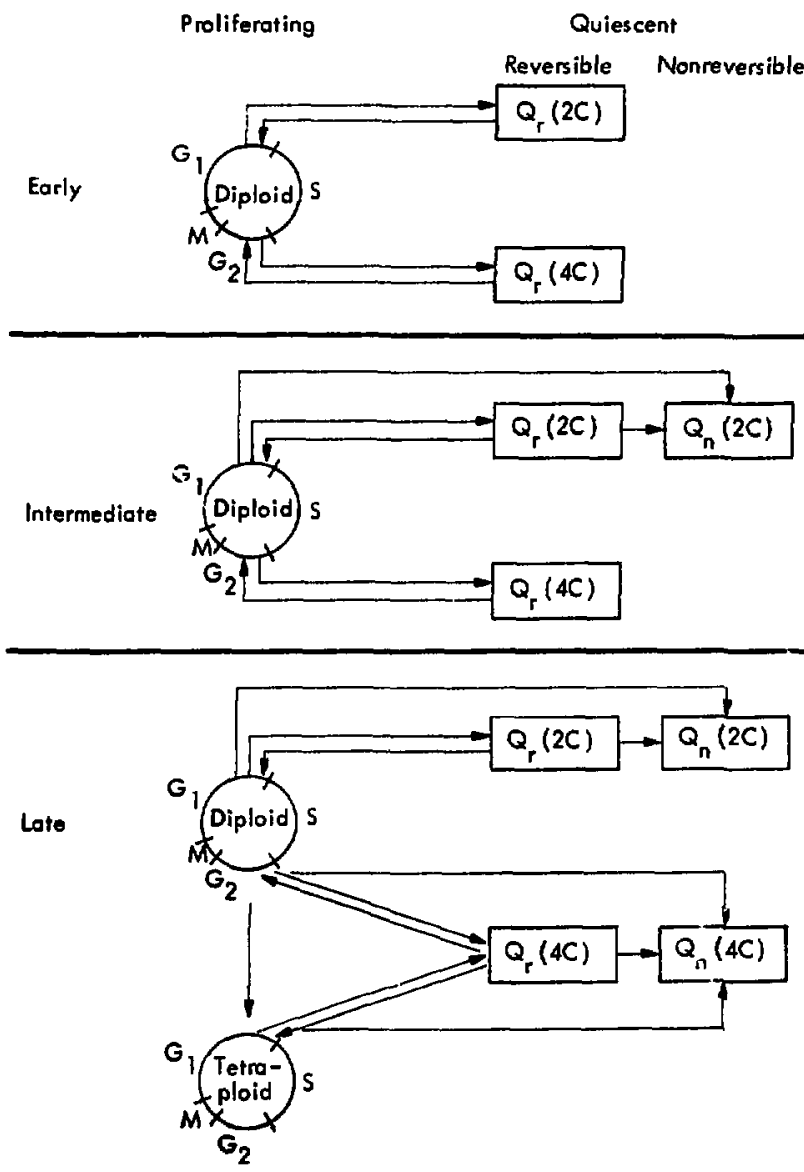

figure 21. 
Qr. The second kind of $Q$ cell cannot be readily reversed, appears to be nonreversibly quiescent and is designated as $\mathrm{Qn}_{\mathrm{n}}$. These, we belive, are the cells that remain unlabeled for 48 hours, that increase in incidence with the age of the culture, and that explain the finiteness of the population. In the aging culture, there is an increased frequency of $2 C$ (diploid $G_{1}$ ) and $4 C$ (either diploid $G_{2}$ or tetraploid $G_{1}$ ) On cells. Although not shown in figure 21, there is also an increase in proliferating and quiescent polyploid (8C) cells.

b. Are "nondividing" WI-38 cells truly out-of-cycle or are they simply cycling slowly?

Recently Macieria-Coelho (1974, 1975) questioned the existence of nondividing WI-38 cells. He cited an experiment which showed that very long ${ }^{3} \mathrm{HdT}-\mathrm{labeling}$ periods (up to 40 days) reduce the percent of unlabeled cells from 34 to 8 . On this basis he concluded that unlabeled cells are a manifestation of the increased length of the average cell cycle and the wide range of cell cycle times in older populations. This is a reasonable alternative to the notion of noncycling cells. We and others (Good, 1974) question, however, whether Macieria-Coelho's experiments adequately support this conclusion. After long labeling periods a docline in the apparent percent of unlabeled cells is, in fact, to be expected. Firstly, at least some unlabeled cells will die without dividing again. Further, all laboled cells which later become quiescent will be misscored as divider:. Finally, the unlabeled fraction of the population will be 
diluted by division of the labeled fraction; for example, if initially $34^{\circ}$ of the total cells are unlabeled, after two divisions the unlabeled fraction would comprise only $11 \%$ of the total. In spite of these considerations, Macieria-Coelho found that after 40 days of ${ }^{3} \mathrm{HdT}$ exposure a substantial fraction ( $8 \%$ ) of the population was unlabeled. This, in fact, supports the notion of nondividing cells. At present, there is no unequivocal way to distinguish cells which are truly out-of-cycle from cells which are cycling very slowly (this is discussed by Mendelsohn, 1962).

In the context of these experiments we have defined a pragmatic point (48 hours) after which a cell is considered nondividing. To determine what fraction of potential dividers are labeled under these conditions, the cell kinetics data of Macieira-Coelho et al. (1966) were reanalyzed by a recently developed automated fitting procedure (Takahashi et al., 1971). The best computer fit showed the average cell cycle time to be 17.4 hours for young WI-38 cells $\left(G_{1}=2.4\right.$ hours, $S=10.5$ hours, $G_{2}=3.3$ hours, $M=1.2$ hours) ald 30.5 hours for old WI -38 cells $\left(G_{1}=14.3\right.$ hours, $S=11.0$ hours, $G_{2}=3.8$ hours, $M=1.5$ hours). The standard deviation of the cell cycle time is 2.8 hours in young eultures, and 10.4 hours in old cultures. Taking this anslysis 1iterally, one would expect all but $1 \%$ of young dividing cells tr. have completed at least one cycle by 24 hours; by 48 hours no stragglers should remain. In old cultures 55 hours is required to comit all but $1 \%$ of the cells to cycle, and approximately $5 \%$ of dividing old cells have not yet finished their first cycle by 48 
hours. Thus, after 48 hours a nonlabeling index of $50 \%$ in old cultures might represent $3 \%$ of tardy dividers and $47 \%$ of cells out of cycle.

This definition of nondividing cells permits a convenient way to quantify the age of the population by the $i I$, since there is a progressive increase in the nondividing fraction of the population with age (Cristofalo and Sharf, 1973). It is an operational definition and it does not imply that all cells defined as nondividing for this specific set of conditions would remain perpetually quiescent. On the other hand, sterility or self destruction of cells must occur or, with time, the slowly cycling cells would uitimately repopulate the culture, and the culture would not have a finite Iife-span; there are no reports to thit effect.

\section{Section II}

In Section I an age-associcted increase in dispersion of DWA values for $2 \mathrm{C}$ and $4 \mathrm{C}$ poaks was indicated. It was hypothesized that this could be due to aneuploid DNA content which could cause cell arrest. This hypothesis was examined in the experiments preserted in Section II. A double labeling cytophotometric-autoradiographic technique permitted quantitation of the dispersion. The results indicated that there was a correlation, but not i causal relationship, for the increased dispersion of DNA values and cell arrest. 
a. Effect of ${ }^{3} \mathrm{HdT}$ on WI-38 cell growth

Preliminary to the cytophutometric experiments, the effect of continuous exposure to varied 1 evels of ${ }^{3}$ HdT on cell growth was examined. The various levels of ${ }^{3} \mathrm{HdT}$ that were tested were used to label dividing cells for all experiments presented in this manuscript. 'The results showed that cellular growth was inhibited by $0.1 \mathrm{\mu Ci} / \mathrm{ml}$ $3_{\mathrm{HdT}}(2.0 \mathrm{Ci} / \mathrm{mM})$ and higher concentrations $(1.0 \mu \mathrm{Ci} / \mathrm{ml}$ or $5.0 \mu \mathrm{Ci} / \mathrm{ml}$, $20.0 \mathrm{Ci} / \mathrm{mM})$, most 1 ikely from radiation damage.

Cytophotonetric-autoradiographic experiments indi.ated that the cells blocked in the diploid $\mathrm{G}_{2}$ or the tetraploid $\mathrm{G}_{1}$ phase.

Cell growth was monitored during continuous exposure to low and high levels of ${ }^{3}$ HdT. Growth was measured by cell number, Coulter volume and L.I.

(1) Labeling with low 1evels of ${ }^{5} \mathrm{HdT}$ Labeling with $0.1 \mu \mathrm{Ci} / \mathrm{ml}^{3} \mathrm{HdT}$ (S.A. $2.0 \mathrm{Ci} / \mathrm{mM}$ )

Uptake of $0.1 \mathrm{Li} / \mathrm{ml}^{3} \mathrm{HdT}$ (S.A. $2.0 \mathrm{Ci} / \mathrm{mM}$ ) at 48 hours of exposure to the label defined dividing cells in cytophotometric-autoradiographic experiments of Section I (Results: $A, 1 a)$. Data in Section II (Results: $A, 2 a(1)$ ) showed that this quantity of ${ }^{3} \mathrm{HdT}$ inhibited cellular proliferation.

At 48 hours of exposure, the LI reached a plateau (figure 3). One would predict that the LI would not plateau but would asymptote toward $100 \%$ as the dividing (1abeled) population increased by proliferation. Cristofalo (Cristofalo and Sharf, 1973; Cristofalo, 1975) considered 
several explanations for the plateau: (1) the presence of cycling cells which synthesized DNA at an undetectable rate; (2) the presence of $\mathrm{G}_{2}$ delayed cells which ultimately entered the proliferating pool; (3) depleted ${ }^{3}$ HdT or depleted essential nutrients; (4) inhibition of cell division by $\mathrm{dT}$; (5) inhibition of cell division by ${ }^{3} \mathrm{H}$ damage. With respect to the first explanation, cycling cells could by autoradiographically detected as unlabeled (noncycling) if, for example, the rate of DNA synthesis is very low. This possibility was considered in the discussion of Section 1 . It is unlikely that unlabeled cycling cells occur at a sufficient frequency to account for the LI plateau.

A similar argument applies to the second alternative, that $G_{2}$ delayed cells enter the proliferating pool. Even if all unlabeled $4 \mathrm{C}$ cells in older populations are delayed in $\mathrm{G}_{2}$, they are quantitatively insufficient (figure 1) to account for the plateau in LI.

The third possibility is that cells did not label due to media depletion. Cristofalo (1975) used conditioned media, which contained $3_{\text {HdT }}$ and which was in contact with cells for 30 to 48 hours, to label another culture. The LI was the same as for a sister culture which was exposed to fresh media. Therefore, the third alternative is exclud 1 .

The fourth possibility is eliminated because the low $\mathrm{dT}$ concentration $\left(5 \times 10^{-5} \mathrm{mN}\right)$ does not inhibit cell division. Populations exposed to media supplemented with $5 \times 10^{-8} \mathrm{M}$ unlabeled $\mathrm{dT}$, 
and to media supplemented with no additional dT had similar growth rates, which were higher than the ${ }^{3} \mathrm{HdT}$-labeled population (Cristofalo, 1975).

The final explanation considered is that the ${ }^{3} \mathbf{H}$ could inhibit cell division. Indeed, figure 2 showed that at 48 hours of labeling, the cell number was significantly lower than for the control (no ${ }^{3} \mathrm{HdT}$ ), and at 72 hours the cell number reached a plateal. Similar results were found by Cristofalo (1975). These results indicate that cell division is inhibited, by radiation damage, which could account for the I.I plateau. Subsequent cell death may also contribute to the LI plateas.

Continuous ${ }^{3} \mathrm{HdT}(0.1 \mu \mathrm{Ci} / \mathrm{ml}, \mathrm{S} . \mathrm{A}, 2.0 \mathrm{Ci} / \mathrm{mM})$ exposure resulted in increased cellular volume. The modal channel number of Coulter volumes (figure 4 and table 1) was greater for cells grown with ${ }^{3} \mathrm{HdT}$ than for cells grown without ${ }^{3}$ HdT. This suggested that some cells block in diploid $G_{2}$ or tetraploid $G_{1}$ and/or had unbalanced growth. The interpretation that ${ }^{3} \mathrm{HdT}$ blocks cells in diploid $\mathrm{G}_{2}$ or tetraploid $G_{1}$ is supported by the cytophotometric-autoradiographic experiments (figure 1) of section I. In comparison to the frequency of labeled $2 \mathrm{C}$ cel1s, older cultures had a disproportionate occurance of 1abeled 4C cells. This may be explained by cells which incorporated ${ }^{3} \mathrm{HdT}$, and as a result of radiation damage subsequently blocked in diploid $G_{2}$ phase. The occurance of labeled $8 \mathrm{C}$ cells suggests that they also may be blocked in tetraploid $G_{1}$ phase. 
Labeling with $0.003 \mu \mathrm{Ci} / \mathrm{mI}^{3} \mathrm{HdT}$ (S.A. $2.0 \mathrm{Ci} / \mathrm{mM}$ )

Uptake of $0.003 \mu \mathrm{Ci} / \mathrm{ml}^{3} \mathrm{HdT}$ (S.A. $2.0 \mathrm{Ci} / \mathrm{mM}$ ) at 4 a hours of exposure to the label, defined dividing cells in

cytophotometric-autoradiographic experiments of Section II (Results: $A, 2 c(1))$. This quantity of ${ }^{3} \mathrm{HdT}$ did not perturb cellular growth (Results: $A, 2 a(1))$.

Cultures grown with $0.003 \mu \mathrm{Ci} / \mathrm{ml}{ }^{3} \mathrm{HdT}$ showed no significant difference in cell number from the control culture (figure 2), regardless of culture age (figures 5,6 and 7). The Coulter volume distribution (figure 4) and modal channel number (table 1) also were similar for the labeled culture and for the control culture. These data showed that cellular growth was not inhibited by continuous exposure to $0.003 \mu \mathrm{Ci} / \mathrm{m} 1{ }^{3} \mathrm{HdT}$ (S.A. $2.0 \mathrm{Ci} / \mathrm{mAj}$ ).

This ${ }^{3} \mathrm{HdT}$ concentration was used in double label cytophotometric-autoradiographic experiments designed to calcula*e the CV of DNA values so that. (1) the growth kinetics of cells which labeled were unperturbed and did not distort the data analysis; (2) cells which incorporated low 1 evels of 3 lidT during continuous exposure were easy to distinguish autoradiographically from cells which were pulse labeled with high concentrations of ${ }^{3}$ lldT.

(2) Labeling with high levels of ${ }^{3} \mathrm{HdT}$ Labeling with $1,0 \mu \mathrm{Ci} / \mathrm{ml} 3^{3} \mathrm{~d}^{\prime \prime} \mathrm{or}$ or $5.0 \mu \mathrm{Ci} / \mathrm{m} 13^{3}$ (S.A. $2.0 \mathrm{Ci} / \mathrm{mN})$ 
Cellular growth was inhibited by continuous exposure to high levels of ${ }^{3} \mathrm{HdT}\left(1.0 \mu \mathrm{Ci} / \mathrm{ml}\right.$ or $\left.5.0 \mu \mathrm{Ci} / \mathrm{ml}^{3} \mathrm{HdT}, \mathrm{S} . \mathrm{A}, 20.0 \mathrm{Ci} / \mathrm{mM}\right)$. Figures 8 and 10 showed that cell division proceeded for approximately the first 24 hours of labeling, and thereafter the cell number remiined constant. At 48 to 72 hours of ${ }^{3} \mathrm{HdT}$ exposure the $\mathrm{LI}$ reached a plateau (figures 9 and 11), which further indicated that cell division was inhibited. Subsequent cell death also may have contributed to the LI plateau.

At 48 hours of ${ }^{3} \mathrm{HdT}$ exposure, cell volume (figure 12, tables 2 and 3) was approximately twice the control volume. Further ${ }^{3}$ HdT exposure resulted in further volume increases. This indicated that cells blocked in diploid $G_{2}$ or tetraploid $G_{1}$, followed by unbalanced growth, or an increase in ploidy level.

An estinate of the maximun radiation dose to cells at 48 hours of exposure to $20.0 \mathrm{Ci} / \mathrm{mM}^{3} \mathrm{HdT}$ is $90 \mathrm{rad} / \mathrm{minute}$ or a total of $260 \mathrm{krad}$ (see Appendix for calculation). This is quite a high dose, which could easjly inhibit cell division and cause cell death.

The effects of acute irradiation on progress through the cell cycle are well documented (see review by Altman et al., 1970). The most striking effect in the first postirradiation cell cycle is a delay in $G_{2}$ phase. Also, there is a delay in $S$ phase, and there is no effect on $M$ or $G_{1}$ phase. The second postirrudiation cell cycle is characterized by a decrease in the percent of dividing cells and an increase in the percent of dead and nondividing cells. With 
increasing time and radiation dose there is an increase in the fraction of cells which grow without division, or so-called giant cells.

Little attention has been given to the formation and fate of radiation-induced giant cells. It is known, however, that they do not exhibit metaphase and telophase figures, and that they synthesize DNA, RNA and protein. This indicates that these cells do not divide and are endoreduplicated or are polyploid.

A likely sequence of events to have curred during exposure to high levels of ${ }^{3}$ HdT is as follows: the cells incorporated ${ }^{3}$ HdT at $S$ phase; most cells proceeded through the first division, as evidenced by cell number (figures $S$ and 10); following a second round of DNA synthesis the cells blocked in $G_{2}$ and, as will be shown in figure 14, have $4 C$ DNA contents; judging from Coulter volume distributions (figure 12, tables 2 and 3) the arrested cells continued to metabolize and grow in volume, Cell death was not followed, but at these doses of radiation one can predict essentially zero survival of clonogenic cells. Further experimentation would be needed to detemine if this is the actual sequence of events of growth inhibition. For the purposes of this discussion it is sufficient to know that these concentrations of ${ }^{3} \mathrm{HdT}$ inhibit division, cause a plateau in the $\mathrm{LI}$ curve, distort DNA histograns, and generally interfere with kinetic analysts. 
b. Effect of different methods of slide preparation on LI

The cytophotometric-autoradiographic experiments of Section I I were designed to quantitatively evaluate the age-correlated increase in dispersion of DNA contents. Debris associated with aging cultures could lead to errors in cytophotometry and thus, increased dispersion of DNA contents. A method of slide preparation which diminished debris was utilized for the cytophotometric-autoradiographic experiments of Section II. The methods of slide preparation used in Sections I and II were compared for their effect on the LI. The Jebris most likely results from lysis of dead cells. To diminish debris, DNA measurements were determined on cells which were trypsinized from their growing surface, were devoid of their cytoplasm, and were fixed to freshly cleaned slides. This method of slide preparation effectively removed the debris, and the DNA histograns (figure 13) for cultures of all ages sharpened up; nevertheless, the age-correlated increase in dispersion persisted.

This method, however, is more harsh than the method of slide preparation used in Section I; in Section I DNA measurements were made on nuclei of intact whole cells whlch were fixed, stained and measured while remaining attached to the slides on whicn they were grown. Selective loss of either dividing or nondividing cells during treatment was tested by measuring the $L I$ of cells treated according to Section I and Section II.

Table 4 shows that nondividing cells were selectively lost when treated by the method of Section II. Although the loss is slight, it 
should be kept in mind in interpretation of the data.

In addition, the method of slide preparation might introduce bias to the data because of the distribution of cells on the slide: for Section I neastrements, cells were distributed in the manner which they grew; for Section II measurements, cells were randomly distributed.

C. DNA distribution of dividing and nondividing WI-38 cells

(1) Double labeling with ${ }^{3} \mathrm{HdT}$

These cytophotometric-autoradiographic experiments were designed to quantitatively evaluate the age-correlated increase in dispersion of DNA contents. One interpretation of the increased dispersion is that it represents aneuploid DNA content which could cause cell arrest. If this hypothesis were true the $\mathrm{Cr}$ of $\mathrm{DNA}$ values would be larger for old cultures than for young cultures, and for nondividing cells than for dividing cells.

Cells were double labeled with ${ }^{3}$ lld to ident ify cycling $\mathrm{G}_{1}$ and $\mathrm{G}_{2}$ cells (by incorporation of lon levels of ${ }^{3}$ HdT after continuous exposure), cells in 5 phase (by incorporation of high levels of ${ }^{3}$ HdT after a pulse), and noncycling cells (by no ${ }^{3}$ idd incorporation). DNA cytophotometry was performed for single, fixed and stained cells, followed by autoradiographic detection of ${ }^{3} \mathrm{HdT}$ uptake for the same cells. The $S$ phase cells were subtracted from the DNA histograms to yield $2 C$ and $A C$ peaks, and the $C C^{\prime}$ of DNA values for the peaks was calculated. 
DNA histograms of figure 13 show progressive changes in DNA content as WI-38 cultures age. The passage 24 culture had a bimodal DNA distribution characteristic of a proliferating diploid population. All cells were cycling. The well defined $2 \mathrm{C}$ and $4 \mathrm{C}$ peaks were diploid $G_{1}$ and $G_{2}$ nuclei and the intervening plateau contained $S$ phase nuclei. As expected, the $2 C$ peak was larger than the $4 C$ peak; each $G_{2}$ cell becomes two $G_{1}$ cells as it passes through the point of division.

The DNA histogram of the passage 55 culture showed age-associated changes in DNA content and proliferative status. The culture was polyploid (8C and $16 \mathrm{C}$ nuclei). Nondividing nuclei with $2 \mathrm{C}$ DNA were blocked in diploid $G_{1}$; nondividing nuclei with 4C DNA were blocked in diploid $G_{2}$ or tetraploid $G_{1}$; nondividing nuclei with $8 C$ DNA were blocked in tetraploid $G_{2}$ or octaploid $G_{1}$. The percent of cycling nuclei in $S$ phase was about $50 \%$ less than for the young culture.

The passage 62 culture showed similar, but more severe ageassociated changes in DNA content and proliferative status, The culture was polyploid. There was a greater fraction of nondividing cells than for the passage 54 culture. Like the passage 54 culture, nondividing cells had $2 \mathrm{C}, 4 \mathrm{C}$ and $8 \mathrm{C}$ DNA contents. The percent of cycling nuclel in $S$ phase was only about $15 \%$ of the $S$ phase nuclei in the young culture.

These data confirmed earlier cytophotometric-autoradiographic findings (figure 1) that with culture age there was an increased frequency of polyploid cells and of nondividing $2 \mathrm{C}, 4 \mathrm{C}$ and $\mathrm{BC}$ cells. In addition, there was a decrease in the fraction of $S$ phase cells. 
The $2 \mathrm{C}$ and $4 \mathrm{C}$ nuclei of the passage 62 culture had a wider dispersion of DNA values than the passage 55 and passage 24 cultures (figure 13). This was particularly evident for the unlabeled $2 \mathrm{C}$ nuclei and the lightly labeled $4 \mathrm{C}$ ruclei; and, these peaks were skewed to the left. Possible explanations for the skewed data are: cells synthesize DNA, but do not have a labeling pattern consistent with being in S phase; (2) cells with aneuploid DNA contents are selected for or against; (3) cells form micronuclei which are subsequently lost during the slide preparation.

The first alternative is compatible with recent evidence which suggests that there is a reduction in the rate of DNA replication in aging human fibroblast cultures (Petes et al., 1974). The rate may be low enough that after autoradiography some cells would appear lightly labeled or unlabeled. This could explain the left skew to the lightly labeled 4C peak. As pointed out in the Discussion of Section I, for young and middle-aged cultures, it is unlikely that a significant fraction of cells would go undetected by the autoradiographic methods employed (Cristofalo and Sharf, 1973; Cristofalo, 1975). Further experimentation is required for very old cultures, and lightly labeled or unlabeled $S$ phase nuclei in the passage 62 culture cannot be completely ruled out with the data at hand.

The second possibility involving aneuploid DNA content is supported by karyotypic analysis which showed aneuploidy and other chromosome aberrations [e.g., fragments or translocations] in 
proliferating cells of aging WI-38 cultures (e.g., Saksela and Moorhead, 1963). The aneuplold cells were predominantly hypodiploid (Saksela and Moorhead, 1963), which would explain the left skew to the unlabeled $2 \mathrm{C}$ and 1 abeled $4 \mathrm{C}$ peaks. The predominance of hypodiploid cells infers that there is a selection mechanism operative; either there is selection for hypodiploid cells or there is selection against hyperdiploid cells.

Further evidence associates aneuploidy and other chromosomal aberrations with the aging process. For example, studies showed that the proportion of aneuploid cells in cultures of human leukocytes increased with age (Jacobs et a1., 1963; Hamerton et a1., 1965). Hypodiploidy, which was more common than hyperdiploidy, was highly correlated with the loss of the $X$ chromosome from female leukocytes and the $Y$ chromosome from male leukocytes. In addition, chromosome and chromatid aberrations were found in the white blood cells of aged persons.

In another study, Crowley and Curtis (1963) scored chromosome aberrations as a function of age in regenerating livers of long-lived and short-lived strains of mice. The development of aberrations was inversely proportional to life expectancy.

Thus, it is reasonable to postulate that one of the effects of aging is a lowering of the mitotic efficiency, leading to lagging of chromosomes or to non-disjunction. This could result in chromosome loss (hypodiploidy) or chromosome duplication (hyperdiploidy). If 
these chromosomes were involved in the control of division the cell could cease to divide.

The final alternative considered is that senescent cells form micronuclei and subsequently lose them during slide preparation. A micronucleus is a small nucleus, separate from and additional to the main nucleus. It is formed by lagging chromosomes or chromosome fragments, during telophase.

Senescent WI-38 cultures have an increased frequency of nuclei with unusual shapes and protrusions, as well as nuclei with one or more relatively small DNA containing vesicles. Figure 22 shows an extreme example of a nucleus with such vesicles. For a future study, it would bo of interest to quantitate the unusual nuclear shapes and structures with culture age.

Micronuclei could be released from association with the main nucleus during the slide preparation method; the cytoplasm was removed in the method used for Section II. The remaining nucleus would be hypodiploid and there would be a left skew to the DNA data (figure 13). In contrast, the slide preparation method used in Section I did not remove the cytoplasm, DNA measurements were made on intact cells, and the data (figure 1) was not ske ed.

other studies presented evidence that atypical nuclear structures, called nuclear blebs, were associated with imparied DNA synthesis and with aneuploidy. For instance, nuclear blebs were induced in the bone marrow cells of patients treated with 5 -fluorouracil, a DNA-inhibiting 
$-120-$

Figure 22. Photomicrograph of an aging KI-38 ce11 with micronuclei. The cell was stained with a $7.5 \%$ Giemsa solution. 


\section{$-221-$}

4

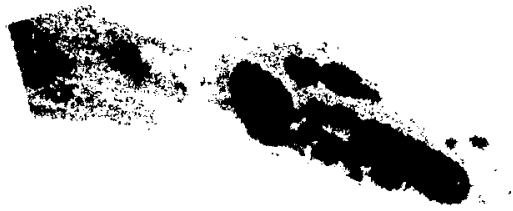


drug (Ahearn et al., 1967). Also, for the bone marrow of leukemic patients there was a positive correlation between nuclear blebs and aneuploidy (Ahearn et al., 1974).

The last two explanations for the skewed DNA data are the most strontly supported alternatives. In fact, it is extremely likely that the two explanations, that is, the occurance of aneuploidy and micronuc: $\$ i$, are directly related; the formation of micronuclei can lead to an aneuploid cell.

For quantitative analysis of the DNA histogram (figure 13), the $S$ phase nuclei were subtracted from the DNA histogram, and the CV of DNA values and the ratio of mean DNA values for the $2 \mathrm{C}$ and the $4 \mathrm{C}$ nuclei were calculated (see table 5).

As shown in table 5, the young culture had very little dispersion of DNA values for $2 \mathrm{C}$ and $\mathrm{AC}$ nuclei. $\mathrm{Also}$, there was precise doubling of mean DNA values for $2 C$ to $4 C$ ruclei. These data suggested that this culture was euploid. Furthermore, these data indicated that the specimen was well bet aved and that there was stoichiometry of staining.

The passage 54 culture had essentially the same CV of DNA values as the young culture. Once again, there was an approximate doubling of mean DNA values for $2 \mathrm{C}$ to $4 \mathrm{C}$ nuclei. Furthermore, nondividing cells had the same mean and $\mathrm{CV}$ of DNA values as dividing cells. These data indicated that the culture wrs euploid. In addition, the specimen was well behaved and there was stoichiometry of staining. 
Furthermore, these data indicated that, for this culture, aneuploidy was not associated with cell arrest.

For the oldest culture, the quantitative changes in dispersion of DNA values are more difficult to interpret. Except for the labeled $2 \mathrm{C}$ nuclei, the passage 62 culture had a CV of DNA values which were more than two fold larger than the passage 55 and passage 24 cultures. The significance of the 1 ncreased $C V$ for the passage 62 culture is uncertain because the $2 C$ and $4 C$ peaks were skewed. Possible explanations for the skewed data were previously discussed.

In sumnary, cytophotometry-autoradiography (figures 1 and 13) revealed that the majority of nondividing cells in aging WI-38 cultures had 2C DNA contents and were in diploid $\mathrm{C}_{1}$ phase. Nondil ding cells also had $4 C$ DNA and were in diploid $G_{2}$ or tetraploid $\mathrm{G}_{1}$ phase. In addition, aging cultures had polyploid ( $8 \mathrm{C}$ and $16 \mathrm{C}$ ) dividing and nondividing cells.

Ruantitative analysis (table 5) of the cytophotometric-autoradlographic data showed that for aging cultures, $G_{1}$ and $G_{2}$ cells had a wider spread of DNA values than for young cultures. The most likely source of the age-associated increased CV of DNA values, is an increased frequency of ancuploid cells and of cells which lost micronuclei during slide preparation. in general, nondividing cells had the same $C V$ of DNA values as dividing cells. litese results suggested that aneuploid DNA content is associated with the aging process, rather than causally related to the loss of proliferative capacity, 
(2) Labeling with high lovels of ${ }^{3} \mathrm{HdT}$

In these cytophotometric-autoradiograrhic experiments the cycle stage was identified for cells which were continuously exposed to high levels of ${ }^{3} \mathrm{HdT}(20.0 \mathrm{Ci} / \mathrm{mM})$. Experiments already discussed showed that cellular growth (figures 8-12, tables 2 and 3) was inhibited at 48 hours ${ }^{3}$ HdT exposure, consistent with a radiation effect. Labeled nuclel ceased cycling after the addition of ${ }^{3} \mathrm{HdT}$, and were termed blocked dividing cells. Unlabeled nuclei ceased cycling before the addition of ${ }^{3} \mathrm{HdT}$, and were termed nondividing cells.

DNA histograms of figure 14 showed that for the young culture all the nuclei were labeled and therefore were blocked dividing. There were no unlabeled or nondividing nuclei. Virtually all of the nuclei had IC DNA; they could be $G_{2}$ diploid or $G_{1}$ tetraploid cells. As previously discussed, a striking effect of radiation is $G_{2}$ delay. These cells markedly increase in volume (figure 12, tables 2 and 3), and could also be radiation-induced giant cells; this is, cells which do not divide and which synthesize DNA, RNA and protein. However, S phase polyploid nuclei would be expected and this did not occur. The young culture had a relatively high frequency (98) of polyploid $8 \mathrm{C}$ nuclei. There were no $S$ phase polyploid nuclei, therefore it is unlikely that ${ }^{3} \mathrm{HldT}$ induced the formation of $8 \mathrm{C}$ nuclel. On the other hand, it is likely that ${ }^{3} \mathrm{HdT}$ blocked $8 \mathrm{C}$ cells and thereby enhanced their frequency, analogous to the way that Colcemld blocks mitotic cells and thereby enhances their frequency. 
The DNA histogram of the labeled nuclei for the old culture is strikingly similar to the young culture. Virtually all of the labeled nuclei had 4C DNA. Also, there were labeled polyploid $8 \mathrm{C}$ and $16 \mathrm{C}$ nuclei. Most unlabeled nuclei had 2C DNA contents and were blocked as diploid $G_{1}$. In addition, there were unlabeled $4 C$ nuclei, which were diploid $G_{2}$ or tetraploid $G_{1}$, and there were unlabeled $8 C$ nuclei, which were tetraploid $G_{2}$ or octaploid $G_{1}$.

In summary, continuous exposure to high levels of ${ }^{3}$ HdT inhibited progression through the cell cycle for young and old cultures. Nuclei which incorporated these high levels of ${ }^{3} \mathrm{HdT}$ had, almost exclusively, 4C DNA. It is likely that these cells accumulated in $G_{2}$ phase consistent with a radiation effect.

\section{B. Premature Chromosome Condensation-Autoradiographic Studies} (Section III)

Premature chromosome studies were utilized (1) to determine whether nondividing cells could condense their chromatin; (2) to determine the stage of the cell cycle in which these cells were arrested; (3) to determine the ploidy level of the nondividing cells.

These studies showed that senescent dividing and nondividing cells were able to condense their chromatin to form PCC. Furthermore, there was no difference in the percent of PCC induced for middle-aged or old WI-38 cultures, i.e, dividing cells appeared to induce as readily as nondividing cells. 
The data in table 7 confirmed the cytophotometric-autoradiographic data (figures 1 and 13) which showed that the subpopulation of noncividing WI-38 cells increased with culture age and that the majority of the: a cells were diploids arrested in $G_{1}$. The cytophotometric data also revealed that with increasing age there was an increased fraction of nondividing cells with $4 \mathrm{C}$ DNA contents, i.e., either $G_{2}$ diploid or $G_{1}$ tetraploid cells. There is some evidence for the existence of a $G_{2}$ delayed subpopulation in aging WI-38 cultures (Macieira-Coelho et al., 1966) as well as in other aging cell systems (Ge1fant and Smith, 1972); however, no unlabeled prematurely condensed chromosomes with typical $\mathrm{G}_{2}$ configurations were observed in this study.

Table 7 further showed that the percentage of nondividing cells induced into PCC and the percentage of nondividing cells present in the parent population did not differ significantly. However, the elimination of $S$ phase cells from this calculation in the PCC population could well be obscuring a deficit of unlabeled cells; hence, there is a possibility that unlabeled $G_{2}$ cells have gone unuetected by this techrique.

For example, the lack of unlabeled $G_{2}$ cells with PCC could be accounted for if $G_{2}$ cells were not induced into PCC with a frequency proportionate to $G_{1}$ cells. Johnson and Rao (1970) reported that in Hela cells $P C C$ was induced more readily in $G_{1}$ nuclei than in $G_{2}$ nuclei. Apparently this was not the case for dividing WI-38 cells in 
culture $A$, since both labeled $G_{1}$ and $G_{2}$ cells with PCC were present in the frequencies expected (table 8). In culture B the total frequency of $\mathrm{G}_{2}$ cells declined in comparison to culture $A$ (table 7). Cytophotometric-autoradiographic evidence (figure 1) indicated that the number of unlabeled $4 \mathrm{C}$ cells present in aging cultures is small. Thus the probability of observing unlabeled $\mathrm{C}_{2}$ cells in these cultures is low. However, the number of unlabeled $G_{1}$ cells induced into PCC was in agreement with the expected values (table 8). There is no reason to expect that unlabeled $G_{2}$ cells would differ unless they were blocked due to a defective mechanism fo: chromosome condensation.

The anomalous PCC configuration shown in figure 20 was observed in three unlabeled cells; approximately 92 chromatids appeared to be homologues paired at the centromere and widely separated along the arms. Two additional unlabeled cells with approximately a diploid number of prematurely condensed chromatids vere paired at the centromere. It is possible that these two cells are, in some unexplained manner, $G_{1}$ diploids or $G_{2}$ haploids. The cells with 92 chromatids may represent arrested $G_{2}$ cells with atypical sister chromatid pairing or tetraploid $G_{1}$ cells with homologue pairing. This PCC homologue configuration is unlike that reported for $G_{2}$ cells by Johnson and Rao (1970) where typically the sister chromatids lie in juxtaposition along their entire length. The mechanism for the pairing that was observed presently eludes explanation. Such an anomalous configuration might be envisioned as a preliminary step to 
endoreduplication. However, since it was observed in nondividing cells only, the pairing phenomenon is more likely the result of a faulty mechanism for chromosome contraction (which may result in a diploid $G_{2}$ block) or the result of an aborted mitosis (which may result in a tetraploid $G_{1}$ block.

In conclusion, all premature chromosome condensations from nondividing cells that were unambiguously classified according to descriptions given by Johnson and Rao (1970) were of the $G_{1}$ type. It is difficult to collect a large number of cells for good statistical analysis, but the technique of PCC proved to be powerful in that it revealed a cell type which heretofore could not be identified, the nondividing $G_{1}$ tetraploid, In addition, the chromosomes of nondividing cells may now be analyzed for structural and numerical aberrations and so provide a useful tool for the investigation of the senescence phenomenon in cell culture.

\section{c. Is Fintte Cellular Life-Span In Vitro Related to Aging In Vivo?}

A salient feature of aging in vivo is the decreased ability to respond to stress or stimuli. One theory of aging is that the decline in adaptability renders the animal more suceptible to death as the result of loss of cellular proliferative capacity. This does not imply that finite cellular life-span is the single causative event responsible for aging. Senescence in vivo is a highly complex and poorly understood process. It involves intercellular and 
intracellular factors, and it involves different kinds of cells, tissues, and organs, as well as various physiological processes. Most likely, the causative events responsible for aging are multiple and interrelated. I will provide evidence that there is a positive correlation between the loss of proliferative capacity and aging, both in vivo and in vitro. Whether this relationship is cause or effect remains unknown.

Tissue culture provides an opportunity to study isolated cells in a controlled environment. This is extremely useful in extricating the factors involved in cellular aging. Of course, it should be kept in mind that these cells are in an artificial environment and that diret: extrapolation from in vitro studies to in vivo aging may be unwarranted. Nevertheless, in vitro studies can yield an immense amourit of knowledge of aging at the cellular level.

Karyotypically normal mammalian cells, regardless of tissue origin, have a finite life.span in vitro. Rare exceptions (e.g., rodent cell cultures, Petursson et a1., 1964; Krooth et al., 1964; and human lymphoblastoid cells, Moore and McLimans, 1968) occur, but the normality of these cells is questionable; for example, human lymphoblastoid cell lines typically contain herpes-type virus (Levy et al., 1968), and minur chromosome anomalies (Huang and Moore, 1969). Immortal cells are karyotypically abnormal and usually have cancer-1ike properties. Paradoxically, this suggests that for mamalian somatic cells to become biologically immortal, they first 
must be induced to the neoplastic state, Human diploid cells in vitro, strain WI-38, have been transformed to immortal heteroploid cells after infection with the tumor virus, $\mathrm{SV}_{40}$ (Giradi et al., 1965). This suggests that the normal diploid karyotype, rather than the artificial environment of tissue culture, places a limit on cellular 1 ife-span.

To date, Hayflick and Moorhead (1961) have presented the most convincing evidence that the finite life-span of human diploid cells in vitro is not due to inadequate nutrition, technical difficulties, toxic metabolic products or microcontaminants. Mixtures of your? and old populations (male and female), distinguishable by karyotypic markers, (Barr bodies) were grown in the same culture vessel. The older population ceased to divide when it reached approximately 50 doublings. The younger population continued to proliferate until it too reached approximately 50 doublings. This indicated that the finite life-span of human diploid cells in vitro is intrinsically controlled.

The loss of proliferative capacity in vitro declines with age in vivo. Hayflick (1965), Goldstein et al. (1969) and Martin et al. (1970) showed a negative regression for the number of population doublings the culture attained as a function of the age of the donor.

In other experiments, colls cultured from patients with progeria or with Werner's syndrome (which are diseases associated with premature aging) showed a striking reduction in proliferative capacity 
(Goldstein et al., 1969; Martin et a1., 1970). For example, skin fibroblasts from a nine year old boy with progeria underwent only two population doublings in vitro. On the othex hand, age matched control cultures were capable of 20-30 population doublings (Goldstein, 1969). Thus, proliferative capacity in vitro reflects both chronological and biological age in vivo.

As mentioned, the aging organism has a decreased response to stress or stimuli. A decreased response to stimulation of cell divisior with age, has been demonstrated for tissues as different as salivary glands (Adelman et al., 1972) and the immune system (W'i 11iamson and Askonas, 1972; Price and Nakinodan, 1972).

Adelman et al., (19:2) administered isoproterenol to various aged rats to initiate a tissue specific burst of DNA synthesis and cell division for salivary glands. From two to at least 24 months of age, the time required to initiate DNA synthesis (measured by $3_{\text {HdT }}$ incorporation) increased linearly. For example, for two month old rats, DNA synthesis initiated at 30 hours after isoproterenol administration, whereas for 12 month old rats DNA symthesis initiated at 42 hours. In addition, there was a marked reduction with age in the magnitude of DNA synthesis and cell proliferation.

The immune system is less responsive to stress or stimuli with age. For instance, older animals are more vulnerable to infections and are more difficult to immunize effectively. The decline in the immune response is related to a decline in proliferative capacity of 
the "bursa"-derived B-cells and the thymus-derived T-cells. The T-cells are antigen specific helper cells which stimulate the B-cells to synthesize antibody.

Williamson and Askonas (1972) indicated that there was a limit to the number of divisions of antibody-forming cell clones under antigenic stimulation. They serially transferred single clones of antibody-producing cells to mic: whose immune systen had been destroyed by heavy irradiation. At each transfer, antigen was injected and clonal activity was recognized by the production of characteristic antibody. Continuing serial transfer showed a loss of antibody production, which indicated that the antibody-producing cell clones had a finite life-span.

By measuring the amount of antigen necessary for maximum antibody production, Price and Makinodan (1972) determined that the immune response declined by about 10 fold in old mice, when conpared to young mice. The kinetic details from such dose-response experiments further indicated that this effect was due to a marked decline in proliferative capacity of $T$ - and $B-c e l 1 s$ from old mice.

Serial transplanation experiments gave additional evidence that cells in vivo have decreased proliferative capacity with age. These experiments also approached the question of whether the loss of proliferative capacity is truly intrinsic to the cell, or is dependent on enviromental influences of the old anima1. Designated somatic tissues were serially transplanted into new, young, inbred hosts each time the recipient approached old age. In general, normal somatic 
cells (e.g., hematopoietic cells, Siminovitch et al., 1964 and Cudkowicz et al., 1964; mammary cells, Daniel, 1972) serialıy transplanted to young hosts clearly showed a decline in proliferative capacity with cell age. This indicated that the loss of proliferative capacity is intrinsic to the cell.

of these studies, the most comprehensive serial transplantation study was of mouse mammary tissue (Daniel, 1972). Mamnary tissue was transplanted to inguinal fat pads of three week old mice, from which the mammary rudiment was surgically excised. Primary transplants grew for two to three months, until they filled the fat pad. With serial transplantation of the mammary tissue there was an approximately linear decline in growth potential, measured as the percentage of the fat pad filled in a fixed time interval (Daniel et al., 1968). This decline in growth potential could not be due to the trauma of subcultivation because the number of successful transplants did not decline with increasing subcultivation.

In contrast, precancerous mouse mammary cells, transformed spontaneously or by chemicals, showed unlimited growth potential when serially transplanted in vivo (Daniel et al., 1975). This contrast parallels the finite life-span of normal diploid WI-38 cells and the unlimited growth poiential of $\mathrm{SV}_{40}$ transformed WI-38 cells.

Further studies of mouse mamnary tissue presented more evidence for intrinsic control of proliferation capacity (Daniel and Young, 1971). As mentioned, a primary transplant of mammary tissue, fills 
the fat pad in approximately two to three months. Subsequently growth ceases, but the cells still metabolize. Mamnary tissue was transplanted at two subcultivation intervals. One line was transplanted at three month intervals, and the tissue proliferated almost continuously. The other line was transplanted at 12 month intervals. During most of the 12 month interval the tissue was metabolically active and did not proliferate. The tissue transplanted at three month intervals decliner more rapidly in growth potential than the tissue transplanted at 12 month intervals. This indicated that proliferative potential is intrinsically controlled, since the number of cell divisions, rather than the passage of "metabolic" or calendar time, places the limit upon cellular life-span.

Further support for these concepts came from a different approach (Daniel and Young, 1971). Ductal outgrowths arising from mammary transplants proliferate by apical addition; the center of growth expernences relatively few divisions, whereas the periphery of the outgrowth is the site of intense mitotic activity. Two transplants lines, one from the center of the outgrowth and the other from the periphery, were serially propagated. The transplant from the periphery of the outgrowth, which had more cumulative cell divisions, declined more rapjdly in growth potential than the transplant from the center of the outgrowth. This is further proof that there is a cellulax program which places an ultimate limit on the possible number of cell divisions in vivo, and hence on cellular life-span. 
This concept is supported by comparable data obtained in vitro (De11' Orco et al., 1974; Dell' Orco, 1974). WI-38 cells were maintained in a metabolically active, nonmitotic state by reducing the serum concentration of the growh medium from $10 \%$ to $0.5 \%$. At various time periods, the nonmitotic cells were returned to the proliferating state by subcultivation with growth medium containing $10 \%$ serum. These cells were capable of an equivalent number of cell divisions, in a proportionately longer calendar time, as controls that had been continuously cultured on growth medium. Thus, the number of divisions, and not the "metabolic" or calendar time, places the limit upon cellular life-span.

In summary, these experiments showed that with age there is a loss of proliferative capacity in vitro and in vivo. Furthermore, the loss of proliferative capacity appears to be intrinsically controlled. The role of specific $t$ issues in this phenomenon will now be discussed.

\section{Loss of Proliferative Capacity for Different Tissue Types}

Senescence in vivo is a complex process which involves different tissue types. In terms of proliferative capacity, Nessier and Leblond (1960) designated adult mannalian tissues as renewing, expanding, or static, according to whether they undergo cell division to replenish lost cells, resort to mitosis only to augment a population of permanent cells, or lack the capacity of mitosis altogether. I will provide evidence that with age, there is a decline of proliferative capacity or of cell number for all types of tissue. 
Interpretation of the literature in this area is complicated by several factors: 1. The literature is scarce and few studies are well documented. 2. All tissues within a specific classification (e.g., renewing tissue) did not exhibit a decline of proliferative capacicy or of cell number with age. 3. Some tissues (e.g., nervous tissue) declined in proliferative capacity or in cell number for some animals and not others. Of course, the last two factors do not discredit age-correlated proliferative 10ss. Some authors (e.g., Kohn, 1975), however, have rejected aging theories which involve loss of proliferative capacity because of the negative examples. Nevertheless, even a conservative assessment of the existing literature clearly indicates that there is a loss of proliferative capacity and cell number for some cells in all tissue types 1. Renowing tissue

Renewing tissues (e.g., intestinal and skin epithelium, hematopoietic tissues) have a proliferating compartment of immature stem cells which gives rise to nonproliferating differentiated cells. With time, the differentlated cells die. The stem cells replenish the dead cells and maintain the population in a steady state.

The population dymamics of WI-3B cells are most similar to renewing tissues in vivo. The major difference is that WI-38 cells are without in vivo feedback controls and are subcultivated repeatedly; hence, they continuously proifferate rather than maintain a steady state. 
With age, the stem cells of som renewing tissues (see below) have an increased cell cycle time and the number of stem cells declines. Decline in cell renewal would seem to lead to impaired tissue function and a decreased response to stress or stimuli. There is not a complete lass of proliferative activity as with WI-33 cells. This may be because cells in vivo are under homeostatic controls and do not realize their full potential for division and, therefore, age slower. This implies that if an organism lived long enough, the stem cells of renewing tissues would hive a complete loss of proliferative capacity.

Few studies exist for humans but there are numerous animal studies showing a decline in proliferative capacity with age for various renewing tissues (see review by Buetow, 1971, and Gelfant and Smith, 1972). The mouse was ihe must extensively studied animal. Cell cycle kinetics of mouse tissues that were examined showed that virtually all renewing tissues had an increased cell cycle time, primarily due to lengthening of the $G_{1}$ phase. In addition, there was a decreased number of cells in the proliferating compartment. Examples of mouse tissues that were examined are: crypt cells of the colon (Thrasher, 1971) and of the duodenum (Lecher and Sacher, 1968); the esojhogeal ephithelium (Thrasher, 1971); the epidermi: of the ear and hindpaw (Cameron, 1972); the epithelium on the ventral surface of the tongue (Cameron, 1972). Ear spidermis also had a progressive increase of noncycling $\mathrm{C}_{2}$-blocked cells, from $2.5 \%$ for two week old mice to $12.0 \%$ for 30 month old mice (Pederson and (selfant, 1960). 
As discussed previously, there is a decline in the immune response with age. In addition to the studies mentioned (Williamson and Askonas, 1972; Price and Makinodan, 1972), Davin and coworkers (1971) showed that there was a progressive decline of functional sten cells of mouse bone marrow from middle-age to death. Quantitation of functional stem cells was determined by the ability of bone marrow to give rise to spleen modules of hemopoiesis when transplanted into lethally irradiated, young adult, syngeneic recipients.

2. Expanding tissue

Expanding tissue (e.g., liver tissue, kidney tissue, many endocrine and exocrine $t$ issues) primarily consists of $G_{D}$ cells; typically the cells are nonproliferating, but the retain the capacity for division. Such $C_{0}$ cells in expanding tissues are long-lived and turnover slowly, whereas the bulk of parenchymal cells of renewing tissues are short-lived and are constantly being replaced.

Some investigators (e.g., Curtis, 1963) have proposed that the aging phenomenon is most likely caused by loss of functional capacity of organs contairing cells which cither rarely divide (expanding tissue) or are incapable of division (static tissue), since the defective cells will be retained indefinitely.

Liver is readily induced to proliferate after partial hepatectomy. Marshak and Byron (1945) found that age increasingly delayed the initlation of mitosis in regenerating 1 iver. Bucher and her coworkers (1964) discovered that the increasing delay in mitosis was related to an increasing delay in the initiation of DNA synthesis. For weanling 
rats, the rate of DNA synthesis reached a peak approximately 21 hours after partial hepatectomy. Young adults (4 nonths old) had maximum synthesis 3 hours later than the keanlings, and older rats (12-15 months) lagged $B$ to 12 hours behind the weanlings. At 40 to 50 hours there was no difference in DNA synthesis for old rats and young adults. Hith age, there was also a loss of synchrony of DNA synthesis. These results showed that the initial proliferative response after hepatectomy was progressively delayed with increasing age.

For the kidney, the only way growth can occur is by increasing the lengths and diameters of nephrons. This involves both hypertrophy and hyperplasia of the tubular cells. Unilateral nephrectomy stimulates hypertroghy and hyperplasia in cells of the proximal convoluted tubules of the remaining kidney. MeCreight and Sulkin (1959) showed that for control and nephrectomized rats, the Maried inversely with age. Control senile (38 month old) rats had it three fold lower MI than control young ( 4 month old) rats. Nephrectomized senile rats had a five fold lower $M I$ than nephrectomized young rats.

The lung is an organ capable of partial growth. To some degree, the ability to form new functional units, or alveoli, persists into adult life, but this ability disappears with age. In compensatory hypertrophy following removal of lung tissue there some evidence for new alveolar formation in young animals. In contrast, older animals simply showed dilatation of the existing functional units (Bremer, 
1937; Longacre et al., 1940). It is probable that the decline in the capacity of older animals to develop new alveoli would restrict their ability to respond to increased respiratory demand.

\section{Static tissue}

Static tissues (e.g., nervous tissue, striated muscle fibers) are so fully differentiated, they can no longer divide. The cells have the potential to live as long as the organism survives. However, cells which are lost are irreplacable and loss of essential cells may render the animal susceptible to death.

There are nunerous reports of an age-correlated decline in the number of nerve cells and fibers for humans, but only a few reports for other animals (see review by Buetow, 1971). For example, with age there is a marked loss of cells from the superior temporal gyrus and the post central gyrus of the human cerebral cortex (Brody, 1955). Further documentation of these experiments by new counting techniques would be desired, because there are wide variations in the number of nerve cells and of fibers under normal conditious.

The regeneration of nerve fibers declines with age. Drahota and Gutmann (1961) showed that thore was marked delay in axonal growth of crushed motor nerves for old xats. Loss of nerve cells or decline in regenerative ability could clearly lead to decreased responsiveness for the aging organism.

In swmary, for some cells of all tissue types there is a positive correlation for loss of proliferative capacity with age. It is 
important to remember that biochemical, vascular and other physiological decrements which occur well before loss of proliferative capacity, could be the salient variables that cause aging. Clearly, further experimentation is required to determine whether proliferative loss is an etiological or a pathogenic factor of aging in vivo.

\section{E. Possible Mechanisms of Finite Cellular Life-Span In Vitro}

There are two basic schools of thought, programmed senescence and random senescence, to account for the finite proliferative capacity of cells in vitro. The first school of thought infers that there is a program or a "biological clock" with a fixed number of cell divisions. The second school of thought infers that the accumulation of damage from random events 1 imits cellular life-span.

From the two schools of thought, branch a myriad of aging hypothesis, tantamount to a review of contempory molecular biology. For this discussion it would not be feasible, nor appropriate, to review the literature on aging theories. I will briefly discuss the most popular theory of each school of thought; (1) that there is a genetic program with a fixed number of cell divisions (programed senescence) (llayfljck and Moorhead, 1961; Hayflick, 1965), (2) that randon errors in protoin synthesis lead to, after many divisions, a letha] "orror catastrophy" (randon senescence) (Orgel, 1963). Propramed senescence. Since different species have characteristic and inheritible life-spans, it follows that aging is urder genetic 
control. At the cellular level there is some evidence for a positive correlation between the mean life-span of a species and the number of population doublings the embryonic fibroblasts can attain in vitro (Hayflick, 1975).

Programmed cell death is the usual method of eliminating organs and tissues that are useful only in the larval or embryonic stages of many animals, including mamals [e.g., the pronephros and mesonephros of higher vertebrates, the tail and gills of tadpoles, and larval insect organs (Saunders, 1966)]. A similar kind of programmed cell death may explain aging in vitro.

Numerous well documented experiments al ready described support the theory that cellular life-span is programed. These experiments provided ovidence that the life-span of diploid cells is related to the number of cell divisions rather than to chronological time (e.g. Hayflick and Moorhead, 1961; Hayflick, 1965; Daniel et al., 1968; Danie1, 1972; Daniel and Young, 1971; Dell'Orco et al., 1974; Del1'Orco, 1974).

Rundon senescence. In 1963, Orgel proposed the "error catastrophe" thoory for collular aging. He suggested that random mistakes in amino acid soquences of proteins, especially enzymes concerned with the processing of gunetic inforwation (e.g., polymerases), will result in further aistakes in protein synthesis. Consequently, there is a self-propegating accunulation of errors which leads to cellular deterioration and death. Recently, the original theory was modicied 
to include the possibility that DNA damage also may account for the initial error frequency (llolliday and Tarr: , 1972; Orgel, 1973).

The error theory is supported by experiments which slowed that certain environmental treatments altered the life-span of diploid cells. Fetal lung fibroblasts, strain MRC-5, were grown at $40^{\circ} \mathrm{C}$. The growth rate was normal, nevertheless, there was a $50^{\circ}$ reduction in. 1 ife-span (Thompson and Holliday, 1973). Shifting the cultures to $37^{\circ} \mathrm{C}$ did not lead to recovery. In another experiment (Iolliday and 'Tarrant, 1972), MCR-5 cel1s kert grown in nontoxic concentrations of S-fluorouracjl, which incorporates into $\mathrm{xNA}$ and reduces the fidelity of transcription and/or translation. These cultures also had i significant ly shortened 1 ife-span.

Chronic administration of low doses of ionizing irradiation shortened the Iife-span of chick cmbryo fibroblasts in vitro (Lima et al. 1972) and shole animals (sce review by Curtis, 196.3). It has heen suggested that irradiation induced cliromosomal aberrations and accelerates the accumulation of errors. The interpretation of such experiments, however, is complicated by accompinying disease due to radiation. In addition, shortening the life-span by environmental treatments does not prove the error theory; suth treatments also may damage the slock mechanism.

The ertor atastrophe theory is further supposted by experiments which showe that certain proteins glucose-6-phosphate dehydrogenase and 6-phosphogluconate dehydrogenase (llolliday and Tarrant, 1972), and lact ic dehydrogenase (lewis ard Tarrant, $19^{7}-\gamma^{7}$ here altered in aging 
MRC-5 cultures. These data further showed a decreased enzyme specificity in aging cultures, However, this does not establish that protein synthesis is inaccurate. It also could reflect accumulation of post-syntheticaly modified proteins in old cells.

A major prediction of the error theory has not been fulfilled; viruses grew in senescent WI-38 cells as effoctively as in young cells, and they did not contain defective proteins or have an increased frequency of mutations (Holland et al., 1973; Tonkins et al. 1974). Viruses use the cells own wachinery for synthesizing proteins, therefore these experinents infored that old cells meintainod accuracy of their protein synthosizing machinory.

Rocontly, Ryan ot a1. (1974) also presented ovidence against the error thuory. WI-38 cells grown in the presence of nontoxic concentrations of anino acid analogs, p-fluorophenylalanine and othionine, had a lifo-span sinilar to the control. Higher concentrations did inhibit prollferation, but if the cells were placed in frash analog froe mediun, they rocovered and achioved the sane nubar of population doublings as the control.

Clenrly further studies are needed before of ther programed senescence or random sonescence can be proved or dispioved. I believo that the oxisting ovidence is in favor of programed aging, but I also believe that further experinentetion will prove that the two schools of thought are inextricably interdependent. 
F. A Profile of the Nondividing Cell in Aging liI-38 Cultures

Knowledge of the biochemistry and etiology of nondividing cells in aging human diploid cultures is nearly nonexistent. The existing biochemical information (see review by Cristofalo, 1972) for mass populations of aging l'I-38 cultures cannot be directly applied to nondividing cells, since the cultures are "mixed populations" which contain dividing and nondividing cells. The approach utilized in this investigation does allow one to study nondividing cells directly. The only other individual cell study reported (Deamer and Gonzales, 1974) showed that nondividing cells accunulate lysosomes containing "age pigment" or "lipofuchsin".

Individua! cell studies jeported in this disscrtation defined the following properties of nondividing cells: (1) niploid and tetraploid cells cease to cycle in the $G_{1}$ phase. (2) Most nondividing cells are liploid. (3) With age, there is an increased frequency of nondividing cells with polyploid (tetraploid) and aneuplois DNA contents. (4) Most likely, measurable aneuploidy does not cuuse cell arrest. (5) londividing cells have the capacity to condense their ihromat in and form chromosomes as readily as dividing cells, (6) The chromosomes of some nondividing cells in aging rultures have anomalous shromosome configurations; chromatids show apparent homologous pairing at the centromere regions and exhiblt wide separation along the arms.

The work presented in this dissertation was undertaken to identify the cell cycle phase of nondividing aging human cells in culture. 
$-146-$

Biophysical and cytological techniques were utilized, in combination, or individual cells. The results show that nondividing cells, diploid or tetraploid, are in the $G_{1}$ phase. This is a step in the expansion of our understanding of the senescence phenomenon in cell culture. 
CONCLUSIONS

Cytophotometric-Autoradiographic Studies, Section I

(1) Nith age, there is a progressive increase in nondividing WI- 38 cells relative to dividing cells.

(2) The majority of nondividing cells have $2 \mathrm{C}$ DNA contents and ther fore are arrested in diploid. se.

(3) Nondividing $4 C$ cells appear increasingly with the age of the culture. These may be cells arrested in diploid $\mathrm{G}_{2}$ or tetraploid $G_{1}$ phase.

(4) The frequency of dividing and nondividing polyploid (SC) cells increases rith culture age.

(5) Older cultures have a wider dispersion of DNA values than younger cultures.

Cytophotometric-Autoradiographic Studies, Section Il

(1) Continuous exposure to high levels of ${ }^{3}$ HdT inhibits KI-38 cell cycle traverse: the cell number and LI curves reach a plateau; the cell volume increases; the cells accumulate with $4 C$ DN ontents and it is likely that they olnck in $\mathrm{C}_{2}$ phase. This patter $s$ cousistent with a radiation effect.

(2) Cytophotometric-iutoradiographic experiments using doulle labeling to identify $s$ phase cells, confirm the age-correlited observations of Section I: there is a progressive increase in the 
frequency of nondividing cells, which predominate in the diploid $G_{1}$ phase; there is an increased frequency of nondividing $4 \mathrm{C}$ cells; there is an increased frequency of dividing and nondividing polyploid (8C and $16 \mathrm{C}$ ) cells. In addition, there is a decrease in the fraction of $S$ phase cells.

(3) These double label cytophotometric-autoradiographic experiments also permit quantitation of the dispersion of DNA values. These duta show that the $C V$ of DNA values for $2 C$ and $A C$ cells increases with age, and, in general, that the CV of DNA values is similar for dividing and nondividing cells. Thus, there is a positive correlation with increased $C V$ of DNA values and cell age. Furthermore, 1t appears that there is not a causal relationship for moasurable CV of DNA values and cell arrest. The increased CV of DNA values ts consistent with the interprotation that there is an increased frequency of anouploid dividing and nondividing colls in aging cultures,

Premature Chromosome Condensation-Autoradiographic Studies, Section III

(1) Nondividing WI-38 cells appear to condense their chromatin to form PCC as readily as dividing cells.

(2) The efficiency of PCC induction is independent of phase in the cell cycle $\left(G_{1}\right.$ or $G_{2}$ ) as shown by comparison of observed frequencies with expected frequences for niddle-aged cultures.

(3) Ninety-six percent of the nondividing cells, diploid or tetraploid, induced into PCC have single chromatids and are therefore 
blocked in the $r_{1}$ phase.

(4) The remaining $t^{\circ}$ of the nondividing cells have anomalous PCC configurations; chromatids show apparent homologous pairing at the centromere regions and exhibit wide separation along the arms. These may be $G_{2}$ cells with atypical sister chromatid pairing or $G_{1}$ cells with homologue pairing.

(5) Typical $\mathrm{C}_{2}$ configurations (double chromatids which pair along the entire arm length) werc observed only among dividing cells. (6) These data indicate that nondividing cells with 4C. DNA contents shown in the cytophotonetric-nutoradiographic experiments of Sections I and II are arrested in tetraploid $c_{1}$ phase, rather than in diploid $G_{2}$ phase. 
AFPENDIX

Calculation of Dose (Rad/CeIl) from ${ }^{3} \mathrm{HdT}$

Cleaver and his coworkers (1972 and personal communication) have calculated the equivalent dose of $\mathrm{rad} / \mathrm{cell}$ from ${ }^{3} \mathrm{HdT}$ incorporation:

Assume that the diploid DNA content is approximately $6 \times 10^{-6} \mathrm{\mu g} /$ ce11, therefore, in exponential gorwth the average DNA content is $9 \times 10^{-6} \mu \mathrm{g} / \mathrm{cell}$; and that the number of thymines per cell in exponential growth is approximately $3.6 \times 10^{9} \mathrm{t} / \mathrm{cell}$.

Let the S.A. of the thymidine supplied equal $\mathrm{S} \mathrm{Ci} / \mathrm{mM}$. Since 30 $\mathrm{Ci} / \mathrm{mH}^{\mathrm{H}}$ equals ${ }^{3}{ }^{3} \mathrm{H}$ atom/thymidine, then the number of ${ }^{3} \mathrm{H}$ atoms per thymidine molecule is $[S / 30)^{3} \mathrm{H} / \mathrm{T}$.

If all the DNA thymidinn comes from exogenuusly supplied thymidine $[1, e .$, when the concentration of thymidine in the mediun exceeds approximately $10^{-6} \mathrm{M}$ ), then after one cycle of DNA replication (one strend substitution) the number of ${ }^{3} \mathbf{f l}$ atoms per cell is $\left(3.6 \times 10^{9} / 2\right) t / c e 11 \cdot[S / 30)^{3} \mathrm{H} / \mathrm{T}$ $=65 \times 10^{7} 3_{\mathrm{H} / \mathrm{col} 11}$ 
The ${ }^{3} H$ decay rate is $10^{-7}$ per ${ }^{3} \mathrm{H}$ atom per minute, therefore the decay rate in cells labeled with ${ }^{3} \mathrm{HdT}$ is $65 \mathrm{dpm} / \mathrm{cell}$. One ${ }^{3} \mathrm{H}$, decay is equivalent to $0.5 \mathrm{rad} x$-rays (Cleaver et al., 1972) therefore the dose rate delivered to cells equals $35 \mathrm{rad} / \mathrm{min}$.

After two cell cycles (one and onc-half strand substitution) the dose rate delivered to the cells is $4.5(\mathrm{~S}) \mathrm{rad} / \mathrm{min}$. Thus, at 48 hours of exposure to $20 \mathrm{Ci} / \mathrm{mM}$ " $\mathrm{HId}$ the dose rate is $90 \mathrm{rad} / \mathrm{min}$. This dose rate may be an overestimate, since the thymidine concentration approximately equals $0.2 \times 10^{-6} \mathrm{M}$, and it is estimated that all the DNA thymidine comes from exogeneously supplied thymidine when the concentration exceeds approximately $10^{-6} \mathrm{M}$.

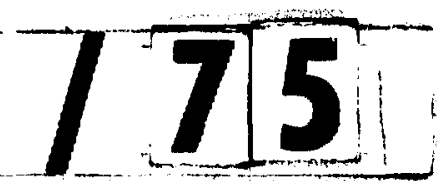

